\title{
Site Environmental Report for Calendar Year 1998 DOE Operations at Rocketdyne Propulsion \& Power RD99-115
}

\author{
Prepared by the Staff of \\ Rocketdyne Propulsion \& Power \\ Edited by P. D. Rutherford
}

September 22, 1999 


\section{DISCLAIMER}

This report was prepared as an account of work sponsored by an agency of the United States Government. Neither the United States Government nor any agency thereof, nor any of their employees, make any warranty, express or implied, or assumes any legal liability or responsibility for the accuracy, completeness, or usefulness of any information, apparatus, product, or process disclosed, or represents that its use would not infringe privately owned rights. Reference herein to any specific commercial product, process, or service by trade name, trademark, manufacturer, or otherwise does not necessarily constitute or imply its endorsement, recommendation, or favoring by the United States Government or any agency thereof. The views and opinions of authors expressed herein do not necessarily state or reflect those of the United States Government or any agency thereof. 


\section{DISCLAIMER}

Portions of this document may be illegible in electronic image products. Images are produced from the best available original document. 


\section{Site Environmental Report Reader Survey}

To Our Readers:

The Annual Site Environmental Report publishes the results of environmental monitoring in support of DOE-sponsored programs at Rocketdyne's Santa Susana Field Laboratory and De Soto sites, and documents our compliance with federal, state, and local environmental regulations. In providing this information, our goal is to give our readership-regulators, scientists, and the public - a clear understanding of our environmental activities, the methods we use, how we can be sure our results are accurate, the status of our programs, and significant issues affecting our programs.

It is important that the information we provide is easily understood, of interest, and communicates Rocketdyne's efforts to protect human health and minimize our impact on the environment. We would like to know from you whether we are successful in achieving these goals. Your comments are appreciated and will help us to improve our communications.

1. Is the writing

$\square$ too concise?

$\square$ too wordy?

$\square$ uneven?

$\square$ just right?

2. Is the technical content

$\square$ too concise?

too wordy?

$\square$ uneven?

$\square$ just right?

3. Is the text easy to understand?

$\square$ yes $\square$ no

If you selected "no," is it:

$\square$ too technical $\square$ too detailed

$\square$ other:

4. Is the report comprehensive?

Yes No

(please identify issues you believe are missing in the comments section)

5. Do the illustrations help you understand the text better?

Are the figures understandable?

Are there enough?

Too few?

Too many?

6. Are the data tables of interest?

Would you prefer short summaries of data trends instead?

7. Is the background information sufficient?

Are the methodologies described reasonably understandable?

8. Are the glossaries and appendices useful?

Other comments:

Please return this survey to Radiation Safety - M/S T487, The Boeing Company, Rocketdyne Propulsion \& Power, 6633 Canoga Avenue, Canoga Park, CA 91309.

OPTIONAL INFORMATION

Name: Occupation:

Address: 


\section{CERTIFICATE OF ACCURACY}

I certify that I have personally examined and am familiar with the information submitted herein and, based on inquiry of those individuals immediately responsible for preparing this report, I believe that the submitted information is true, accurate, and complete.

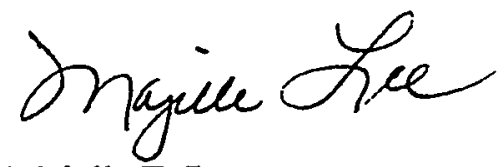

Majelle E. Lee

Program Manager

DOE Site Closure

Rocketdyne Propulsion \& Power

September 22, 1999 


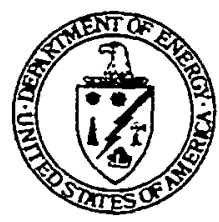

\author{
Department of Energy \\ Oakland Operations Office \\ 1301 Clay Street \\ Oakland, California 94612-5208
}

September 22, 1999

Distribution:

SUBJECT: 1998 Environmental Report (SER) for the Energy Technology Engineering Center (ETEC)

This report is prepared by the Boeing Company, Rocketdyne Propulsion and Power for the U.S. Department of Energy (US DOE). It is a comprehensive summary of the Department's environmental protection activities at ETEC in Canoga Park, California for Calendar Year 1998. SERs are prepared annually for all DOE sites with significant environmental activities and distributed to relevant external regulatory agencies and other interested organizations or individuals.

To the best of my knowledge, this report accurately summarizes the results of the 1998 environmental monitoring and restoration program at ETEC for the DOE. This statement is based on a review by the DOE Oakland staff, a Boeing review, and the quality assurance protocols applied to monitoring and data analysis at ETEC.

A reader survey form is provided with the SER to provide comments or suggestions. Write directly to the above address. Questions may also be directed to Philip Boehme, U.S. Department of Energy, ETEC Site Office, at (818) 586-5571.

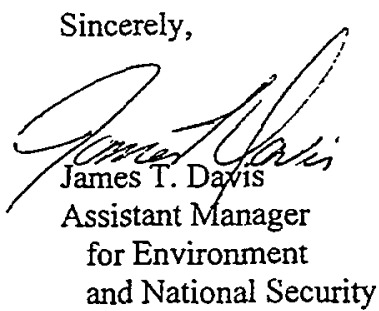




\section{CONTENTS}

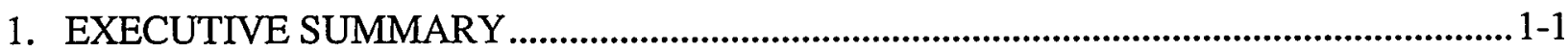

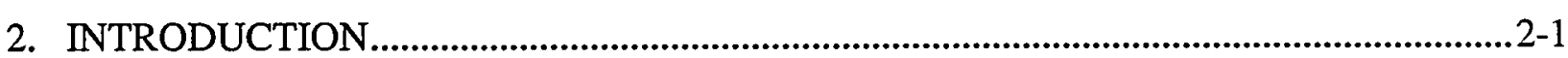

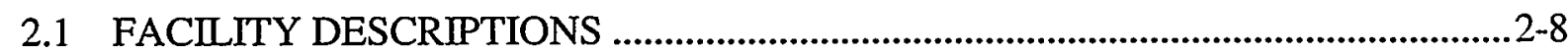

2.1.1 Santa Susana Field Laboratory Site .......................................................................2-8

2.1.2 De Soto Site........................................................................................... 2-11

3. COMPLIANCE SUMMARY …….................................................................................

3.1 COMPLIANCE STATUS .......................................................................................

3.1.1 Radiological ...........................................................................................

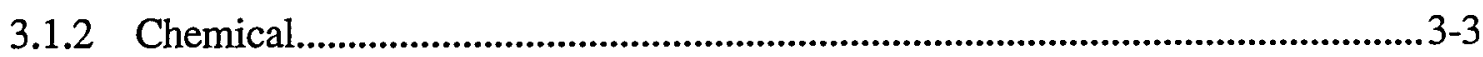

3.1.3 Public Participation ...................................................................................

3.1.4 1998 Agency Inspections/Audits ....................................................................3-8

3.2 CURRENT ISSUES AND ACTIONS ......................................................................

3.2.1 Progress in Decommissioning Operations ..............................................................3-9

3.2.2 Resource Conservation and Recovery Act.......................................................3-13

3.2.3 Permits and Licenses (Area IV) ...............................................................

4. ENVIRONMENTAL PROGRAM INFORMATION .......................................................4-1

4.1 ROCKETDYNE ENVIRONMENTAL PROTECTION AND REMEDIATION.........4-1

4.2 ENVIRONMENTAL MONITORING PROGRAM.................................................4-3

4.2.1 Radiological Monitoring ..............................................................................4-4

4.2.2 Non-Radiological Monitoring ............................................................................4-4

4.3 ENVIRONMENTAL TRAINING ......................................................................

4.4 WASTE MINIMIZATION AND POLLUTION PREVENTION ..................................4-5

4.4.1 Program Planning and Development............................................................... 4-5

4.4.2 Training and Awareness Programs ....................................................................4-6

4.4.3 Waste Minimization and Pollution Prevention Activities...................................4-7

4.4.4 Tracking and Reporting System ...........................................................................4-8

5. ENVIRONMENTAL RADIOLOGICAL MONITORING ....................................................5-1

5.1 DOE FACILITIES AT SSFL (AREA IV) ….....................................................

5.1.1 Direct Radiation ..........................................................................................

5.1.2 Airborne Radioactivity.............................................................................5-5

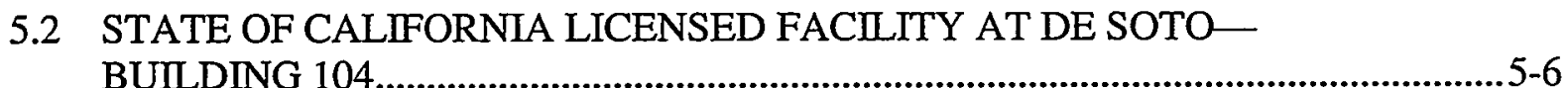

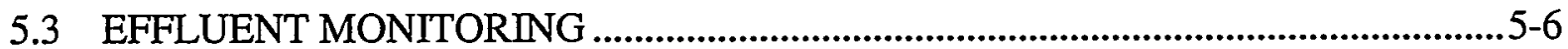


RD99-115

\section{CONTENTS}

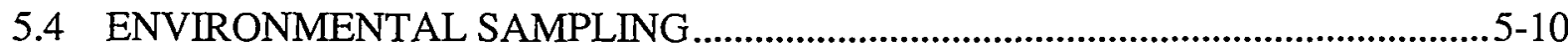

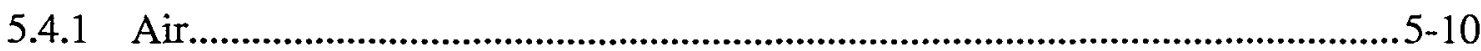

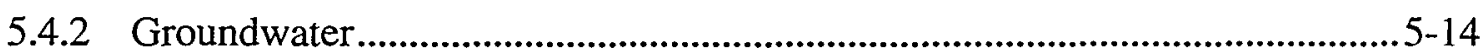

5.4.3 Surface Water and Domestic Water Supply....................................................... 5-16

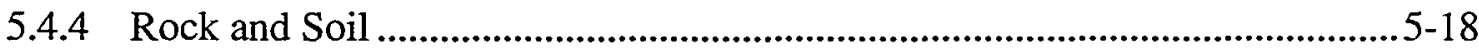

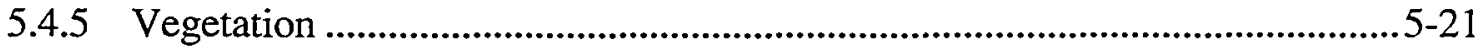

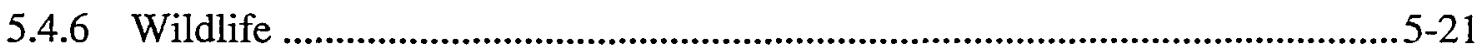

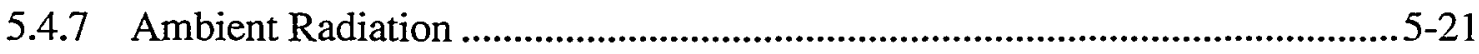

5.5 ESTIMATION OF PUBLIC RADIATION DOSE ............................................. 5-22

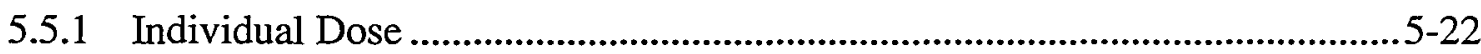

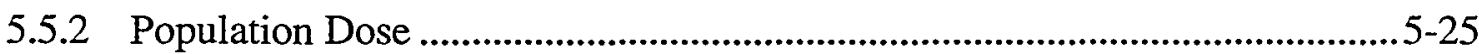

6. ENVIRONMENTAL NON-RADIOLOGICAL MONITORING ..........................................6-1

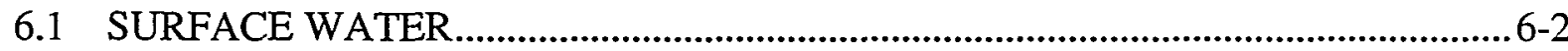

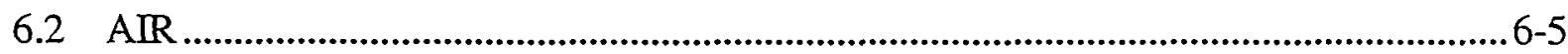

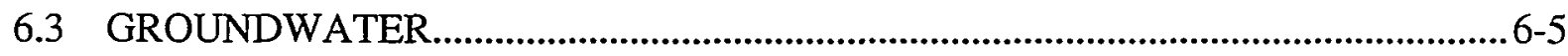

7. ENVIRONMENTAL MONITORING PROGRAM QUALITY CONTROL ...................... 7-1

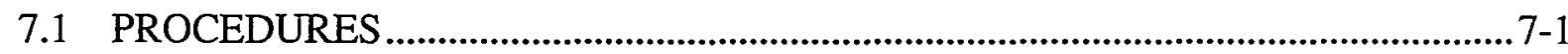

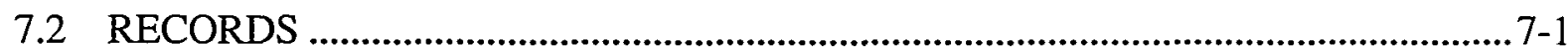

7.3 QUALITY ASSURANCE .......................................................................................

8. REFERENCES

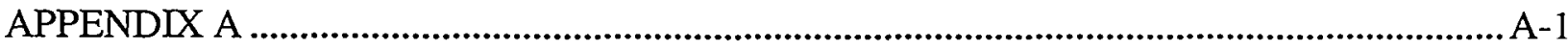

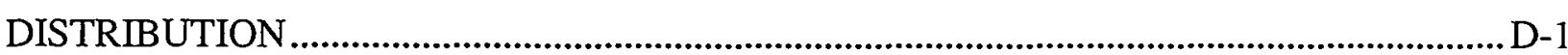




\section{TABLES}

3-1. 1998 Agency Inspections/Visits Related to Environmental Remediation.

3-2. SSFL Current Underground Storage Tanks...................................................................3-14

5-1. Atmospheric Effluents to Uncontrolled Areas...................................................................5-2

5-2. Filtered and Ambient Air Radioactivity Concentrations - 1998 ........................................5-9

5-3. Annual Average Radioactivity Concentrations of Atmospheric Effluents-1998...........5-10

5-4. Sampling Location Description .....................................................................................5-12

5-5. Ambient Air Radioactivity Data-1998 ...........................................................................5-14

5-6. Radioactivity in Groundwater at SSFL - 1998.............................................................5-15

5-7. NPDES Discharge Radioactivity Data For Northwest Slope Monitoring - 1998 ............5-17

5-8. Domestic Water Supplies Radioactivity Data ....................................................................5-17

5-9. $\quad 17^{\text {th }}$ Street Drainage Area Soil Summary...................................................................5-19

5-10. Hot Laboratory Soil Radioactivity Data-1998 ..................................................................5-20

5-11. De Soto and SSFL Ambient Radiation Dosimetry Data-1998 ........................................5-23

5-12. Public Exposure to Radiation and Radioactivity from DOE Operations at SSFL-1998

5-13. Public Exposure to Radiation and Radioactivity from Licensed Operations at De Soto-1998 


\section{FIGURES}

2-1. Santa Susana Field Laboratory Site Arrangement ...............................................2-2

2-2. Map Showing Location of SSFL ..........................................................................2-3

2-3. Area Surrounding SSFL.......................................................................................2-4

2-4. Rocketdyne Propulsion \& Power-Santa Susana Field Laboratory Site, Area IV .......... 2-6

2-5. Map of Santa Susana Field Laboratory Area IV/Radiological Facilities ........................ 2-7

2-6. Rocketdyne Propulsion \& Power-De Soto Site ...........................................................2 2-8

5-1. Map of De Soto Site Monitoring Stations ..............................................................5-10

5-2. Map of Santa Susana Field Laboratory Area IV Sampling Stations .............................5-11

5-3. Tritium Concentration in Water from Well RD-34A ................................................5-16

5-4. Census Tract Boundaries (1990) within 10 miles of SSFL ...........................................5-26

5-5. SSFL Site-Centered Demography to $8 \mathrm{~km}$ (1990), Showing Number of Persons Living in Each Grid

5-6. SSFL Site-Centered Demography to $16 \mathrm{~km}$ (1990), Showing Number of Persons Living in Each Grid.

5-7. SSFL Site-Centered Demography to $80 \mathrm{~km}$ (1990), Showing Number of Persons Living in Each Grid (heavily populated areas are shown by shading)

6-1. Locations of Surface Water Runoff Collectors Along Northwest Boundary of SSFL, Area IV $5-29$

6-2. Location of Wells Used in Groundwater Management Program .......................................6-4

6-3. TCE Occurrences in Groundwater at SSFL, Area IV .................................................. 6-8

7-1. Quality Assessment Program Results for QAP-XLVI and QAP-XLVII ......................... 7-3 


\section{EXECUTIVE SUMMARY}

This Annual Site Environmental Report for 1998 describes the environmental conditions related to work performed for the Department of Energy (DOE) at Area IV of the Rocketdyne Santa Susana Field Laboratory (SSFL) and De Soto facilities. In the past, these operations included development, fabrication, and disassembly of nuclear reactors, reactor fuel, and other radioactive materials, under the Atomics International (AI) Division. Other activities included the operation of large-scale liquid metal facilities for testing of liquid metal fast breeder components at the Energy Technology Engineering Center (ETEC), a government-owned company-operated, test facility within Area IV. AI was merged into Rocketdyne in 1984 and many of the AI functions were transferred to existing Rocketdyne departments. All nuclear work was terminated in 1988, and subsequently, all radiological work has been directed toward decontamination and decommissioning (D\&D) of the previously used nuclear facilities and associated site areas. Large-scale D\&D activities of the sodium test facilities began in 1996.

Results of the radiological monitoring program for the calendar year of 1998 continue to indicate that there are no significant releases of radioactive material from Rocketdyne sites. All potential exposure pathways are sampled and/or monitored, including air, soil, surface water, groundwater, and direct radiation. All radioactive wastes are processed for disposal at DOE disposal sites and other sites approved by DOE and licensed for radioactive waste. Liquid radioactive wastes are not released into the environment and do not constitute an exposure pathway.

Except for low concentrations of tritium, well below Federal and State drinking water standards, in 11 groundwater wells, only naturally occurring radioactivity has been found in groundwater.

Calculated radiation doses to the public, due to airborne releases and direct radiation, are a factor of thousands to millions of times lower than the applicable limits as well as the naturally existing background levels. These theoretically calculated doses are too small to permit direct measurement. Conservative calculations provide upper-limit estimates of possible doses to the public. The radiation dose to a member of the public (maximally exposed individual) because of direct radiation from SSFL is indistinguishable from background. The maximum public dose due to airborne radioactivity released from SSFL facilities is estimated to be $0.0000013 \mathrm{mrem}$. For the De Soto facility, the maximum public dose due to airborne radioactivity is $0 \mathrm{mrem}$ and from direct radiation, 0 mrem. These doses are far below the annual dose from natural indoor airborne activity of about $200 \mathrm{mrem}$, and the total annual dose from all natural sources of about $300 \mathrm{mrem}$.

The non-radiological monitoring program has increased since 1990, with more extensive sampling of the groundwater at the SSFL. Nine wells were installed in Area IV during 1993 and 1994 to characterize the hydrogeology and water quality of known groundwater chemical contamination, horizontally and vertically, and in relation to the potential source areas. Three wells were installed in Area IV in 1994 for extraction and treatment of degraded groundwater bringing the total to 45 . No new wells were drilled between 1995 and 1998 . There were 227 on-site wells that Rocketdyne installed (including the 45 for Area IV) and 16 off-site private wells included in the 1998 groundwater monitoring program for the entire SSFL to characterize the hydrogeology and water quality of known groundwater chemical contamination, horizontally and vertically, and in 
relation to the potential source areas. These water samples were analyzed for chemical and radiological constituents, as appropriate. Two interim groundwater remediation systems operated in Area IV during 1998, one at the Former Sodium Disposal Facility (FSDF) and the other at the Radioactive Material Handling Facility (RMHF). An interim treatment unit operated at Building 4059 for the water pumped to dewater the test vault of the building. The three existing areas of trichloroethylene contamination in the groundwater in the northwest part of Area IV were monitored in 1998.

During 1998, 15 Area IV and 1 De Soto regulatory agency inspections, audits, and visits were conducted. These inspections were carried out by the California Department of Toxic Substances Control (DTSC) the California Department of Health Services Radiologic Health Branch (DHS/RHB), the US Department of Energy (DOE), the Los Angeles Fire Department (LAFD), the Ventura County Air Pollution Control District (VCAPCD), the American Nuclear Insurers (ANI), and the Ventura County Environmental Health Department (VCEHD). There were no Notices of Violations (NOV) as a result of these inspections and audits, however, four unresolved issues resulted from a March 1998 inspection by the California Environmental Protection Agency, DTSC, of the Radioactive Materials Handling Facility.

In summary, this Annual Site Environmental Report provides information showing that no indications of any potential impact on the health and safety of the public are due to the operations conducted at the SSFL and the De Soto site. All measures and calculations of off-site conditions demonstrate compliance with applicable regulations, which provide for protection of human health and the environment. These measurements confirm that the control of hazardous materials and waste at Rocketdyne is extremely effective.

The primary purpose of this report is to present information on environmental and effluent monitoring of DOE-sponsored activities to the regulatory agencies responsible for oversight. Information presented here focuses on Area IV at SSFL, which is the only area at SSFL where DOE operations were performed. In addition, this report attempts to communicate to our workers, neighbors, and customers, factual information regarding the condition of our environment. To assist us in this effort, a reader response survey form has been included in the front of this report. We would appreciate your comments. 


\section{INTRODUCTION}

This annual report discusses environmental monitoring at two manufacturing and test sites operated in the Los Angeles area by The Boeing Company, Rocketdyne Propulsion \& Power. These are identified as Area IV of the SSFL and the De Soto site. These sites have been used for DOE-funded research and development (R\&D), engineering, and testing in a broad range of technical fields primarily in energy research, nuclear reactor technology, and liquid metal components. The De Soto site had R\&D laboratories involved with nuclear research. This work was terminated in 1995, D\&D was completed in 1997, and final surveys conducted in 1998. Area IV at SSFL, because of its large size (290 acres) and the nature of past operations, warrants comprehensive monitoring to ensure protection of the environment. Monitoring was also carried out at the De Soto facility.

\section{SSFL}

The SSFL consists of four administrative areas used for research, development, and test operations as well as undeveloped land. The arrangement of these areas is shown in Figure 2-1. Approximately 90 acres of the 290 acres of Area IV is under the jurisdiction of the Department of Energy.

Since 1956, Area IV had been used for work with nuclear materials, including fabricating nuclear reactor fuels, testing nuclear reactors, and dissembling used fuel elements. This work ended in 1988 and subsequent efforts have been directed toward D\&D of the former nuclear facilities and closure of facilities supporting liquid metal research and testing.

Work in nuclear energy R\&D in what has become Rocketdyne Propulsion \& Power of The Boeing Company began under North American Aviation, Inc. During the evolution of these operations, small test and demonstration reactors and critical assemblies were built and operated, reactor fuel elements were fabricated, and used fuel elements were disassembled and decladded. These projects have been completed and terminated in the course of the past 30 years. Most of this work was performed at Area IV of the SSFL and is described in detail in the Rocketdyne document "Nuclear Operations at Rockwell's Santa Susana Field Laboratory - A Factual Perspective" (Ref. 1). No work with nuclear materials has been conducted at SSFL since 1988, and the only work related to these operations since that time and during 1998 was the ongoing cleanup and decontamination of the remaining inactive nuclear facilities, and the off-site disposal of radioactive waste.

The nuclear operations and the ensuing cleanups have been conducted under State and Federal licenses and under contract to DOE and its predecessors. In April 1990, the Nuclear Regulatory Commission (NRC) Special Nuclear Materials license, SNM-21, was amended to permit only decommissioning operations. Following transfer of ownership of the Hot Laboratory (Hot Lab) from Rockwell International to the DOE, and reflecting the close involvement of DOE in the decommissioning operations, the NRC terminated the SNM-21 license in September 1996 and relinquished responsibility and jurisdiction over the Hot Lab to the DOE (see Section 2.1.1.1). 


\begin{tabular}{|c|l|c|c|}
\hline \multicolumn{3}{|c|}{ Subdivisions } \\
\hline Owner & \multicolumn{1}{|c|}{ Jurisdiction } & Acres & Subtotals \\
\hline Rocketdyne & Rocketdyne-Area IV & 289.9 & \\
& Rocketdyne & 784.8 & \multirow{2}{*}{ R.399.3 } \\
& Rocketdyne (Undeveloped & $1,324.6$ & \\
& land) & 409.5 & 451.2 \\
\hline Government & NASA (former AFP 57) & 41.7 & $2,850.5$ \\
\hline
\end{tabular}

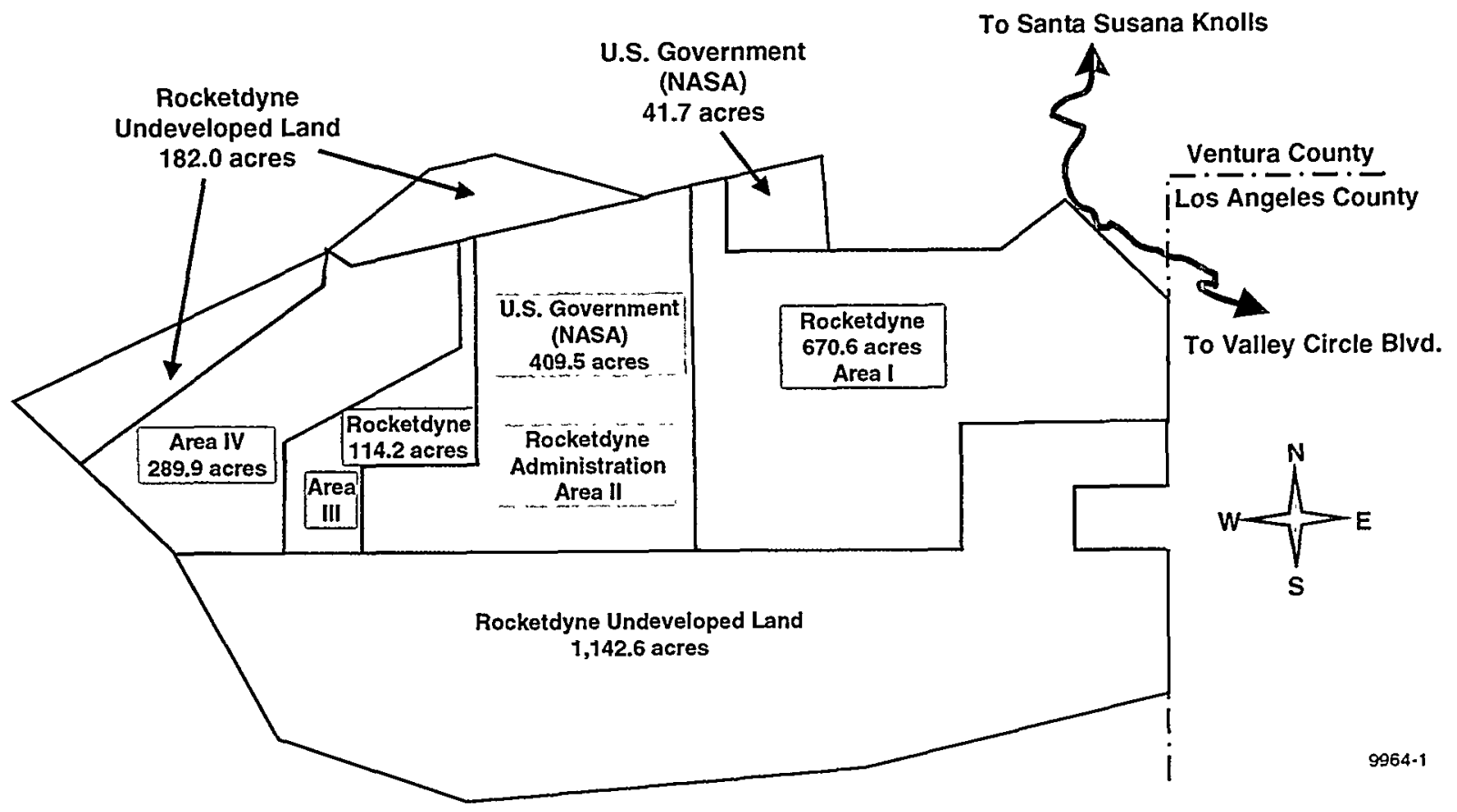

Figure 2-1. Santa Susana Field Laboratory Site Arrangement

The location of the SSFL site in relation to nearby communities is shown in Figures 2-2 and 2-3. Undeveloped land surrounds most of the SSFL site. No significant agricultural land use exists within $30 \mathrm{~km}$ (19 miles) of the SSFL site. While the land immediately surrounding SSFL is undeveloped, suburban residential areas are at greater distances. For example, $2.7 \mathrm{~km}$ (1.7 miles) northwest of Area IV is the closest residential portion of Simi Valley. The community of Santa Susana Knolls lies $4.8 \mathrm{~km}$ (3.0 miles) to the northeast. The Bell Canyon area begins approximately $2.3 \mathrm{~km}$ (1.4 miles) to the southeast, and the Brandeis-Bardin Institute is adjacent to the north. A sand and gravel quarry was operated approximately $2.4 \mathrm{~km}$ (1.5 miles) to the west but is now abandoned. 
RD99-115

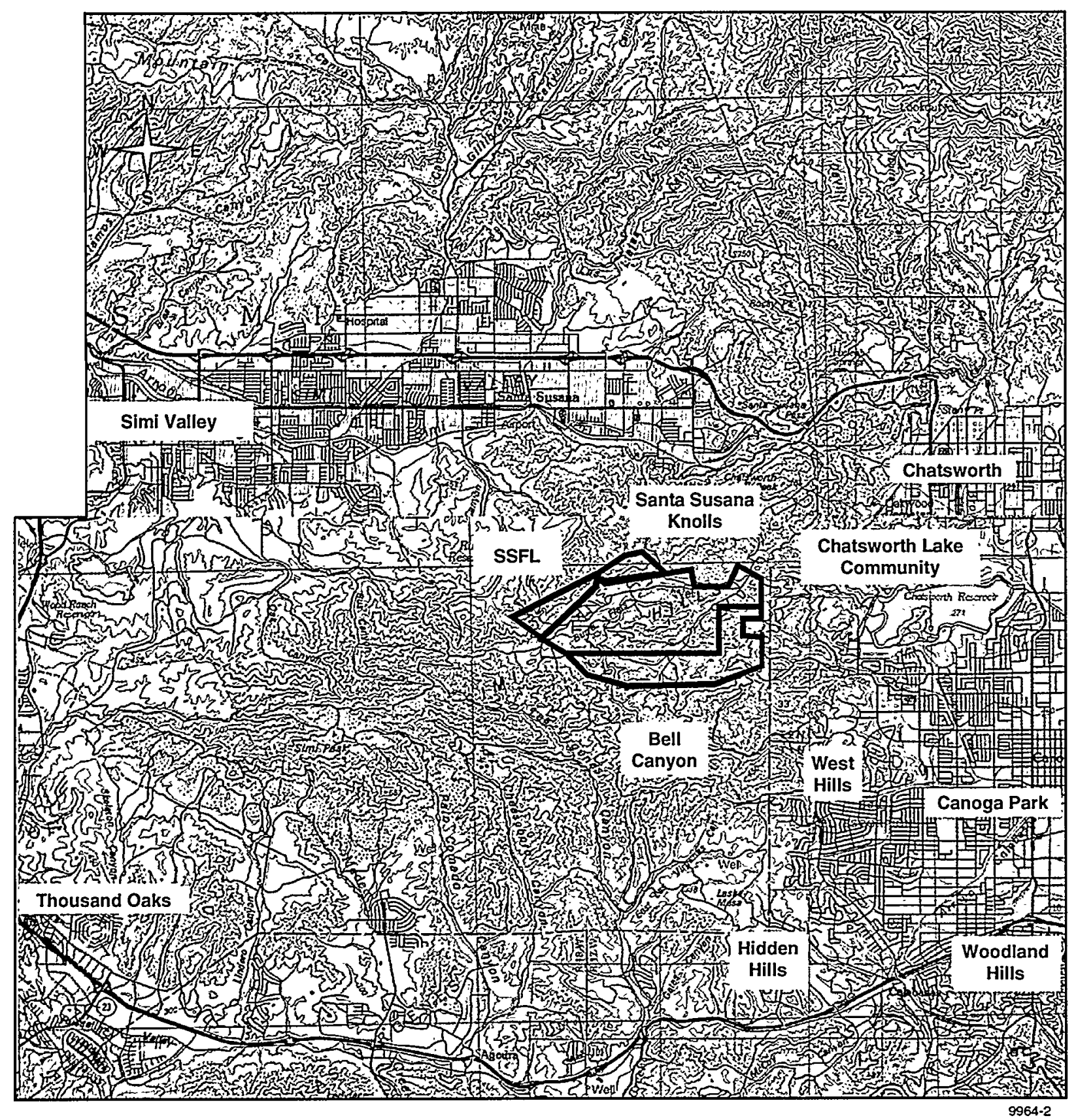

Figure 2-2. Map Showing Location of SSFL 


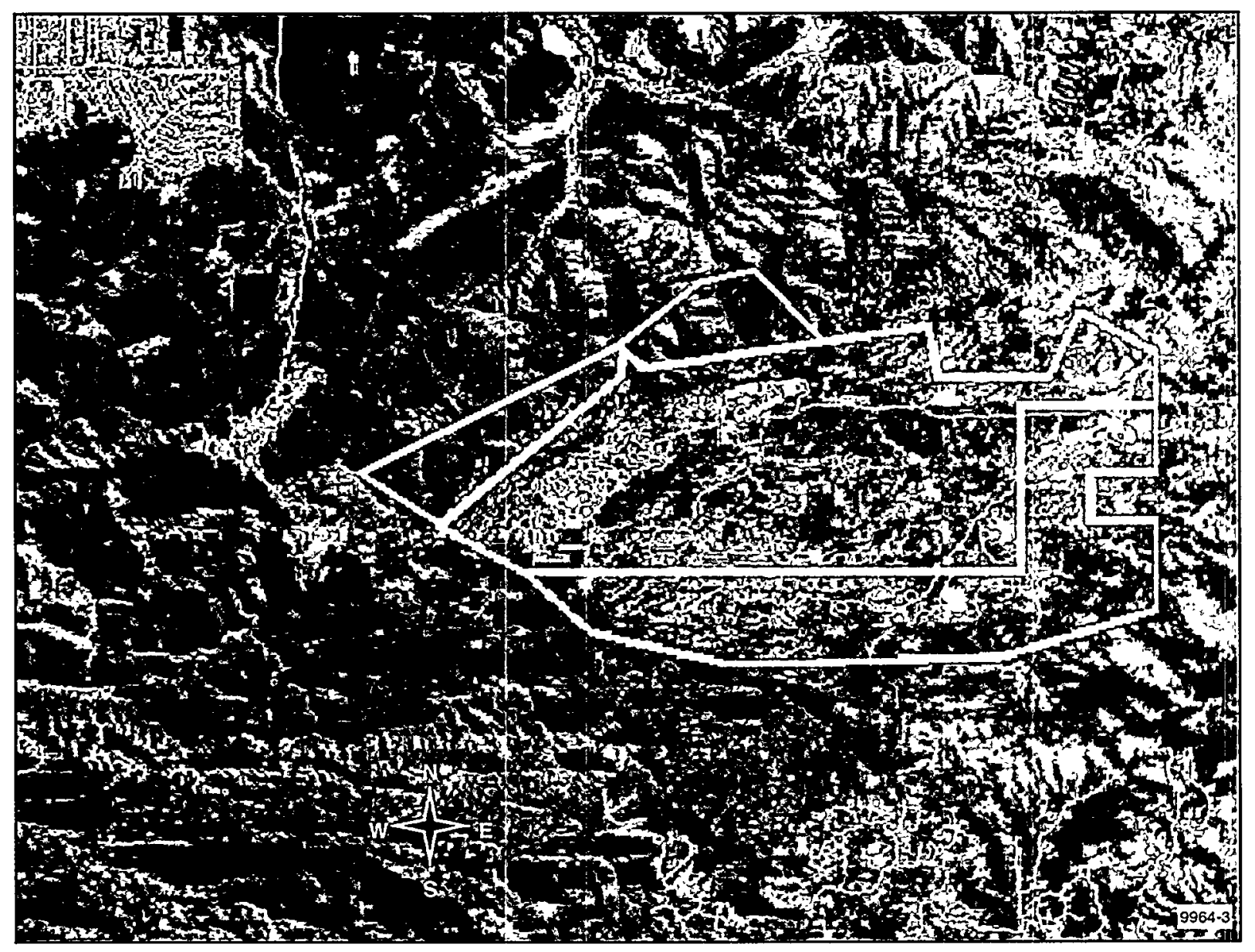

Figure 2-3. Area Surrounding SSFL

The Los Angeles basin is a semiarid region whose climate is controlled primarily by the semi-permanent Pacific high-pressure cell that extends from Hawaii to the Southern California coast. The seasonal changes in the position of this cell greatly influence the weather conditions in this area. During the summer months, the high-pressure cell is displaced to the north. This results in mostly clear skies with little precipitation. During the winter, the cell moves sufficiently southward to allow some Pacific lows with their associated frontal systems to move into the area. This produces light to moderate precipitation with northerly and northwesterly winds.

During the summer, a shallow inversion layer generally exists in the Los Angeles area. The base and top of this inversion layer usually lie below the elevation of the SSFL site. Thus, any atmospheric release from the SSFL site during the summer would likely result in considerable atmospheric dispersion above the inversion layer prior to any diffusion through the inversion layer into the Simi or San Fernando Valleys. In the winter season, surface airflow is dominated by frontal activity moving easterly through the area. Storms passing through the area 
during the winter are generally accompanied by rainfall. Airborne mixing varies depending on the location of the weather front relative to the site. Generally, a light to moderate southwesterly wind precedes these storms, introducing a strong onshore flow of marine air and producing slightly unstable air. Wind speeds increase as the frontal systems approach, enhancing mixing and dispersion. Locally, average wind speeds range from 0 to $4.4 \mathrm{~m} / \mathrm{s}$ ( 0 to $9.8 \mathrm{mph})$, mostly from the north and northwest.

Except for the Pacific Ocean, which is approximately $20 \mathrm{~km}$ (12 miles) south, no recreational body of water of noteworthy size is located in the surrounding area. Four major reservoirs providing domestic water to the greater Los Angeles area are located within $50 \mathrm{~km}$ (30 miles) of SSFL. However, the closest reservoir to SSFL (Bard Reservoir, near the west end of Simi Valley) is more than $10 \mathrm{~km}$ (6 miles) from Area IV.

The SSFL site occupies 2,850 acres located in the Simi Hills of Ventura County, approximately $48 \mathrm{~km}$ (30 miles) northwest of downtown Los Angeles. The SSFL is situated on rugged terrain with elevations at the site varying from 500 to $700 \mathrm{~m}$ (1,650 to 2,250 ft) above sea level (ASL). Rocketdyne and DOE-owned facilities (Figures 2-4 and 2-5) share the Area IV portion of this site.

Within Area IV of the SSFL site is a 90-acre area where DOE contract activities are conducted. Rocketdyne now performs all the DOE work. In 1998, a contract was signed that provides for the closure of all DOE facilities by 2006 .

The major operational nuclear installation within the DOE area is the RMHF. This facility has been used for storage of sealed irradiated nuclear reactor fuel materials and for packaging radioactive wastes resulting from nuclear facility decommissioning operations. No nuclear fuel has been present at the RMHF since May 1989.

The SSFL site also contains facilities in which operations with nuclear materials previously licensed by the NRC and radioactive materials licensed by the State of California were conducted, principally at the Hot Lab. The NRC Special Nuclear Materials license was terminated on September 27, 1996, and jurisdiction for the Hot Lab was transferred to the DOE. During 1998, activities were directed toward the final D\&D stages of the Hot Lab. This work was completed with the removal of the liquid waste hold-up tank structure and the backfilling of the excavation. 


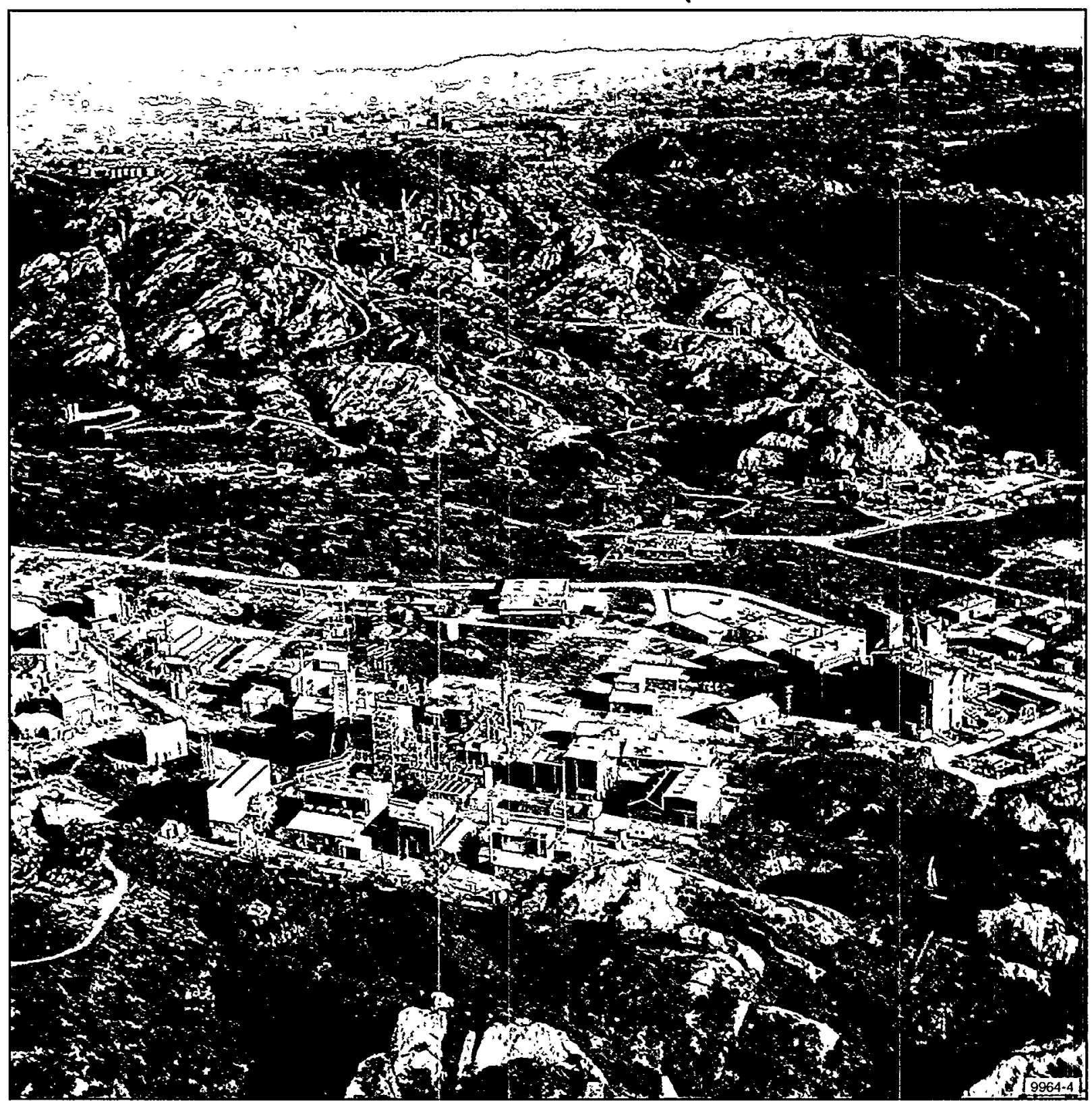

Figure 2-4. Rocketdyne Propulsion \& Power-Santa Susana Field Laboratory Site, Area IV 


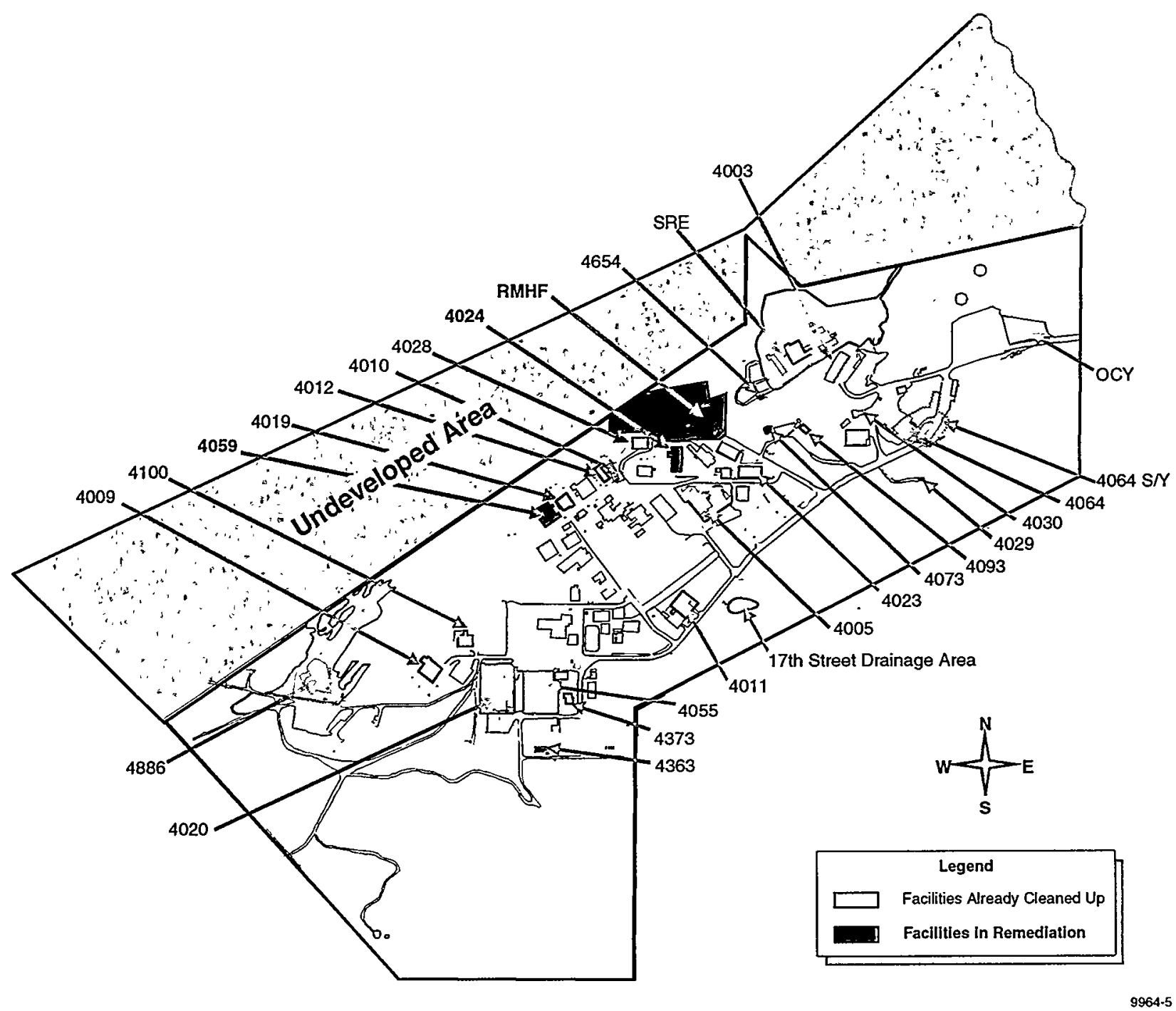

Figure 2-5. Map of Santa Susana Field Laboratory Area IV/Radiological Facilities (as of July 1999)

\section{De Soto}

Up until 1995, research using radioactive materials for DOE and licensed by the State of California was conducted at the De Soto site (Figure 2-6) in the Building 104 Applied Nuclear Technology Laboratories. Irradiation operations in the Gamma Irradiation Facility (GIF) were terminated in 1994 and the radiation sources were shipped off-site. Operations at the Helium Analysis Laboratory were terminated in May 1995, and the equipment was relocated to Battelle-Pacific Northwest National Laboratories (PNNL) in Richland, Washington. This transfer terminated all work (other than D\&D) with radioactive materials at the De Soto site. Decommissioning and final surveys of the Helium Lab and the GIF were completed in 1998. Verification surveys were performed by Oak Ridge Institute for Science and Education (ORISE) and the State DHS/RHB and the facilities are pending final release by the State. 


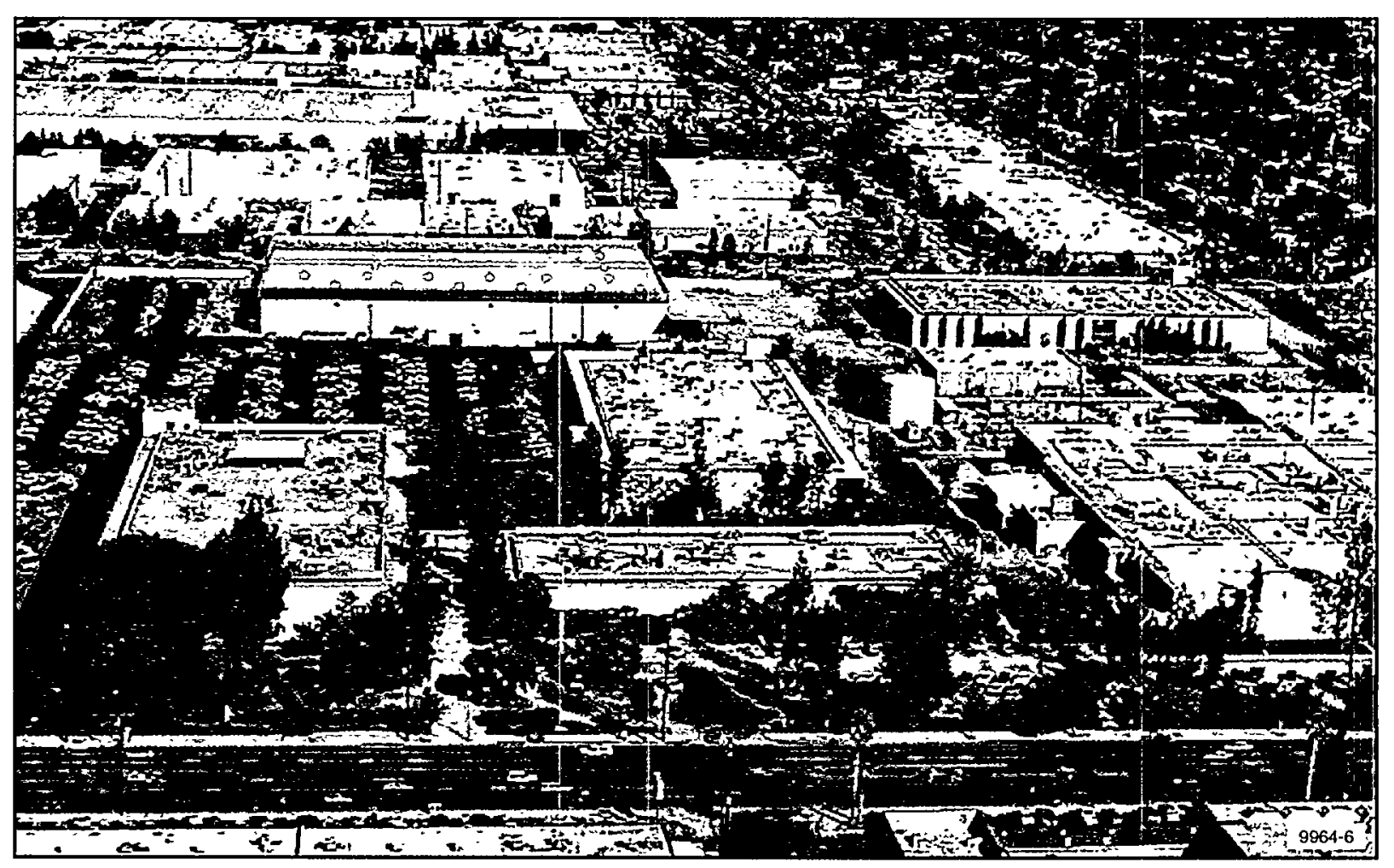

Figure 2-6. Rocketdyne Propulsion \& Power-De Soto Site

Surrounding the De Soto complex is light manufacturing, other commercial establishments, apartment buildings, and single-family homes. The De Soto facility is at an altitude of $267 \mathrm{~m}(875 \mathrm{ft})$ ASL on generally flat terrain.

\subsection{FACILITY DESCRIPTIONS}

These facilities are all undergoing cleanup for radiological and sodium constituents.

\subsubsection{Santa Susana Field Laboratory Site}

\subsubsection{Radiological Facilities}

\section{RMHF}

The Radioactive Materials Handling Facility (RMHF) consists of Buildings 4021, 4022, $4034,4044,4075,4621,4658,4665,4688$, and drainage pond 4614. Operations at RMHF include processing, packaging, and temporary storage of liquid and dry radioactive waste material for shipment off-site to approved DOE disposal facilities. Radioactive waste from decontamination operations contains uranium and plutonium plus $\mathrm{Cs}-137$ and $\mathrm{Sr}-90$ as mixed fission products, and $\mathrm{Co}-60$ and Eu-152 as activation products and tritium. Only sampled atmospheric effluents, filtered for particulates, are released from the buildings. No radioactive liquids are released from the facility. 
Groundwater was pumped throughout 1998 as part of an interim groundwater remediation program. Approximately 793,917 gallons of trichloroethylene (TCE)-contaminated groundwater were pumped and treated at the RMHF Area Interim Extraction and Treatment System (ETS) in 1998.

\section{Building 4059}

Operations at Building 4059 consist of removal of activated steel and concrete as part of the D\&D of this former Systems for Nuclear Auxiliary Power (SNAP) reactor ground test facility. Activation products consist primarily of Fe-55, Eu-152, and Co-60, and minimal amounts of H-3. No radiological work requiring ventilation was performed in the building in 1998, therefore no effluent monitoring was performed. A groundwater treatment system was installed in February 1998 and approximately 559,542 gallons of TCE-contaminated groundwater were processed.

\section{Building 4886, Former Sodium Disposal Facility}

All radioactive contamination was removed from the Former Sodium Disposal Facility (FSDF) in 1994. Final and confirmatory surveys have shown that no radioactivity exceeding allowable limits remains in that area (Refs. 2 and 3). The DHS/RHB released the facility from radiological restrictions in May 1998. A work plan to perform additional chemical remediation is currently being reviewed by DTSC.

An interim ETS was operated at the FSDF in 1998. Approximately 43,750 gallons of TCE-contaminated groundwater were treated.

\section{Building 4064}

Building 4064 was demolished in 1997 and all structure was removed. Contaminated soil in the side yard area of Building 4064 was also removed. The side yard area final and confirmation surveys were performed in 1998 (Ref. 4). Release by the DOE and the State is pending.

\section{Building 4020 (Hot Lab)}

Operations at Building 4020 (Hot Lab) consisted of hot cell examination and decladding of irradiated nuclear fuels and examination of reactor components. Prior radioactive material handled in unencapsulated form in this facility included uranium, plutonium, Cs- 137 and Sr-90 as mixed fission products, and Co-60.

The NRC license for the former Hot Lab was terminated on September 27, 1996. Decommissioning work continued under DOE sponsorship. D\&D activities were completed in 1998 with the removal of the Liquid Waste Holdup Building (4468), two leach pits, and a septic tank. The excavations were backfilled and the area graded. Large concrete blocks resulting from the 1997 basement demolition are surveyed by Rocketdyne and the state DHS/RHB to verify no contamination exists prior to off-site disposal. The facility is now completely demolished. Final radiological and confirmatory surveys of the area will be performed in the summer of 1999 , prior to release. 


\subsubsection{Former Sodium Facilities}

The primary purpose of closure operations for former sodium facilities is the environmental restoration of SSFL areas and facilities that have been impacted by DOE operations.

\section{Buildings 4026/4226/4826 (SCTL)}

Buildings 4026, 4226, and 4826 comprise the Sodium Components Test Loop (SCTL) complex. This facility was used to test small components such as valves and pumps in liquid sodium. In 1996, the sodium in the facility drain tanks (approximately 103,930 pounds) was removed and transferred to a sodium supplier for reuse. In 1997, the two below-grade drain tanks were removed and cleaned using a water-vapor-nitrogen (WVN) process. Approximately 14,300 pounds of sodium was converted to sodium hydroxide during the cleaning process. The sodium hydroxide was recycled and the tanks were cut up and sold as scrap. Also in 1997, the extensive sodium piping system in the SCTL was removed and the pipe cleaned initiated using the WVN process. In 1998, the component and pipe cleaning continued with $90 \%$ of the items completed. Sodium hydroxide generated from the WVN process was recycled and the clean steel was sold as scrap.

\section{Building 4032 (LMDL-1)}

Building 4032 housed the Liquid Metal Development Laboratory 1 (LMDL-1), which carried out applied research in support of liquid metal cooled reactors. In 1996, approximately 15,930 pounds of sodium was removed and transferred to a sodium supplier for reuse from the single below-grade drain tank. During 1997, the drain tank was removed and cleaned using the WVN process. Approximately 1,542 pounds of sodium was converted to sodium hydroxide during the cleaning process. The sodium hydroxide was recycled and the tank cut up and sold as scrap. All the sodium piping has been removed and the facility is being used for storage and component size reduction in support of the WVN cleaning. During 1998, WVN cleaning of all piping and components was completed. Sodium hydroxide generated from the WVN process was recycled and the clean steel was sold as scrap.

\section{Building 4059 (LLTR)}

In 1998, dismantling of the Large Leak Test Rig (LLTR), equipment that had been used for sodium system safety tests in Building 4059 was completed. The dismantling effort had started in 1996 with the removal and shipment of approximately 25,600 pounds of sodium from the facility drain tank. In 1997, the program continued with the cleaning of the drain tank using a WVN process that reacts sodium with water vapor in an inert nitrogen atmosphere to produce sodium hydroxide. Approximately 1,542 pounds of sodium were removed during the cleaning. The remaining major sodium system component, the Reaction Products Tank (RPT), was cleaned in place using the WVN process. This process removed approximately 34,300 pounds of sodium from the RPT in 1997. The sodium hydroxide that was produced as a result of this cleaning process was recycled. All remaining sodium system equipment and components related to the LLTR operations were removed during 1998. 


\subsubsection{De Soto Site}

\section{Building 104-California State-Licensed Activities}

Operations at Building 104 consisted of decommissioning activities of the Helium Analysis Laboratory and Gamma Irradiation Facility (GIF). In late 1997, removal of equipment remaining in the Helium Analysis Laboratory was completed to allow D\&D activities to begin in 1998. During D\&D, facility air was filtered and sampled. No liquid effluents were released. The final radiological survey and DHS/RHB and ORISE confirmatory surveys were completed in 1998 (Refs. 16 and 17). Release of the facility is pending. 
RD99-115

This page intentionally left blank. 


\section{COMPLIANCE SUMMARY}

This section summarizes Rocketdyne's compliance with federal, state, and local environmental regulations. Two main categories are presented: Section 3.1 discusses compliance status, and Section 3.2 discusses current issues and actions.

\subsection{COMPLIANCE STATUS}

\subsubsection{Radiological}

The results of radiological environmental monitoring indicate that there are no significant releases of radioactive material from the SSFL or De Soto sites. Atmospheric transport of radioactive materials and direct exposure during ETEC's environmental remediation and waste management operations are the only credible pathways to the general public.

\subsubsection{Airborne Activity}

Ventilation exhaust effluent from facilities at SSFL and De Soto are minimized by using high efficiency particulate air (HEPA) filters, and are continuously monitored by sampling the exhaust. Radionuclide-specific analyses determine the radioactive composition of these effluents, and maximum off-site doses at the nearest residence from this source are estimated by using the EPA computer program CAP88-PC (Ref. 18). All effective dose equivalents for the maximally exposed individual are far below the EPA National Emissions Standards for Hazardous Air Pollutants (NESHAPs) limit of $10 \mathrm{mrem} / \mathrm{yr}$, and below the action level of $1 \%$ of the limit (0.1 mrem/yr) as specified in 40 CFR 61, Subpart H (DOE facilities) and Subpart I (licensed facilities). The use of COMPLY to demonstrate compliance under Subpart I of the NESHAPs regulations was not required because of the lack of man-made radioactive isotopes.

\subsection{SSFL}

For regulated airborne releases from the RMHF exhaust stack and the Building 4024 exhaust unit, the maximum individual annual exposure was estimated at $1.3 \times 10^{-6} \mathrm{mrem} / \mathrm{yr}$ for DOE operations at SSFL. For the four unregulated diffuse area sources, the dose is estimated to be $2.5 \times 10^{-3} \mathrm{mrem} / \mathrm{yr}$.

\subsection{De Soto}

In 1998, D\&D and final surveys of the Mass Spectroscopy Lab and GIF at De Soto were completed. Only naturally occurring Po-210 was detected in the exhaust effluent. Licensed operations at De Soto site resulted in $0 \mathrm{mrem} / \mathrm{yr}$ for airborne releases because no man-made isotopes were found in the effluent.

\subsubsection{Direct Radiation}

The external radiation exposure estimates at the maximum exposed boundary location and at the nearest residence are based on results from site ambient radiation dosimeters and facility workplace radiation dosimeters. Adjacent to the RMHF, the external exposure from direct radiation at the maximum exposed location was estimated from the 1998 measurements to correspond to an average annual dose of approximately $46 \mathrm{mrem}$ above natural background. 
(This is equivalent to an average exposure rate of $5.3 \mu \mathrm{R} / \mathrm{hr}$.) These values are considerably below the DOE long-term limit of $100 \mathrm{mrem} / \mathrm{yr}$. In February 1998, Rocketdyne's northern property boundary was changed. Because of the new boundary's further distance from the RMHF and the shielding effects of the large rock cliffs between the RMHF and the new boundary, the dose rates there would be indistinguishable from natural background.

De Soto environmental radiation dosimeters are indistinguishable from background (see Table 5-11).

\subsubsection{Groundwater}

All liquid radioactive wastes are processed by either solidification or evaporation prior to disposal at DOE disposal sites. Liquid radioactive wastes are not released into the environment and do not constitute an exposure pathway. Groundwater and surface water in Area IV are sampled and analyzed to assure detection of any non-natural radioactivity.

At SSFL, 243 groundwater monitoring wells included in the monitoring system (including 45 in Area IV) are sampled and analyzed periodically and no indication of non-natural radioactivity has been found, with the exception of low levels of tritium in Well RD-34A (approximately $2,210 \mathrm{pCi} / \mathrm{L}$ in 1998 , see Section 5.5.2), considerably below the Federal and State standards for drinking water of $20,000 \mathrm{pCi} / \mathrm{L}$. Tritium was detected just above the analytical detection limit $(200 \mathrm{pCi} / \mathrm{L})$ in five other wells. Wells with detectable tritium are quite widely separated, near Building 4059, in the canyon north of the RMHF, and at the FSDF (Bldg 4886). Occasional results for gross alpha radioactivity that exceeded the maximum contamination level (MCL) are attributed to naturally occurring uranium (Ref. 24).

Extracted groundwater from the French drain at Building 4059 is periodically sampled and analyzed by gamma spectroscopy. These water samples are tested by gamma spectroscopy for any transfer of gamma-emitting activation products from the underground reactor test vault containment into the surrounding soil. Potential radionuclides include Co-60 and Eu-152, both of which are easily detected, and none have been found to date. This water was sampled three times in 1998, and no non-natural radioactivity was detected.

\subsubsection{Surface Water}

Surface water from two National Pollutant Discharge Elimination System (NPDES) discharge points and five storm water runoff catch basins are also monitored routinely. The Rocketdyne NPDES permit allows the discharge of reclaimed wastewater and storm water runoff from water retention ponds into Bell Creek, a tributary to the Los Angeles River, in addition to the discharge of storm water runoff from the northwest slope (Area IV) locations. Excess reclaimed water, including treated sanitary sewage and runoff from Area IV, is now discharged on a continuous basis through the R-2A outfall location (Outfall 002). Discharge along the northwest slope of Area IV (Outfalls 003 through 007) generally occurs only during and after periods of heavy rainfall. The permit applies the numerical limits for radioactivity in drinking water supplies to drainage through these outfalls. The permit requires radiological measurements of gross alpha, gross beta, tritium, strontium-90, and total combined radium-226 and radium-228. No NPDES samples exceeded drinking water supplier limits for radioactivity, as imposed by the permit. In 1998, there were 78 routine sampling events. 


\subsubsection{Chemical}

\subsubsection{Resource Conservation and Recovery Act}

The Resource Conservation and Recovery Act (RCRA) gives the Environmental Protection Agency (EPA) broad authority to regulate the handling, treatment, storage, and disposal of hazardous wastes. DOE owns and co-operates two RCRA-permitted Treatment, Storage, and Disposal Facilities with ETEC. Permit numbers are listed in Section 3.2.3.

\subsection{RMHF}

In 1998, the RMHF continued to operate as an Interim Status (Part A) permitted facility. This facility is used primarily for the handling and packaging of radioactive waste. Interim status is required for the storage and treatment of the small quantities of mixed waste (waste containing both hazardous and radioactive constituents) resulting from D\&D activities at ETEC. The final disposition of mixed waste is addressed under the DOE and DTSC-approved Site Treatment Plan, which is authorized by the Federal Facilities Compliance Act (FFCA).

In July 1998, the California EPA DTSC requested the completion of the RCRA permitting process for RMHF. Completion of the RCRA permitting involves the creation of an Operations Plan document and following public comment and agency approval, the issuance of a Part B permit by the DTSC. A draft Operations Plan was submitted to DTSC in May 1999.

\subsection{HWMF}

The Hazardous Waste Management Facility (HWMF) includes a storage facility (Bldg 4029) and a treatment facility (Bldg 4133) for reactive metal waste such as sodium. In 1998, the facility entered final closure and will no longer be operated. A closure plan was submitted to the DTSC in January 1999.

\subsection{Sodium Removal}

Removal of metallic sodium from the closed facilities continued in 1998. Removal of sodium is accomplished by bulk transfer and by conversion of metallic sodium into usable sodium hydroxide. The bulk sodium and piping residuals are managed as an "excluded recyclable material" in accordance with applicable regulations. In 1998, a total of 212,500 pounds of sodium were removed from Area IV. Two tanks were drained of bulk sodium and a WVN cleaning technique was used to remove the residuals. Other tanks that were drained in 1998 will be cleaned in 1999.

\subsection{RCRA Facility Investigation (RFI)}

Under the Hazardous and Solid Waste Amendments of 1984, RCRA facilities can be brought into the corrective action process when an agency is considering any RCRA permit action for the facility. The SSFL was initially made subject to the corrective action process in 1989 by EPA, Region IX. The EPA has performed the Preliminary Assessment Report and the Visual Site Inspection portions of the RCRA Facility Assessment (RFA) process. 
The State of California DTSC has RCRA authorization and has become the lead agency in implementing the corrective action process for the SSFL. ETEC has performed soil sampling at various Solid Waste Management Units (SWMUs) and Areas of Concern (AOCs) that were identified in the RFI Work Plan.

The current conditions report and a draft of the RFI Work Plan for the Area IV SWMUs were submitted to the DTSC in October 1993. In November 1996, DTSC approved a revised work plan addendum. Fieldwork in areas of unrestricted use began in November 1996 and is scheduled for completion in 1999.

Fieldwork in 1998 included collecting soil vapor and soil matrix samples from both the Old Conservation Yard and the Building 4056 landfill. To date, approximately 12 soil vapor and 77 soil matrix samples have been collected and analyzed. The chemical analysis was performed by State certified laboratories and validated by Ogden Environment, the RFI contractor. In addition to fieldwork, a Standardized Risk Assessment Methodology (SRAM) was developed to facilitate risk assessments of the DOE SWMUs. The SRAM was submitted to the California DTSC for review and approval.

\subsubsection{Federal Facilities Compliance Act}

ETEC is managing its modest inventory (approximately $18 \mathrm{~m}^{3}$ ) of mixed wastes in accordance with the FFCA-mandated Site Treatment Plan (STP) approved in October 1995. During CY98, ETEC achieved an $85 \%$ reduction in its mixed low level radioactive waste (MLLW) inventories by shipping approximately 50 cubic meters of waste to an off-site treatment, storage, and disposal facility (TSDF) for treatment and disposal. All mixed wastes that require on-site storage beyond the regulatory (i.e., per RCRA) allowed time limits are managed within the framework of the STP. Characterization, treatment, and disposal plans for each of several different waste streams are defined in the STP with enforceable milestones. These include characterization, reporting, study of treatment options, shipping schedules, and actual removal. ETEC has met all STP milestones to date. Regular updates to reflect changes in inventory or status of mixed wastes and certifications of milestone completion are submitted to DTSC in accordance with the STP.

\subsubsection{National Environmental Policy Act}

The National Environmental Policy Act (NEPA) establishes a national policy to ensure that consideration is given to environmental factors in federal planning and decision-making. For those projects or actions expected to either affect the quality of the human environment or create controversy on environmental grounds, DOE requires that appropriate NEPA actions (Categorical Exclusion [CX], Environmental Assessment [EA], Finding of No Significant Impact [FONSI], or Notice of Intent [NOI], draft Environmental Impact Statement [EIS], final EIS, Record of Decision [ROD]) have been incorporated into project planning documents. DOE has implemented NEPA as defined in Federal Register Volume 57, Number 80, pages 15122 through 15199 and in accordance with the DOE O 451.1A.

Environmental impacts of each new project are assessed. Based on the assessments, DOE is requested to issue determinations of compliance to the NEPA. No new request for NEPA determination was submitted in the calendar year 1998. There were no draft or final 
environmental impact statements or reports, site assessments, or remedial action reports produced during 1998. Additionally, no actions were taken by local authorities and no NOVs relative to the Comprehensive Environmental Response, Compensation, and Liability Act (CERCLA)/Superfund Amendments and Reauthorization Act (SARA) activities for the DOE area.

\subsubsection{Clean Air Act}

The Clean Air Act (CAA) resulted in federal regulations that set air quality standards and required state implementation plans, National Emissions Standards for Hazardous Air Pollutants (NESHAPs), New Source Performance Standards (NSPSs), and monitoring programs in an effort to achieve air quality levels beneficial to the public health and welfare. The SSFL is regulated by the Ventura County Air Pollution Control District (VCAPCD) and must comply with VCAPCD Rules and Regulations. The EPA can enforce VCAPCD rules and regulates pollutants such as Ozone Depleting Substances (ODS) under 40 CFR 82. The De Soto facility is under the jurisdiction of the South Coast Air Quality Management District (SCAQMD). VCAPCD and SCAQMD rules and regulations incorporate, by reference, NESHAPs regulations as codified under the CAA.

\subsubsection{Clean Water Act}

The Clean Water Act (CWA) is the primary authority for water pollution control programs, including the National Pollutant Discharge Elimination System (NPDES) permit program. The NPDES program regulates point source discharges of surface water to drainage channels (i.e., to locations other than sewage systems), and the discharge of storm water runoff associated with industrial activities. Basin Plan water quality objectives are applied as effluent standards for offsite discharge of storm and industrial wastewater via the SSFL water reclamation system.

Surface water discharges from SSFL are regulated under the California Water Code (Division 7) as administered by the California Regional Water Quality Control Board (CRWQCB). The existing NPDES Permit (CA0001309) for SSFL, which was revised and became effective June 29, 1998, is expected to remain in force through May 10, 2003. The revised NPDES Permit incorporated the General Permit (No. CAS000001) for storm water, which includes the requirement for a site-wide Storm Water Pollution Prevention Plan (SWPPP). The SWPPP is revised as needed and includes by reference many existing pollution prevention plans, policies, and procedures implemented at the SSFL site. Several key elements of the plan, including maps, are continually updated. Another key element is the Rocketdyne procedure "SSFL Storm Water' Pollution Prevention Requirements." The Spill Prevention Control and Countermeasure (SPCC) plan serves to identify specific procedures for handling oil and hazardous substances to prevent uncontrolled discharge into or upon the navigable waters of the State of California or the United States. The U.S. EPA requires the preparation of an SPCC plan by those facilities that, because of their location, could reasonably be expected to discharge oil in harmful quantities into or upon navigable waters. A revised SPCC plan was submitted as a part of the revised Spill Prevention and Response Plan to the local Administering Agency on February 18, 1999. 
Additionally, an updated hazardous materials inventory was submitted to the VCEHD as an update of the business plan on February 18, 1999. The hazardous materials disclosure fee was also submitted.

Water from Rocketdyne operations is collected into and discharged from the R2A Pond. Sewage from Area IV (including DOE facilities) is treated at the Area III Sewage Treatment Plant (STP), which discharges to the R2A Pond. Most surface runoff from Area IV also drains to R2A Pond. The northwest slope of Area IV drains through five small catch basins. During periods of rainfall, and when there is adequate runoff for sampling, grab samples of surface water runoff are collected at the outfalls. Samples are collected no more than twice a month (biweekly) per outfall during the rainy season. In the dry season, if discharges occur on a continual basis, samples are collected monthly. The sampling performed at the five northwest slope locations includes quarterly monitoring for a list of analytes referred to as "priority pollutants." There was no NOVs of the NPDES permit in 1998.

With few exceptions, the seven outfalls were in full compliance for 1998. Outfalls 002, 004, and 005 each had one incident of noncompliance in 1998. As typical for August, there was a decrease in the overall volume of water being discharged from the facility with the flow stream diminishing to a mere trickle at the sampling location. Consequently, sediment from the unlined drainage channel was unintentionally collected along with sample water. This unfortunately resulted in exceeding the 30-day average limit of $15 \mathrm{mg} / \mathrm{L}$ for total suspended solids at Outfall 002. At Outfall 004, results of the January 9, 1998 chronic toxicity analysis did not meet the permit requirement of 1 toxic units chronic (TUc). Results from the additional sampling have demonstrated compliance with the established limit and provided no evidence of any problem at this sampling location. It is believed that this was an anomaly possibly attributable to laboratory error considering results could not be duplicated. The Outfall 005 analytical results for the November 30, 1998 sampling event reported total mercury at $0.2 \mathrm{ug} / \mathrm{L}$. Results from the dissolved mercury analysis were at non-detectable levels. Standard methods for total metals analysis require the digestion of all matter collected in the sample, including sediment. Mercury has been detected in soil samples collected at the Former Sodium Disposal Facility-an area currently under remediation through the oversight of the Department of Toxic Substances Control (DTSC). Sediment traps (weirs) have been installed in the drainage channels as an interim measure prior to the completion of remedial activities. Outfalls 003, 006, and 007 had no incidents exceeding permit limits 1998. All outfalls are on Rocketdyne property.

At the Area III Sewage Treatment Plant (STP III), the discharge standard of $85 \%$ BOD removal was not met from February through June 1998. In addition, the STP III exceeded the 2 nephelometric turbidity units (NTU) daily average turbidity limit from August through December 1998. A Rocketdyne team has been formed to address difficulties in achieving consistent compliance with discharge standards at the STPs. During 1998, operational and procedural changes were implemented at both STPs to improve plant performance and reliability. Over $\$ 80,000$ has been spent on new equipment and an extensive capital improvement plan has been initiated. STP performance is continuously tracked and reported to upper management on a monthly basis. These actions have resulted in complete compliance with discharge standards in 1999 thus far. 
Characterization of the groundwater at the site continues. TCE continued to be detected in three areas of Area IV during 1998 at concentrations ranging from 2.6 to $9.8 \mu \mathrm{g} / \mathrm{L}$ in groundwater inside the northern boundary of SSFL. TCE and other volatile organic compounds (VOCs) were also detected in three on-site areas within the northwestern property boundary.

\subsubsection{Former Sodium Disposal Facility Closure Order}

Chemical analyses of soil have indicated the continued presence of residual chemical contaminants in the upper basin, western area, and drainage channels. The contaminants of concern were polychlorinated biphenyls (PCBs), dioxins, and mercury. As a result, interim measures have been implemented after consultation with the DTSC, including establishment of sediment weirs downslope of the facility. A health-based risk assessment has been performed and is under DTSC review. An interim measure consisting of excavation, backfilling, and revegetation was proposed to DTSC for completion in 1999. Results from radiological analyses have shown no activity above allowable limits and the DHS/RHB released the facility for unrestricted use in 1998.

\subsubsection{Public Participation}

During 1998, Rocketdyne has continued and expanded its commitment to community involvement by hosting five homeowners association and community meetings and three bus tours at the Santa Susana Field Laboratory (SSFL). These activities provided a two-way exchange of information for more than 700 community members. Rocketdyne staff members and technical experts were on hand with display boards and exhibits to enhance understanding of the technological and scientific mission at SSFL as well as all environmental programs at the facility. Surveys indicated a very positive response to these meetings and the sharing of information. Rocketdyne also supported four regulatory agency-sponsored meetings and provided information to local elected officials.

In addition to these efforts, at the request of the Bell Canyon Homeowners Association, Rocketdyne conducted environmental sampling to determine if its operations had an impact on the Bell Canyon area. At an association meeting, Rocketdyne environmental professionals reported that no contamination had been found that posed a health threat to Bell Canyon residents.

In the fall of 1998, Rocketdyne initiated the Think Earth environmental educational enrichment program at a local elementary school. Lessons focus on helping students become more aware about their environment and learning to reduce, reuse, or recycle.

In support of Rocketdyne's Educational Outreach program, the SSFL Council hosts several teacher and student tours each year at the field lab. The tours provide an opportunity for the teachers and students to see the historical site and talk to scientists and engineers involved in field lab programs.

Rocketdyne continues to supply three local repositories with information on environmental remediation projects at the site. In addition, Rocketdyne catalogues and inventories the documents at two of these repositories. 
Rocketdyne maintains a community mailing list of about 800 people. Rocketdyne distributed information to these community members as a part of our ongoing community outreach and on behalf of the regulatory agencies.

\subsubsection{Agency Inspections/Audits}

A list of inspections, audits, and site visits by the various agencies overseeing the SSFL and De Soto sites is given in Table 3-1. No NOVs were issued as a result of these inspections and audits, however, four unresolved issues resulted from a March 1998 inspection by the California Environmental Protection Agency, Department of Toxic Substances Control, of the Radioactive Materials Handling Facility.

Table 3-1. 1998 Agency Inspections/Visits Related to Environmental Remediation

\begin{tabular}{|c|c|c|c|}
\hline Date (1998) & Agency & Subject Area & Results \\
\hline January & $\begin{array}{l}\text { DHS Radiologic Health } \\
\text { Branch }\end{array}$ & $\begin{array}{l}\text { Conduct } 4^{\text {th }} \text { Quarter } \\
\text { thermoluminescent dosimeter (TLD) } \\
\text { Exchange }\end{array}$ & Compliant \\
\hline February & American Nuclear Insurers & $\begin{array}{l}\text { Annual Inspection of Radiation Safety } \\
\text { Program }\end{array}$ & Compliant \\
\hline March & $\begin{array}{l}\text { DHS Radiologic Health } \\
\text { Branch }\end{array}$ & $\begin{array}{l}\text { Verification of } B / 020 \text { concrete blocks, } \\
\text { re-survey } B / 030\end{array}$ & Compliant \\
\hline March & DTSC & $\begin{array}{l}\text { ETEC mixed waste generator point, } \\
\text { RCRA inspection }\end{array}$ & Pending \\
\hline April & $\begin{array}{l}\text { DOE Oakland Radiation } \\
\text { Safety }\end{array}$ & $\begin{array}{l}\text { Appraisal of Internal Dosimetry } \\
\text { Program }\end{array}$ & Compliant \\
\hline April & $\begin{array}{l}\text { DTSC and L. A. City Fire } \\
\text { Dept }\end{array}$ & $\begin{array}{l}\text { Exemption for a Phase I site } \\
\text { assessment requirement }\end{array}$ & Compliant \\
\hline April & $\begin{array}{l}\text { DHS Radiologic Health } \\
\text { Branch }\end{array}$ & Conduct $1^{\text {st }}$ Quarter TLD Exchange & Compliant \\
\hline May & VCAPCD & $\begin{array}{l}\text { Annual inspection of Permit to Operate } \\
\text { (Permit 0271) }\end{array}$ & Compliant \\
\hline June & Ventura County Fire Dept & $\begin{array}{l}\text { Inspect brush clearing efforts } \\
\text { throughout SSFL }\end{array}$ & Compliant \\
\hline July & $\begin{array}{l}\text { DHS Radiologic Health } \\
\text { Branch }\end{array}$ & Conduct $2^{\text {nd }}$ Quarter TLD Exchange & Compliant \\
\hline August & $\begin{array}{l}\text { DHS Radiologic Health } \\
\text { Branch }\end{array}$ & $\begin{array}{l}\text { Inspection and final verification of } \\
\mathrm{B} / 4009\end{array}$ & Compliant \\
\hline August & $\begin{array}{l}\text { DHS Radiologic Health } \\
\text { Branch }\end{array}$ & Verification of $B / 4020$ concrete blocks & Compliant \\
\hline October & $\begin{array}{l}\text { DHS Radiologic Health } \\
\text { Branch }\end{array}$ & $3^{\text {rd }}$ Quarter TLD exchange & Compliant \\
\hline October & $\begin{array}{l}\text { DHS Radiologic Health } \\
\text { Branch }\end{array}$ & $\begin{array}{l}\text { Verification surveys of } B / 4020, B / 4019 \text {, } \\
B / 4064 \text {, and } B / 104\end{array}$ & Compliant \\
\hline December & $\begin{array}{l}\text { Ventura County } \\
\text { Environmental Health }\end{array}$ & $\begin{array}{l}\text { Permanent closure (removal) of } \\
\text { underground storage tank UT-71 }\end{array}$ & Compliant \\
\hline
\end{tabular}




\subsection{CURRENT ISSUES AND ACTIONS}

\subsubsection{Progress in Decommissioning Operations}

\subsubsection{1997 Summary Accomplishments}

During 1997, the Department of Energy (DOE) released five DOE-owned buildings at the Rocketdyne Santa Susana Field Laboratory (SSFL) for unrestricted use. This followed extensive radiological surveys by Rocketdyne, ORISE, and the DHS/RHB to verify that the buildings posed no further radiological hazard.

These properties were the SNAP Critical Facility (Bldg 4012) (Refs. 5, 6 and 7), the Sodium Corrosion Test Loop (Bldg 4023) (Refs. 12, 13, and 14), the SNAP Test Irradiation Reactor (Bldg 4028), the Radiation Measurement Facility (Bldg 4029), and the van de Graaff Accelerator Facility (Bldg 4030) (Refs. 10 and 11). Notices of Certification of Release of these buildings have been published in the Federal Register.

\subsubsection{1998 Summary Accomplishments}

In 1998, the State Department of Health Services Radiologic Health Branch (DHS/RHB) released three Rocketdyne-owned,' State Licensed facilities and "concurred" with DOE's release of one DOE-owned facility. This followed extensive radiological surveys by both Rocketdyne and the DHS/RHB to verify that the buildings posed no further radiological hazard.

The released facilities were the Sodium Disposal Facility (Bldg 4886) (Refs. 2 and 3), the Sodium Corrosion Loop Test Lab (Bldg 4023), the Radiation Instrument Calibration Lab (Bldg 4011), and the SNAP Component Test Facility (Bldg 4363) (Refs. 8 and 9).

During 1998, Rocketdyne also completed cleanup and final surveys of two facilities at De Soto and two facilities at the SSFL. These were the Gamma Irradiation Facility and the Helium Laboratory in Building 104 (Refs. 16 and 17), and the SNAP Flight System Critical Facility (Bldg 4019) (Ref. 11) and the Fuel Storage Facility Side Yard (Bldg 4064) at the SSFL. In addition cleanup was completed at the Hot Lab (Bldg 4020) (Ref. 15). See Section 3.2.1.4 for further details on the 1998 cleanup accomplishments.

\subsubsection{1999 Summary Accomplishments}

In 1999, the State Department of Health Services Radiologic Health Branch (DHS/RHB) released two buildings at the Rocketdyne SSFL for unrestricted use. This followed extensive radiological surveys by both Rocketdyne and the DHS/RHB to verify that the buildings posed no further radiological hazard.

The released facilities were the van de Graaff Accelerator Facility (Bldg 4030) (Refs. 10 and 11) and the Organic Moderated Reactor/Sodium Graphite Reactor (Bldg 4009). The State DHS/RHB also removed the Hot Lab (Bldg 4020) from Rocketdyne's Radioactive Materials License. 
During 1999, we anticipate obtaining approval for release, for unrestricted use, the GIF and Helium Lab at De Soto in addition to SSFL Building 4019, the 4064 Side Yard, and the Interim Storage Facility (BIdg 4654).

\subsubsection{1998 Cleanup Status}

\subsection{Building 4020 (Hot Lab)}

The Hot Lab foundations and basement were excavated in 1997. Rocketdyne, ORISE, and the California DHS sampled the remaining soil in the excavated hole and verified that no contamination remained (Ref. 15). The hole was then backfilled prior to the 1997/98 rainy season.

In 1998, an ancillary building called the Radioactive Liquid Waste Storage Building (Bldg 4468) was demolished and excavated in addition to excavation of two septic columns and a leach field. Though inside Building 4468 was contaminated, the septic tanks and leach field were not and neither was any soil surrounding these items. Once again, Rocketdyne, ORISE, and the California DHS soil sampled the excavation and verified that no contamination remained. The hole was then backfilled prior to the 1998/99 rainy season.

The remaining land will be gridded, surveyed, and sampled as part of the final status survey following new Multi-Agency Radiation Survey and Site Investigation Manual (MARSSIM) protocols in the summer of 1999. Following verification surveys by ORISE and the California DHS, the land will be released for unrestricted use.

Release of "Clean Material." As part of an agreement between Rocketdyne and the California DHS, Rocketdyne agreed to sequester building structural debris that it had surveyed clean, for a second verification survey by the DHS prior to disposing of the clean building debris off-site. In this way, all clean debris from the Hot Lab, disposed off-site, has been released for unrestricted use by the California DHS.

Ownership and Licensing of the Hot Lab. During 1996, the ownership of the Hot Lab was transferred from Rocketdyne to the DOE. Subsequently, in September 1996, the Nuclear Regulatory Commission License SNM-21, was terminated. Finally, in January 1999, the Hot Lab was removed from the California Radioactive Material License 0015-19.

\subsection{Building 4064 Sideyard}

Two locations, one in the original side yard and one located across the other side of " $G$ " Street were identified as exceeding release limits. These areas were excavated in 1997 including the removal of an abandoned septic tank and leach field that had serviced Building 4064. Scoping surveys and soil samples conducted during and after excavation indicated that the area beneath the previous building foundations and surrounding yard areas were non-contaminated.

In May 1998, subsurface core sampling down to bedrock was performed under the original building, in the side yard, under the main access road, "G" street, and east of " $G$ " street. All sample results proved to be within the range of background. 
In September 1998, the Final Status Survey was conducted in the entire 2 acres of area 4064, including drainage pathways, former parking lot areas, surrounding areas, and the side yard area. A surface exposure survey of all 2 acres was performed, and 131 soil samples and 553 one-meter gridded exposure measurements were taken. All measurements demonstrated that the facility met cleanup standards for release for unrestricted use. The Final Status Survey Report was issued in April 1999 (Ref. 4).

In September 1998, the ORISE performed a verification survey. In October 1998, the California DHS performed a verification survey. The final and verification survey reports will be published prior to final release for unrestricted use.

\subsection{Building 4019}

The SNAP Flight System Critical Facility was also called the Acceptance Test Facility. This facility was built to do criticality acceptance tests of SNAP reactors before they were to be delivered to the Atomic Energy Commission (AEC) for launch as space power systems. The criticality tests of the S10FS3 reactor were performed in this building in 1963. Criticality tests of other flight-qualified SNAP 10 reactors were also done in this building including SNAP 10A, which was launched in April 1965. All nuclear materials were removed from Building 4019 following removal of the last SNAP reactor in 1965.

In 1998, the entire building, including high-bay test vault, associated rooms, and offices underwent a final status survey and were demonstrated to meet cleanup standards. Also in September/October 1998, ORISE and the State DHS performed verification surveys of Building 4019. Based on the results of these three surveys, it is anticipated that the building will be released for unrestricted use in 1999.

\subsubsection{4 $17^{\text {th }}$ Street Drainage Area}

A natural rainwater drainage channel exists south of the intersection of $G$ Street and 17 th Street. In 1962, this channel was bermed to provide a hold up pond approximately $30 \mathrm{ft}$ by $30 \mathrm{ft}$. The pond appears to have been functional for many years and went through many periods of evaporative drying during the summers and refilling during the rainy seasons. During subsequent years, the area became overgrown with shrubs and trees, and the pond filled with silt. During rainy seasons the low-lying area was marshy but would dry up each summer.

During the Area IV Radiological Survey in 1995, this area was found to be both completely overgrown and marshy, and was judged inaccessible. The drainage channels to the north and south of the pond area were soil sampled and no contamination was found. Subsequently, in 1997, during inspection of historical aerial photos, the existence and location of the old pond was identified and investigated. Several soil samples were taken in the area (which was now dry) and two samples showed cesium-137 at 13 to $15 \mathrm{pCi} / \mathrm{g}$. A radiation survey was done in the area, and localized areas exceeding background by $\sim 100 \%$ were identified.

In 1998, the entire area was cleared of weeds and shrubs. The original bermed pond area was gridded and surveyed including all the upper drainage into the pond and the lower drainage away from the pond. One-meter high exposure measurements did not exceed $18.4 \mu \mathrm{R} / \mathrm{hr}$ in a background of $15 \mu \mathrm{R} / \mathrm{hr}$. Localized areas of elevated radiation at ground level were observed up 
to a maximum of twice background. All locations that exceeded ground level exposure rates of more than $5 \mu \mathrm{R} / \mathrm{hr}$ above background were marked.

These areas of elevated radiation were soil sampled at varying depths. Most locations indicated only naturally occurring radionuclides. However, several areas immediately to the north and immediately to the south of the berm showed levels of radionuclides above local background. Cesium-137 was again found up to $2 \mathrm{pCi} / \mathrm{g}$ (but less than the cleanup standard of $9.2 \mathrm{pCi} / \mathrm{g}$ ), uranium isotopes were found up to $4 \mathrm{pCi} / \mathrm{g}$ (but less than the cleanup standard of $30 \mathrm{pCi} / \mathrm{g}$ ), and thorium-228 was found up to $6 \mathrm{pCi} / \mathrm{g}$ (at around the cleanup standard). All uranium results showed ratios of uranium isotopes, which were consistent with naturally occurring uranium and not processed or enriched uranium, which was typical of nuclear fuel used at SSFL. Although thorium-228 was found at $6 \mathrm{pCi} / \mathrm{g}$, its parent isotope, thorium-232 was found at typical background levels (e.g., $1 \mathrm{pCi} / \mathrm{g}$ ), thus the origin or cause of elevated thorium228 is uncertain since this specific thorium isotope was not processed or used at SSFL.

Although the majority of samples did not exceed cleanup standards and did not pose a risk to anyone, they were nevertheless excavated. Soil sampling performed after excavation showed that excavation had been effective in reducing even these low levels further below cleanup standards.

A final survey by Rocketdyne was completed in the spring of 1999 . Verification surveys by the ORISE and the California DHS are planned for September 1999. These surveys will demonstrate that no residual contamination remains that could result in any exposure or risk to current or future users.

\subsection{Building 4059}

D\&D of the below-grade part of the facility was initiated in 1987 . Between 1987 and 1989 , the vacuum system suction pipe and its sand shielding were removed. The next phase involved removing the vacuum chamber and the concrete test cell walls (which contained activation products). This was suspended in 1995 following removal of the majority of the activated concrete.

Removal of other non-radiological systems and equipment, including Tank UT-24, occurred in 1996 though 1998. The final phase of radiological remediation was initiated in 1998. The above grade portion of Building 4059 and the underground non-activated portions of the basement has been cleaned, final surveyed, and will be subjected to verification surveys by the ORISE and the California DHS. This part of the building will then be released for unrestricted use, and demolished in the spring of 2000 . The remaining activated concrete in the underground test vault will then be removed and disposed of as radioactive waste. The remaining hole will then be soil sampled by Rocketdyne as part of a final survey; and ORISE and DHS will then perform verification soil sampling. Assuming results show no residual contamination, the facility will be released for unrestricted use and the excavation backfilled and graded.

\subsection{De Soto Mass Spectrometer Laboratory}

During 1998, the Mass Spectrometer Laboratory at De Soto was remediated. A Rocketdyne final survey was completed in September 1998 (Ref. 16). The ORISE then 
performed a verification survey in September 1998 (Ref. 17) followed by a verification survey by the California DHS. All surveys demonstrated that the facility met DOE and DHS-approved release limits.

\subsubsection{Resource Conservation and Recovery Act}

Under the Hazardous and Solid Waste Amendments of 1984, RCRA facilities can be brought into the corrective action process when an agency is considering any RCRA permit action for the facility. The SSFL was initially made subject to the corrective action process in 1989 by EPA, Region IX. The EPA has performed the Preliminary Assessment Report (i.e., record search) and the Visual Site Inspection portions of the RCRA Facility Assessment process.

The State of California DTSC has RCRA authorization and has become the lead agency in implementing the corrective action process for the SSFL. ETEC has performed soil sampling at various SWMUs and AOCs that were identified in the RFA report. This has enabled ETEC to determine if further action and/or interim measures will be necessary for SWMUs to be incorporated into the RCRA Facility Investigation (see Section 3.1.3).

\subsubsection{Permits and Licenses (Area IV)}

Listed below are the permits and licenses applicable to activities in Area $\mathrm{NV}^{1}$.

\begin{tabular}{|c|c|c|}
\hline Permit/License & Facility & Valid \\
\hline \multicolumn{3}{|c|}{ Air (VCAPCD) } \\
\hline Permit 0271 & Combined permit renewal & $\begin{array}{l}\text { 1/1/98 through } 12 / 31 / 98 \\
1 / 1 / 99 \text { through } 12 / 31 / 99\end{array}$ \\
\hline \multicolumn{3}{|c|}{ Treatment Storage (EPA) } \\
\hline $\begin{array}{l}\text { CAD000629972 } \\
\text { (93-3-TS-002) }\end{array}$ & $\begin{array}{l}\text { Hazardous Waste Management } \\
\text { Facility (T133 and T029) }\end{array}$ & Inactive: closure announced \\
\hline CA3890090001 & $\begin{array}{l}\text { Radioactive Materials Handling } \\
\text { Facility (RMHF) }\end{array}$ & $\begin{array}{l}\text { Part A interim status December } \\
\text { 1997. Application for Part B } \\
\text { submitted May } 1999 \text {. }\end{array}$ \\
\hline \multicolumn{3}{|c|}{ NPDES (CRWQCB) } \\
\hline CA0001309 & Santa Susana Field Laboratory & $6 / 29 / 98$ through $5 / 10 / 03$ \\
\hline \multicolumn{3}{|c|}{ State of California } \\
\hline $\begin{array}{l}\text { Radioactive Materials } \\
\text { License }(0015-19)\end{array}$ & All Rocketdyne facilities & $\begin{array}{l}\text { Amendment } \\
97 \\
98 \\
99 \\
100 \\
101 \\
102 \\
\text { Ongoing }\end{array}$ \\
\hline
\end{tabular}

\footnotetext{
IThe waste discharge requirements for the sewage treatment plan in Area III that receives the Area IV sewage are included in the NPDES permit.
} 
During 1998, 10 underground storage tanks (UST) were exempt from permitting in Area IV. A list of the remaining tanks is shown in Table 3-2.

Table 3-2. SSFL Current Underground Storage Tanks

\begin{tabular}{|c|c|c|c|c|}
\hline $\mathrm{UST}^{\mathrm{C}}$ & $\begin{array}{l}\text { Building } \\
\text { Location }\end{array}$ & $\begin{array}{l}\text { Capacity } \\
\text { (gallons) }\end{array}$ & Tank Type & Contents \\
\hline UT-7 & T022 & 3,000 & Stainless Steel Vaulted & RA water ${ }^{b}$ \\
\hline UT-15 & T022 & 8,000 & Stainless Steel Vaulted & RA water ${ }^{b}$ \\
\hline UT-16 & T021 & 200 & Stainless Steel Vaulted & RA water ${ }^{b}$ \\
\hline UT-29 & T356 & 13,000 & Stainless Steel Vaulted & Sodium $^{c}$ \\
\hline UT-30 & T356 & 10,000 & Stainless Steel Vaulted & Sodium $^{c}$ \\
\hline UT-31 & T356 & 10,000 & Stainless Steel Vaulted & Sodium ${ }^{c}$ \\
\hline UT-32 & T356 & 10,000 & Stainless Steel Vaulted & Sodium $^{c}$ \\
\hline UT-33 & T356 & 12,000 & Stainless Steel Vaulted & Sodium $^{c}$ \\
\hline UT-34 & T462 & 36,000 & Stainless Steel Vaulted & Sodium $^{c}$ \\
\hline UT-35 & T462 & 34,000 & Stainless Steel Vaulted & Sodium $^{c}$ \\
\hline
\end{tabular}




\section{ENVIRONMENTAL PROGRAM INFORMATION}

At SSFL, the Energy Technology Engineering Center (ETEC) has responsibility for the former nuclear facilities and related cleanup operations. ETEC's Environmental Management (EM) department is responsible for environmental restoration and waste management operations in Area IV, where the nuclear operations were conducted. The Department's mission is to "Perform remediation of the ETEC facilities with full regulatory compliance, total regard for personnel safety and protection of the environment, within agreed to budgets and schedules." Supporting the EM department in this work are ETEC's General Support \& Quality Assurance (QA) Department and Rocketdyne's Safety, Health \& Environmental Affairs (SHEA), Transportation, Quality Assurance, Procurement, and Technical Skills Development departments.

Environmental restoration activities at ETEC include decontamination and decommissioning (D\&D) of radioactively contaminated facilities, assessment and remediation of soil and groundwater, surveillance and maintenance of work areas, and environmental monitoring. Waste management activities include waste characterization and certification, storage, treatment, and off-site disposal. Waste management activities are performed at two permitted facilities: the Radioactive Materials Handling Facility (RMHF) for radioactive and mixed waste, and the Hazardous Waste Management Facility (HWMF) for alkali metal waste.

\subsection{ROCKETDYNE ENVIRONMENTAL PROTECTION AND REMEDIATION}

Oversight of the environmental protection at Rocketdyne is the responsibility of the SHEA department, and this department provides support to ETEC for environmental management and restoration. The stated policy of SHEA is "To support the Corporation's commitment to the well-being of its employees, community, and environment. It is Rocketdyne's policy to maintain facilities and conduct operations in accordance with all federal, state, and local requirements and contractual agreements. Rocketdyne employees are responsible for implementing and complying with this policy." Responsibilities for environmental protection at Rocketdyne fall under four subdepartments: Environmental Protection (EP), Environmental Remediation (ER), Radiation Safety (RS), and Environmental Management (EM). ${ }^{2}$ The responsibilities for each are listed below.

Environmental Protection (EP) is responsible for developing and implementing costeffective and efficient programs designed to ensure achievement of the policy objectives related to environmental protection. The EP responsibilities include:

- Ensuring compliance with applicable federal, state, and local rules and regulations, including maintaining a working knowledge of applicable environmental laws, performing compliance audits, reviewing new and modified facility projects, coordinating solid and hazardous waste disposal, maintaining required records, preparing and submitting required regulatory reports, applying for and maintaining permits and assuring compliance with permit conditions, performing sampling and analysis.

${ }^{2}$ In January 1999, Environmental Management was renamed DOE Site Restoration. 
- Responding to uncontrolled releases, and reporting releases as required by law and contractual requirements.

- Suspending operations determined to be in violation of environmental regulations.

- Participating in rule and regulatory development, including evaluating impacts on Rocketdyne programs, coordinating with other Rocketdyne functions, as appropriate, and informing management and staff of new or revised requirements.

- Providing a program, in conjunction with Technical Skills and Development, for motivating, informing, and training employees about their duties to comply with environmental regulations and protect the environment.

- Recognizing and responding to the community's concerns regarding the environmental impact of Rocketdyne operations including escorting and cooperating with regulatory officials interested in environmental matters and responding to requests for information referred to Communications.

- Working with Rocketdyne customers and suppliers to minimize the use of materials and processes that impact the environment while maintaining product quality and competitive pricing.

- Making environmental concerns, energy and raw material conservation a priority when evaluating new and existing operations and products or when making decisions regarding land use, process changes, materials purchases, and business acquisitions.

Radiation Safety (RS) is responsible for providing radiological support for the D\&D of radiological contamination at all Rocketdyne facilities. The RS responsibilities include:

- Compliance with all federal, state, and local regulations pertaining to occupational and environmental radiation protection.

- $\quad$ Provision of health physics oversight of $D \& D$ and radioactive waste management activities.

- Performance of final surveys of D\&D'ed buildings and facilities to demonstrate acceptability for release for unrestricted use.

- Response to employee and public concerns regarding radiological activities and the impact of these activities on the health and safety of the community.

Environmental Remediation (ER) is responsible for remedial actions to clean up historical chemical contamination at all Rocketdyne facilities. The ER responsibilities include:

- Compliance with all federal, state, and local regulations pertaining to environmental remediation.

- Remediation of historical chemically contaminated Rocketdyne sites to achieve closure. 
- Implementation of groundwater monitoring and treatment.

- Implementation of RCRA soil sampling and cleanup activities.

Environmental Management (EM) is responsible for performing the "hands on" D\&D of former DOE nuclear and liquid metal test facilities in support of the ETEC Closure program. DOE Site Restoration responsibilities also include:

- Responsibility for the management and shipment of radioactive waste, generated during the D\&D operations, to DOE-approved disposal sites.

- Operation of the Radioactive Materials Handling Facility (RMHF) under an interim status Part A permitted facility for the management of mixed (radioactive and hazardous) wastes.

- Coordination of activities with specialty contractors used to support D\&D activities including asbestos and lead abatement, recycling of sodium from former liquid metal facilities, and demolition of structures following removal of hazardous materials and components.

- Performance of the routine Surveillance and Maintenance (S\&M) activities for DOEowned facilities to ensure that the buildings are properly maintained such that the buildings do not create personnel or environmental safety hazards.

- Responsibility for identifying, removing, staging, and initiating documentation for DOE equipment being divested.

\subsection{ENVIRONMENTAL MONITORING PROGRAM}

The purpose of the environmental monitoring program is to detect and measure releases of hazardous and radioactive materials and identify other undesirable impacts on the environment. It includes remediation efforts to correct or improve contaminated conditions at the site and prevent off-site effects. For this purpose, the environment is sampled and monitored, and effluents are analyzed. A goal of this program is to demonstrate compliance with applicable regulations and protection of human health and the environment. Environmental restoration activities at the SSFL include a thorough review of past programs and historical practices to identify, characterize, and correct all areas of potential concern. The key regulations governing the monitoring program are DOE Orders 5400.1 and 5400.5 (Refs. 19 and 20). Additional guidance is drawn from California regulations and licenses, and appropriate standards.

The basic policy for control of radiological and chemical materials requires that adequate containment of such materials be provided through engineering controls, that facility effluent releases be controlled to federal and state standards, and that external radiation levels be reduced to as low as reasonably achievable (ALARA) through rigid operational controls. The environmental monitoring program provides a measure of the effectiveness of these operational procedures and of the engineering safeguards incorporated into facility designs. 


\subsubsection{Radiological Monitoring}

The radiological monitoring program involves measurements of radioactivity in air, soil, surface water, groundwater, and vegetation, and environmental and facility radiation, as appropriate to the changing conditions at the site.

Samples of particulate matter in facility ventilation exhausts and the ambient air are collected by means of filters and vacuum pumps. Facility atmospheric effluent sample filters and ambient air sample filters for 1998 were composited from each sampler for radiochemistry analysis by Teledyne Brown Engineering. Gamma-spectrometer analyses of samples such as soil, water, and ambient air sample filters confirm that the major radionuclides present are normally those of the naturally occurring thorium and uranium decay chains, plus other natural radionuclides such as the primordial $\mathrm{K}-40$, and $\mathrm{Be}-7$ produced by cosmic ray interactions in the atmosphere.

Ambient radiation is monitored at facility boundaries and throughout Area IV, as well as at the De Soto facility, with thermoluminescent dosimeters. These verify that all dose rates and public doses are within regulatory limits.

In addition to environmental monitoring, workplace air and atmospheric effluents are continuously monitored or sampled, as appropriate. This directly measures the effectiveness of engineering controls and allows remedial action to be taken before a significant release of radioactivity could occur.

\subsubsection{Non-Radiological Monitoring}

Extensive monitoring programs for chemical contaminants in air, soil, surface water, and groundwater are in effect to assure that the existing environmental conditions do not pose a threat to the public welfare or environment. Soils contaminated by petroleum products are remediated whenever underground fuel tanks are removed. Extensive soil sampling is performed under the Resource Conservation and Recovery Act Facility Investigation and other site-specific remedial programs. Groundwater beneath Area $\mathrm{N}$ is extensively monitored for chemical contaminants through sampling at 45 on-site and off-site wells. Groundwater analyses were conducted by Groundwater Resources Consultants, Inc. (GRC) following a DTSC-approved sampling and analysis plan and approved EPA analytical methods. Equipment installed in an interim groundwater remediation program in Area IV removed solvents from contaminated groundwater at a throughput of about 118,000 gallons per month in 1998. This system returned remediated water to the surface water collection ponds.

All surface water discharges are monitored as specified in the existing National Pollutant Discharge Elimination System permit. The National Pollutant Discharge Elimination System (NPDES) permit was renewed in 1998. In addition, all sources of emissions are monitored as required by the Ventura County Air Pollution Control District. Asbestos control is conducted under the requirements of Titles 29, 40, and 49 of the Code of Federal Regulations (CFR), in addition to any state or local regulations that apply to any specific asbestos abatement program.

In addition to this environmental monitoring and restoration program, current operational procedures reflect Rocketdyne's commitment to a clean and safe environment. For example, 
solvents and oils are collected and recycled, rather than being discarded. A comprehensive training and employee awareness program is in place. All employees working with hazardous materials are required to attend a course on hazardous materials waste management. Environmental bulletins are printed in the internal Rocketdyne newspaper to promote environmental awareness among all employees.

\subsection{ENVIRONMENTAL TRAINING}

Rocketdyne conducts training and development programs as an investment in human resources to meet both organizational and individual goals. These programs are aimed toward improving employee performance, assuring employee proficiency, preventing obsolescence in employee capability, and preparing employees for changing technology requirements and for possible advancement.

The People \& Communications Organization is responsible for the development and administration of formal training and development programs. Process managers are responsible for individual employee development through formal training, work assignments, coaching, counseling, and performance evaluation. Process managers and employees are jointly responsible for defining and implementing individual training development goals and plans, including on-the-job training.

The Rocketdyne Training and Development Department currently maintains a listing of approximately 700 courses available for Rocketdyne personnel. Of these, approximately 102 relate to environment, health, and safety, with approximately 10 relating to environmental protection, 10 to radiation safety and remediation, and 82 to health and safety. Specialized training programs on new technological developments and changes in regulations are provided, as needed, to assure effective environmental protection and worker health and safety. Also, informal discussions about waste minimization and management occur at hazardous waste coordinator's meetings. Additional off-site courses are also encouraged.

\subsection{WASTE MINIMIZATION AND POLLUTION PREVENTION}

\subsubsection{Program Planning and Development}

A Waste Minimization and Pollution Prevention Awareness Plan developed in accordance with DOE Order 5400.1 (Ref. 19) has been in place since December 1993. The plan was updated (Ref. 21) during 1996 to include DOE's guidelines for waste minimization during ER activities. This plan serves as a guidance document for all waste generators at the ETEC. The plan emphasizes management's proactive policy of waste minimization and pollution prevention, and outlines goals, processes, and waste minimization techniques to be considered for all waste streams generated at the former ETEC. The plan requires that assessments of all major restoration projects be performed to identify waste minimization opportunities and implement all cost-effective waste reduction options.

The majority of waste currently generated at the former ETEC is attributable to environmental management activities related to environmental restoration of surplus facilities and clean up of contaminated sites from previous programs. The key components of waste generated at ETEC are: 
- Low-level radioactive waste (LLW), mixed, hazardous, and non-hazardous wastes from D\&D operations.

- Sodium and NaK-contaminated components from D\&D operations at the former sodium facilities.

- Oils from ongoing remediation activities.

- Solvents and paints.

In general, the measures used to promote waste minimization at ETEC are:

- Using comprehensive segregation and screening procedures to minimize mixed wastes by separating LLW and hazardous wastes.

- Using survey and decontamination processes to release concrete and steel for potential recycling/reuse

- Removing bulk sodium from facility drain tanks for recycling/reuse.

- Converting residual sodium in piping and components to high-grade sodium hydroxide for commercial use

- Sampling, analyzing, and filtering oils to extend their useful life and reduce oil consumption.

- Reusing containers of radioactive LLW for storage.

- Linking of a chemical/material exchange system with the purchasing system to reduce purchases of hazardous materials.

- Reducing non-hazardous waste disposal through process changes and recycling.

- Using/operating improved air filtration technology in decontamination facility to minimize generation of filter media wastes.

Waste minimization is accomplished by first assessing the waste, identifying waste minimization options, and finally conducting technical and economic evaluations to determine the best approach.

\subsubsection{Training and Awareness Programs}

The ETEC Waste Minimization and Pollution Prevention Awareness Program includes (1) orientation programs and refreshers, (2) specialized training, and (3) incentive awards and recognition. New ETEC employees attend an orientation program that describes waste generation, treatment, disposal, minimization, and pollution prevention. Orientation presentations are designed to increase pollution prevention and waste minimization awareness and to motivate employees. 
Employees are reminded about pollution prevention and waste minimization awareness. Posters are placed in work areas to notify employees about environmental issues or practices. Memoranda are circulated about changes in waste management policy, Rocketdyne policies or procedures, and technical data relevant to an employee's job assignment. Presentations using visual aids are provided, as needed, to review major changes in environmental issues.

\subsubsection{Waste Minimization and Pollution Prevention Activities}

The following are some significant activities related to waste minimization and pollution prevention.

- $\quad$ Perform sampling, analysis, and filtering of motor/turbine oils prior to servicing. These procedures have greatly extended the life of these oils and saved money particularly when synthetic oils are involved.

- Use comprehensive segregation and screening procedure of RA materials resulting in the salvage of usable non-radioactive scrap metal.

- A chemical/material exchange system is currently linked to the purchasing system and prevents the unnecessary purchase of hazardous materials.

- All hazardous waste containers in acceptable condition are reused. Similar hazardous wastes are combined during pickup runs.

- Empty product drums returned to the vendor for reuse when practical.

- Approximately $80 \%$ of the white paper (5.5 metric tons) and aluminum cans (2.0 metric tons) are recycled as a result of increased environmental awareness.

- Use of a compactor to reduce the volume of soft low-level RA waste with 5 to 15 compaction ratios (soft trash limited to two boxes during 1998).

- $\quad$ Size reduction and repackaging achieved significant RA waste reduction. These activities resulted in a waste reduction of approximately $4,000 \mathrm{ft}^{3}$ of LLW during 1998.

- Operation of a Torit self-cleaning filter unit in a radiological decontamination facility eliminated waste consisting of about 120 used prefilters annually that would have been generated using a conventional unit.

- Approximately 55,000 pounds of residual sodium in tanks and piping systems was converted into commercial-grade sodium hydroxide using a WVN process. This resulted in avoiding generation of approximately 12,000 gallons of hazardous waste during 1998.

- Approximately 201,000 pounds of bulk sodium was transferred for reuse $(107,000$ off-site and 94,000 pounds on-site). 
- Approximately 15 metric tons of clean recyclable stainless steel, 355 metric tons of carbon steel, and 0.3 metric ton of lead resulted from divestment activities.

- Cost-effective decontamination practices resulted in the reuse of a backhoe tractor, and six 1,800-gallon water tanks, and recycling of a 3,000-lb forklift battery.

- Implementation of the waste minimization assessment for the D\&D of the Hot Lab (Bldg. 4020) resulted in the reduction and release for reuse (by decontamination and survey) of 1,360 metric tons of concrete during 1998.

\subsubsection{Tracking and Reporting System}

Various categories of materials from procurement to waste disposal are tracked. Radioactive and mixed wastes are characterized sufficiently (for safe storage) by the generator, transferred to the RMHF, and logged and temporarily stored at the RMHF. Documents that accompany the wastes are verified for accuracy and completeness, and filed at the RMHF. Hazardous waste tracking and verification procedures (from generator to final off-site disposal) are followed by the Environmental Protection department. Rocketdyne is responsible for all non-hazardous and sanitary waste operations at the SSFL.

Relevant reports include:

- $\quad$ EPA's Biennial Hazardous Waste Report

- DOE's Annual Waste Minimization Report

- DOE's Affirmative Procurement Report

- "Source Reduction Evaluation Review and Plan" and "Hazardous Waste Management Performance Report," both of which are required by the "Source Reduction and Hazardous Waste Management Review Act (SB14)" 


\section{ENVIRONMENTAL RADIOLOGICAL MONITORING}

Radiological monitoring of the environment at SSFL began before the first nuclear facilities were established in 1956. The program has continued with modifications to suit the changing operations. The selection of monitoring locations was based on several site-specific parameters such as topography, meteorology, hydrology, and the location of nuclear facilities. The prevailing wind direction for the SSFL site is generally from the north and northwest, with some seasonal diurnal shifting to the southeast quadrant. Most rainfall runoff at the SSFL site flows through several natural watercourses and drainage channels and is collected in two largecapacity retention ponds. This water may be discharged off-site into Bell Creek to the south or it may be reused for industrial purposes.

Gross alpha and beta measurements of ventilation exhaust and ambient air samples are used for screening purposes to quickly identify any unusual release, and to permit a long-term historical record of radioactivity in the environment. These samples are also analyzed annually for specific radionuclides. Detailed analyses of these samples permit more accurate estimates of the potential off-site dose for the air pathway. For surface water and groundwater, gross alpha and gross beta analysis also permits direct comparison with the screening limits established by EPA for suppliers of drinking water. EPA regulations require more detailed analysis if these limits are exceeded. The following discussion presents a brief summary of pathway dose analysis results for SSFL and De Soto for 1998.

Direct radiation is monitored by the use of 59 thermoluminescent dosimeters (TLDs) mounted on facility fencelines and along the site boundary. To permit the most accurate measurement of low levels of ambient radiation, 18 of these are very sensitive "sapphire" TLDs. These TLDs are complemented by TLDs installed by the State of California Department of Health Services Radiologic Health Branch for independent surveillance. Additional standard TLDs are located around and throughout the facilities.

\subsection{DOE FACILITIES AT SSFL (AREA IV)}

The RMHF and Buildings 4024 and 4059 have continuous effluent monitoring capability. In 1998, effluent was monitored only for the RMHF and Building 4024 since no radiological work in Building 4059 required portable filtered exhaust use during the year. The decontamination of several buildings was completed. Buildings 4023, 4011, 4363, and area 4886 were released for unrestricted use by the DHS/RHB in 1998. Airborne releases from the RMHF (Table 5-1, Sheet 1) are shown to be below the Derived Concentration Guides (DCGs) of DOE Order 5400.5 (Ref. 20). Airborne radiation doses from the RMHF and Building 4024 are detailed in Table 5-1 and are shown to be below the dose limits of DOE Order 5400.5 and EPA NESHAPs limits of 40 CFR 61, Subpart H. Key results are discussed below. 
Table 5-1. Atmospheric Effluents to Uncontrolled Areas (Sheet 1 of 3)

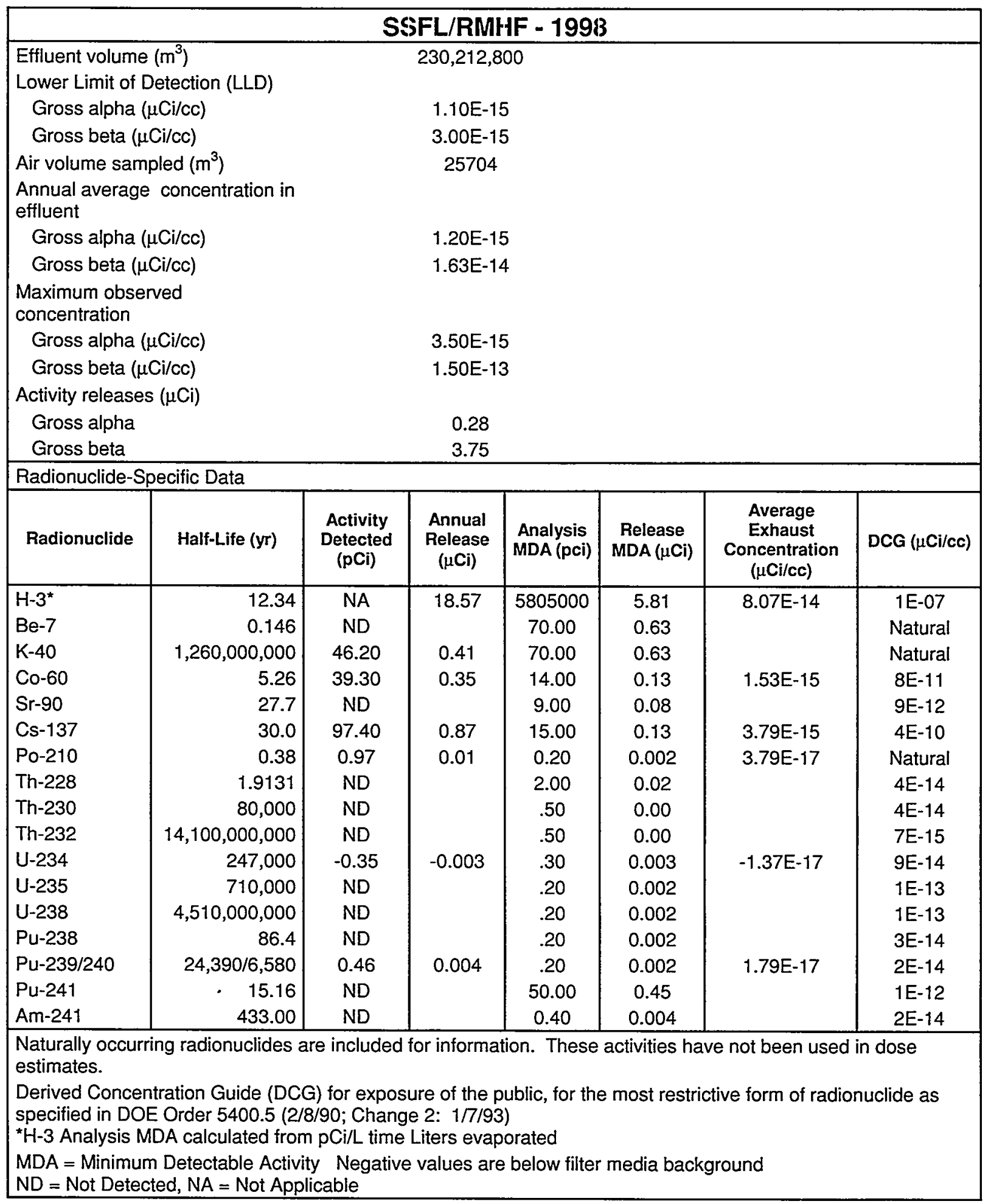


Table 5-1. Atmospheric Effluents to Uncontrolled Areas

(Sheet 2 of 3)

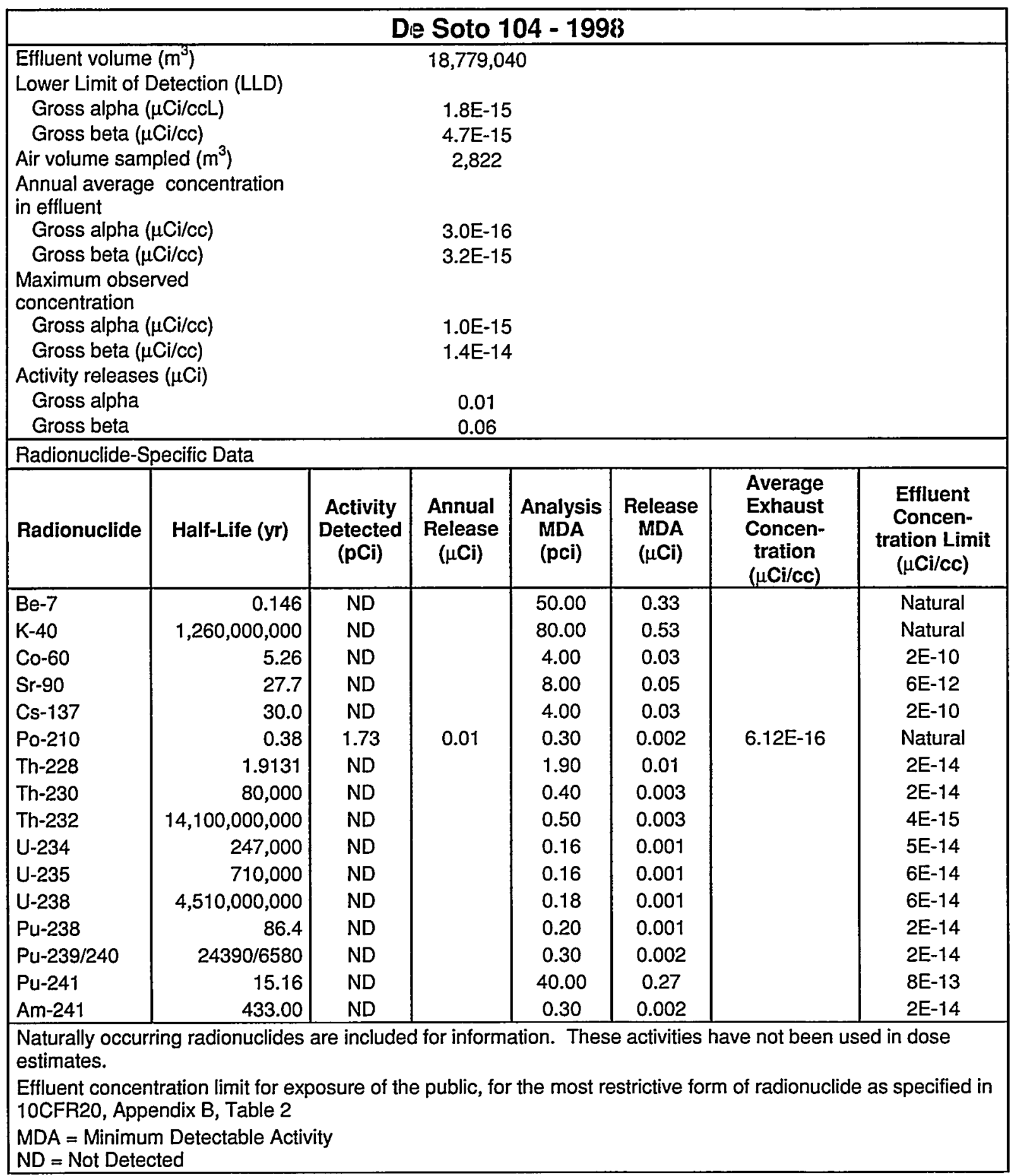


Table 5-1. Atmospheric Effluents to Uncontrolled Areas (Sheet 3 of 3)

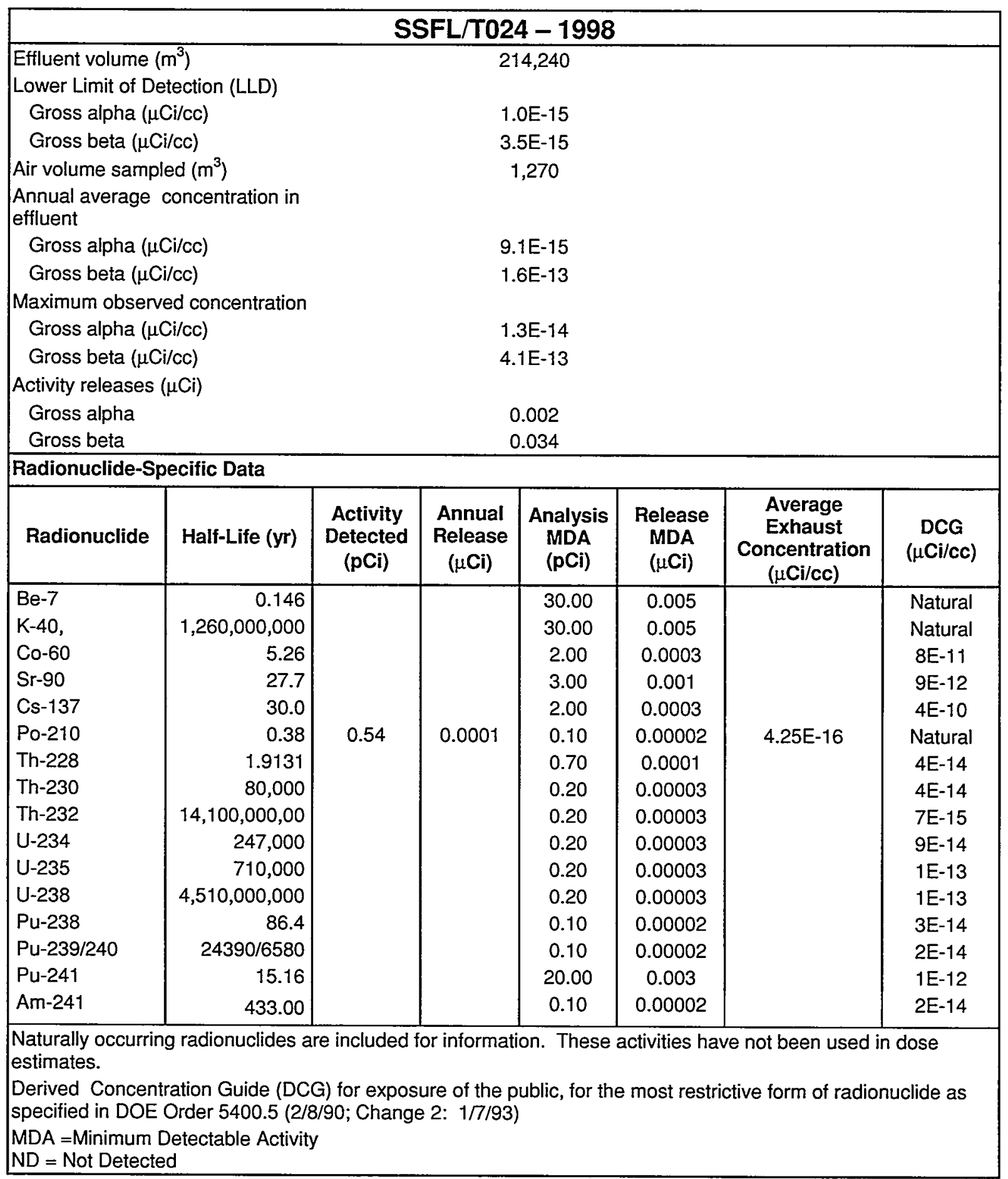




\subsubsection{Direct Radiation}

At the old site boundary-line location nearest to the RMHF, the external annual exposure from direct radiation is calculated to correspond to an average annual dose of approximately $48 \mathrm{mrem}$ above natural background (equivalent to $5.5 \mu \mathrm{R} / \mathrm{hr}$ ). In February 1998, the SSFL boundary was moved several hundred feet to the north. Intervening cliffs effectively shield any direct radiation from RMHF to zero mrem/yr at the new site boundary, below the DOE long-term limit of $100 \mathrm{mrem} / \mathrm{yr}$ as specified in DOE Order 5400.5 "Radiation Protection of the Public and the Environment." State and NRC regulations impose the same limits for licensed operations.

For the nearest residence, radiation attenuation by the air reduces direct radiation to levels indistinguishable from normal background. In addition, intervening rock formations and hills completely shield off-site locations from the radiation sources. Essentially only natural background radiation inherent to the residence location would actually be present.

\subsubsection{Airborne Radioactivity}

Airborne dose calculations were performed to demonstrate compliance with the NESHAPs standard. At the location of the hypothetical Maximally Exposed Individual, the effective dose equivalent from DOE facility exhaust during 1998 (RMHF) was $1.3 \times 10^{-6}$ mrem. The EPA limit for a DOE site is $10 \mathrm{mrem} / \mathrm{yr}$, as specified in $40 \mathrm{CFR}$ 61, Subpart $\mathrm{H}$. Potential releases from the RMHF are so low that, even assuming absence of HEPA filters, estimated doses would be below the level requiring continuous monitoring. However, continuous monitoring is still being performed as a best management practice.

In addition to the above point source, analyses were performed to determine the maximum estimated individual dose due to potential releases from "area" sources. The only area sources considered for 1998 are two small areas adjacent to the 4064 sideyard, the Hot Lab Liquid Waste Holdup Building excavation area, the $17^{\text {th }}$ street drainage area, and the RMHF pond (Sump 614), which was dry during 2 weeks in 1998, because all were subject to possible resuspension of sediment by the wind. The RMHF North Slope has been considered to be an occasional source in prior years but is now fully covered by native vegetation, and thus no wind borne resuspension of radioactively contaminated soil can occur.

The estimated dose to the hypothetical maximum exposed individual due to potential releases from the diffuse area sources only is $2.5 \times 10^{-3} \mathrm{mrem}\left(2.5 \times 10^{-5} \mathrm{mSv}\right)$ for 1998 . The estimate is higher than prior years because of the elevated levels of thorium found at the $17^{\text {th }}$ Street Drainage Area site (6.2 pCi/g max) (our site-wide release criteria is $5.0 \mathrm{pCi} / \mathrm{g}$ ). The numbers were reran with normal natural levels of thorium $(\sim 1 \mathrm{pCi} / \mathrm{g})$, which would not be required, and the exposure decreased to $7.5 \times 10^{-4}$ mrem $\left(7.5 \times 10^{-6} \mathrm{mSv}\right)$. With no thorium, the number would have been $6.2 \times 10^{-5} \mathrm{mrem}\left(6.2 \times 10^{-7} \mathrm{mSv}\right)$. This shows that a small amount of thorium, even at natural levels, greatly influences the dose calculated. Since releases from the area sources were too small and diffuse to permit accurate measurements, potential releases were estimated using the same method used in the RESRAD (Ref. 22) computer program (ANL/ES-160), for calculation of airborne radioactivity due to resuspension of soil by the wind. These estimated releases were used as input in the CAP88-PC program to perform the area source dose assessments. Releases from these sources have not been detectable by on-site continuous ambient air sampling except for the Sump 614 air sampling monitor that indicated $\mathrm{Pu}-238 / 239 / 240$, the sum of fractions equal to 
0.013 DCGs when compared to the limits of DOE Order 5400.5 (limit $=1.0$ ), and the Hot Lab 4468 excavation filters, which showed Cs-137 at a level of 0.0006 DCGs.

At the boundary-line location nearest to the Hot Lab, the external annual exposure from direct radiation is indistinguishable from natural background as was the dose for the nearest residence. The value for the DOE long-term limit is $100 \mathrm{mrem} / \mathrm{yr}$ as specified in DOE Order 5400.5. The basement at the Hot Lab was demolished in 1997 and the facility ventilation unit was shut down during the first week of May 1997, so airborne dose calculations were not required.

Building 4024 was used as a staging and decontamination area for the Hot Lab concrete blocks, earlier extracted from the building during remediation activities. A portable tent was set up with a portable HEPA ventilation system providing negative pressure inside the tent during block decontamination. This HEPA unit exhausted to the outside environment and was monitored in a manner similar to the monitoring done at facility stacks. Detailed analysis of the filters indicated no man-made radioisotopes and the dose, at the site boundary and nearest resident, was therefore zero.

Airborne releases from Building 4024 are detailed in Table 5-1, Sheet 3, and as shown, only Po-210, a natural isotope was present. Weekly gross alpha and beta analysis of the filters showed the exhaust air was well below the DCGs of DOE Order 5400.5.

\subsection{STATE OF CALIFORNIA LICENSED FACILITY AT DE SOTO-BUILDING 104}

Airborne releases from Building 104 at the De Soto facility are detailed in Table 5-1, Sheet 2 , and are shown to contain only natural radioactive isotopes. The dose at the site boundary is therefore zero. Airborne and direct radiation doses at the site boundary are detailed in Table 5-13 and are shown to be less than the dose limits of 10CFR20.1301, as referenced by State of California, CCR Title 17, Section 30253. (This facility was operated for DOE under a State of California license.) The ventilation unit was demolished during the 1998 remediation project and 1998 was the last year airborne effluents required monitoring.

Direct radiation measurements at De Soto were typical of background measurements, both on-site and off-site. Airborne effluent from Building 104 were not calculated because detailed analysis of the filters indicated no man-made radioactive isotopes and the dose was therefore $0 \mathrm{mrem} / \mathrm{yr}$. The EPA NESHAPs limit is $10 \mathrm{mrem} / \mathrm{yr}$ from $40 \mathrm{CFR} 61$, Subpart H, for DOE facilities. Compliance with 40 CFR 61, Subpart I, applicable to licensed facilities, using the COMPLY code was not required at a $0 \mathrm{mrem} / \mathrm{yr}$ dose level.

\subsection{EFFLUENT MONITORING}

Workplace ventilation is provided in all areas where unencapsulated or unpackaged radioactive material is handled, such as in the 4024 Hot Lab satellite area and in the decontamination and packaging rooms at RMHF (where equipment is decontaminated and radioactive waste is repackaged). This assures protection of the workers from inhalation of airborne radioactive material and prevents the spread of radioactive contamination into the adjacent clean areas. The ventilation exhaust is passed through HEPA filters before being discharged to the atmosphere, to prevent the release of airborne radioactivity. The filtered air 
generally contains lower levels of long-lived radioactivity than does ambient air from naturally occurring radionuclides in the atmosphere. Essentially all short-lived radioactivity in the air is caused by natural Be-7 and the naturally present radon daughters, which dominate the airborne activity.

The ventilation exhaust is sampled to measure the effluent radioactivity. Data from this sampling is used to demonstrate compliance with State DHS/RHB, DOE, and EPA (NESHAPs) standards. The U.S. EPA regulates airborne releases of radioactivity from DOE facilities under 40 CFR 61, Subpart H, and from licensed facilities under 40 CFR 61, Subpart I.

The only potential release of effluent radioactivity to uncontrolled areas is by way of filtered discharge of ventilation exhaust from the RMHF, 4059, 4024 tent, and Building 104, and occasional diffuse area sources. No contaminated liquids are discharged to uncontrolled areas. No activities requiring facility ventilation were conducted in 4059 during 1998 . The only diffuse area sources considered significant for 1998 are a temporarily dry runoff collection sump for the RMHF, suspended soil during an excavation adjacent to the 4064 side yard, suspended soil during the Hot Lab 4468 excavation, and suspended soil during remediation related excavation at the $17^{\text {th }}$ street drainage area.

The level of radioactivity contained in all atmospheric effluents is reduced to the lowest practical value by passing the effluents through certified HEPA filters. The effluents are sampled for particulate radioactive materials by means of continuously operating stack exhaust samplers at the point of release. In addition, the stack monitor installed at the RMHF provides automatic alarm capability in the event of the release of particulate activity. The HEPA filters used for filtering atmospheric effluents are at least $99.97 \%$ efficient for particles $0.3 \mu \mathrm{m}$ in diameter.

The average concentration and total radioactivity, as gross alpha and gross beta activity, in atmospheric effluents to uncontrolled areas from the RMHF, 4024, and De Soto 104 are shown in Table 5-1. The total shows that no significant quantities of radioactivity were released in 1998. The gross alpha and gross beta counts are done shortly after the weekly stack sample is collected, to permit identification of any unusual release. These results include the naturally occurring radionuclides present in air, Be-7, K-40, and Po-210. Detailed analyses are performed on the entire sets of filter samples at the end of the year, to provide the greatest analytical sensitivity.

The isotopic composition of the radioactivity deposited on the nuclear facility exhaust air sampling filters, composited for the year, is also presented in Table 5-1. Gamma-emitting radionuclides were measured by using a high-resolution gamma spectrometer. All others were measured by using specific chemical separations followed by alpha or beta counting and electrolytic enrichment of tritium followed by liquid scintillation counting. Radionuclides that were reported as less than the method detection level are shown as "not detected" (ND). The Po-210 collected on the filters is due to naturally occurring elements from the U-238 decay chain in the environment. The $\mathrm{K}-40$ is due to the presence of this radionuclide in natural potassium of the airborne dust in the ambient air. Be-7 had decayed below the detection level by the time of the analysis. Materials used in operations conducted at the SSFL and De Soto sites are responsible for the fission/activation product radioactivity. 
For each radionuclide detected, the laboratory calculates minimum detectable activity (MDA). This is the lowest activity that would be identified as "detected" with $95 \%$ confidence. For the purpose of comparing effluent releases, the laboratory MDA for the composited filters was converted to an equivalent annual release and is shown in the table as the release MDA.

The concentrations in the effluent at the exhaust stack for each facility are compared with appropriate limits for exposure of the public. The isotopic limits for DOE facilities are DCGs for exposure of the public for the most restrictive form of the radionuclide as specified in DOE Order 5400.5. Isotopic effluent limits for facilities with State of California-licensed activities are Effluent Concentration Limits (ECLs) for release to an unrestricted area for the most restrictive form of the radionuclide as specified in 10 CFR 20, Appendix B.

The most restrictive ECL (from 10 CFR 20 as referenced by CCR 17) or DCG for each radionuclide is shown in column 2 in Table 5-2. (The natural radionuclide K-40 is so uniformly present, and so rarely present in an enriched form, that no ECL or DCG has been developed for it.) These values refer to the permissible concentrations allowed by the State of California and the DOE for continuous exposure of the public. Note that, in all cases, for the exhaust air, the observed concentrations are far below the ECL and DCG. Furthermore, dilution and dispersion occur before the material reaches an unrestricted area, even further reducing the concentration in the public area.

The downwind concentration of radioactive material emissions to the atmosphere during 1998 from the RMHF exhaust stack has been calculated with the CAP88-PC computer code using representative input data including wind speed, directional frequency, and stability (using meteorological data developed for the SSFL site by the NRC and Argonne National Laboratory [ANL]) plus facility-specific data such as stack heights and exhaust air velocity.

The radioactivity concentrations at the site boundary location nearest to each release point and at the nearest residence for each nuclear facility are shown in Table 5-3. These concentrations were estimated by use of CAP88-PC and specific radionuclide releases for each facility, for the direction in which the concentrations are the greatest. As mentioned earlier, no man-made radioactive isotopes were found in the De Soto filter set, and the dose was therefore $0 \mathrm{mrem} / \mathrm{yr}$. While the new SSFL site boundary is 153 meters from the RMHF, the maximum ground level concentration occurs at a distance of 325 meters. Therefore, the concentration for the RMHF is calculated for this distance. 
Table 5-2. Filtered and Ambient Air Radioactivity Concentrations-1998

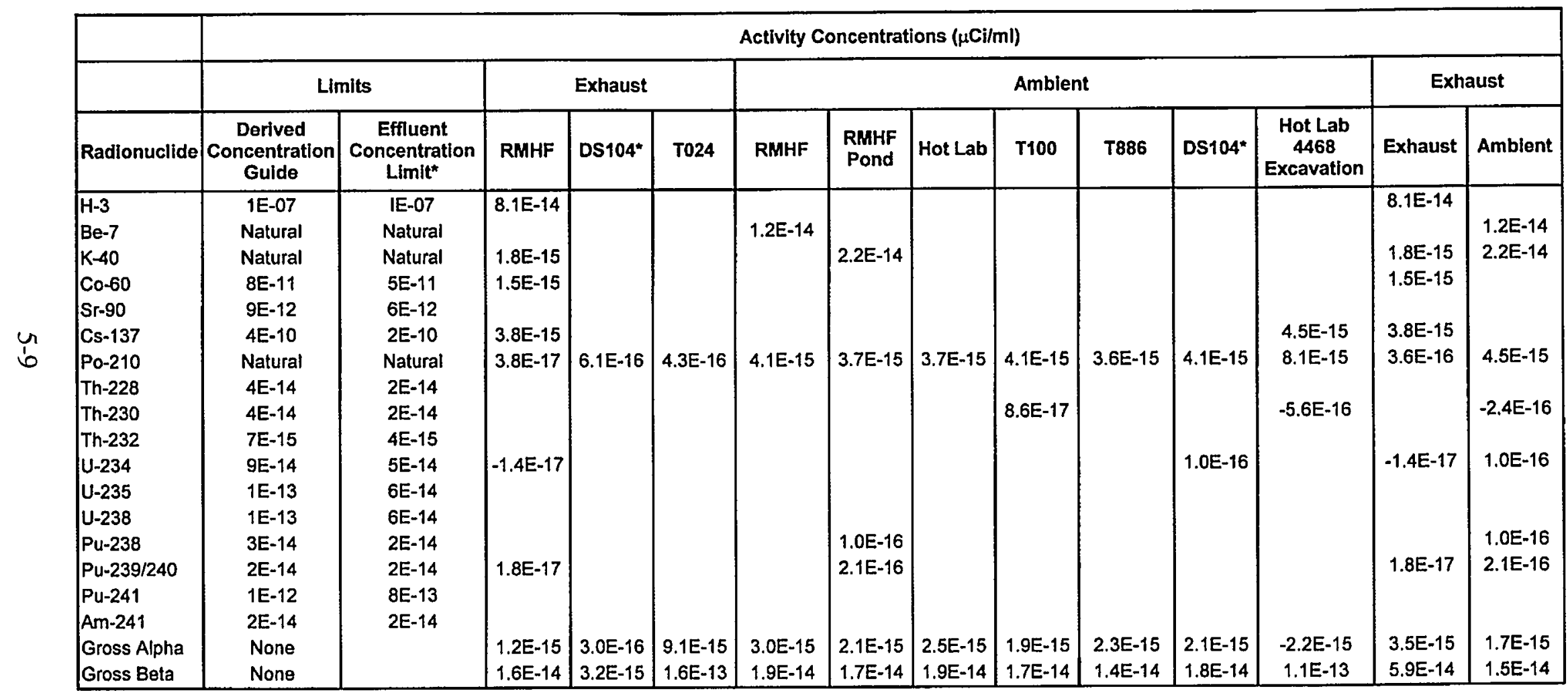


Table 5-3. Annual Average Radioactivity Concentrations of Atmospheric Effluents-1998

\begin{tabular}{|c|c|c|c|c|c|}
\hline \multirow{2}{*}{ Facility } & \multirow{2}{*}{$\begin{array}{c}\text { Annual } \\
\text { Release } \\
\end{array}$} & & \multicolumn{2}{|c|}{$\begin{array}{c}\text { Distance }(\mathrm{m}) \text { and } \\
\text { Direction to }\end{array}$} & \multicolumn{2}{c|}{$\begin{array}{c}\text { Downwind Concentration } \\
(\mu \mathrm{Ci})\end{array}$} & Boundary & Residence & Boundary & Residence \\
\cline { 3 - 6 } & 0 & $187 \mathrm{E}$ & $315 \mathrm{~S}$ & 0 & 0 \\
\hline DS 104 & 0 & $325 \mathrm{NW}$ & $2,867 \mathrm{NW}$ & $1.92 \mathrm{E}-18$ & $1.81 \mathrm{E}-19$ \\
\hline RMHF and 4024 & 19.8 & &
\end{tabular}

\subsection{ENVIRONMENTAL SAMPLING}

\subsubsection{Air}

Ambient air sampling is performed continuously at De Soto and SSFL with air samplers operating on 7-day sampling cycles. In 1998, four additional samplers were operated on a shiftby-shift basis at the Hot Lab during the 4468 (liquid waste tank building) demolition and soil excavation operations. Monitoring locations used in 1998 are shown in Figures 5-1 and 5-2 and listed in Table 5-4. Airborne particulate radioactivity is collected on glass fiber (Type A/E) filters that are changed weekly at the end of each sampling period. The samples are counted for gross alpha and beta radiation following a minimum 120-hour decay period to allow for decay of short-lived radon and thoron daughters. The volume of a typical weekly ambient air sample is approximately $50.4 \mathrm{~m}^{3}$.

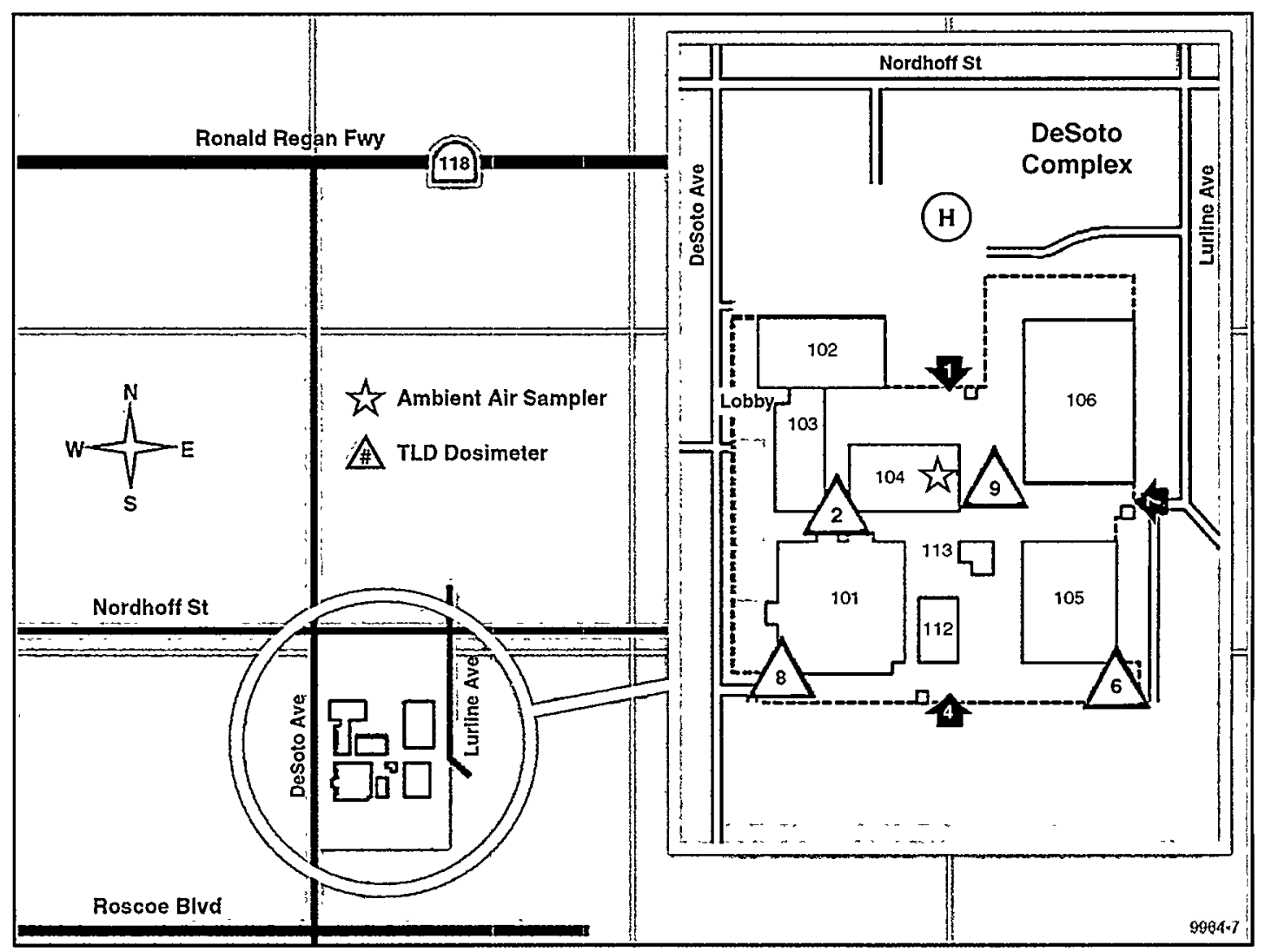

Figure 5-1. Map of De Soto Site Monitoring Stations 
RD99-115

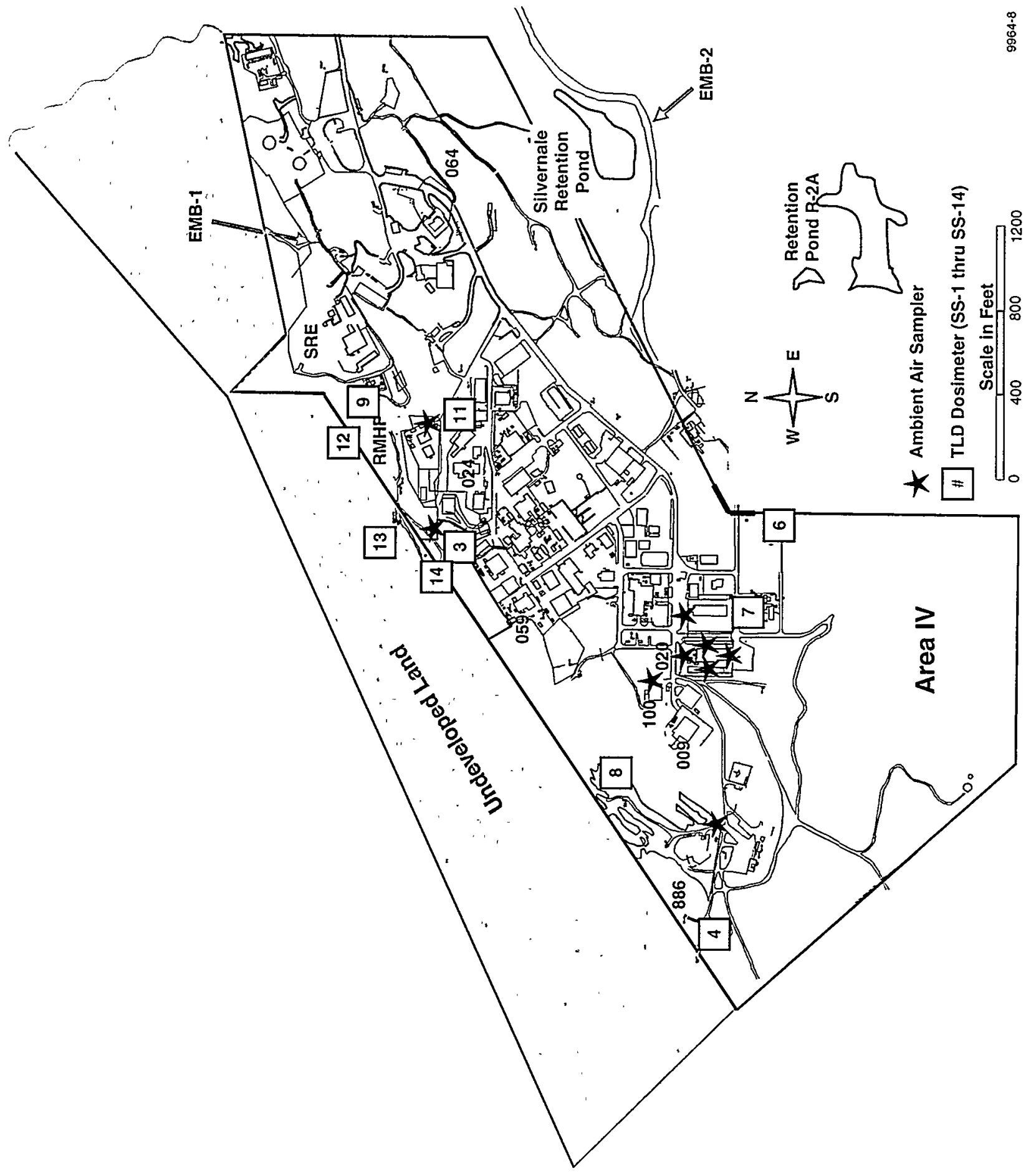

Figure 5-2. Map of Santa Susana Field Laboratory Area IV Sampling Stations 
Table 5-4. Sampling Location Description

\begin{tabular}{|c|c|c|c|}
\hline Station & \multicolumn{2}{|c|}{ Location } & $\begin{array}{l}\text { Sampling } \\
\text { Frequency }\end{array}$ \\
\hline \multicolumn{3}{|c|}{ Ambient Air Sampler Locations } & \\
\hline$A-1$ & \multicolumn{2}{|c|}{ De Soto Site, Building 104 roof } & $(W)$ \\
\hline$A-2$ & \multicolumn{2}{|c|}{ SSFL Site, 4020, northeast of site } & (W) \\
\hline$A-3$ & \multicolumn{2}{|c|}{ SSFL Site, 4034 , at main gate } & (W) \\
\hline A-4 & \multicolumn{2}{|c|}{ SSFL Site, 4886, Former Sodium Disposal Facility } & (W) \\
\hline$A-5$ & \multicolumn{2}{|c|}{ SSFL Site, RMHF Pond, north side } & (W) \\
\hline$A-6$ & \multicolumn{2}{|c|}{ SSFL Site, 4100 , east side } & (W) \\
\hline$A-7$ & \multicolumn{2}{|c|}{ SSFL Site, Hot Laboratory 4468 , north side } & (W) \\
\hline$A-8$ & \multicolumn{2}{|c|}{ SSFL Site, Hot Laboratory 4468 , south side } & (W) \\
\hline$A-9$ & \multicolumn{2}{|c|}{ SSFL Site, Hot Laboratory 4468 , east side } & (W) \\
\hline$A-10$ & \multicolumn{2}{|c|}{ SSFL Site, Hot Laboratory 4468, west side } & (W) \\
\hline \multicolumn{4}{|c|}{ On-site - De Soto - Ambient Radiation Dosimeter Locations } \\
\hline DS-2 & \multirow{4}{*}{\multicolumn{2}{|c|}{$\begin{array}{l}\text { De Soto Site, northwest corner of Building } 101 \\
\text { De Soto Site, east boundary, southeast corner of Building } 105 \\
\text { De Soto Site, Guard Post 4, southwest corner of Building } 101 \\
\text { De Soto Site, southeast of Building } 104\end{array}$}} & (Q) \\
\hline DS-6 & & & (Q) \\
\hline DS-8 & & & (Q) \\
\hline DS-9 & & & (Q) \\
\hline \multicolumn{4}{|c|}{ On-site - SSFL - Ambient Radiation Dosimeter Locations } \\
\hline SS-3 (CA) & \multicolumn{2}{|c|}{ SSFL Site, Electric Substation 719 on boundary fence } & (Q) \\
\hline SS-4 (CA) & \multicolumn{2}{|c|}{ SSFL Site, west boundary on $\mathrm{H}$ Street } & (Q) \\
\hline SS-6 (CA) & \multicolumn{2}{|c|}{ SSFL Site, northeast corner of 4353} & (Q) \\
\hline SS-7 (CA) & \multicolumn{2}{|c|}{ SSFL Site, 4363 , north side } & (Q) \\
\hline SS-8 (CA) & \multicolumn{2}{|c|}{ SSFL Site, Former Sodium Disposal Facility north boundary } & (Q) \\
\hline SS-9 (CA) & \multicolumn{2}{|c|}{ SSFL Site, RMHF northeast boundary at 4133} & (Q) \\
\hline SS-11 (CA) & \multicolumn{2}{|c|}{ SSFL Site, 4036, east side } & (Q) \\
\hline SS-12 (CA) & \multicolumn{2}{|c|}{ SSFL Site, RMHF northwest property line boundary } & (Q) \\
\hline SS-13 (CA) & \multicolumn{2}{|c|}{ SSFL Site, RMHF northwest property line boundary } & (Q) \\
\hline SS-14 (CA) & \multicolumn{2}{|c|}{ SSFL Site, RMHF northwest property line boundary } & (Q) \\
\hline EMB-1 (CA) & SSFL Site, SRE ar & & (Q) \\
\hline EMB-2 (CA) & SSFL Site, south o & ention pond, off Test Area Road & (Q) \\
\hline & f-site Ambient Rac & ter Locations & \\
\hline OS-1 (CA) & Off-site, Chatswort & & (Q) \\
\hline OS-5 & Off-site, Thousand & & (Q) \\
\hline BKG-11 & Background Locat & & (Q) \\
\hline BKG-12 & Background Locat & & (Q) \\
\hline BKG-13 & Background Locati & & (Q) \\
\hline BKG-15 & Background Locat & (west) & (Q) \\
\hline BKG-18 & Background Locat & & (Q) \\
\hline BKG-19 & Background Locat & & (Q) \\
\hline BKG-22 & Background Locati & & (Q) \\
\hline Codes & & Locations & \\
\hline A & er Station & De Soto & \\
\hline W & ample & SSFL & \\
\hline $\mathrm{Q}$ & Sample & Off-site & \\
\hline $\mathrm{CA}$ & firmatory Location & Background & \\
\hline
\end{tabular}


Weekly ambient air samples are counted for gross alpha and beta radiation with a lowbackground thin-window gas-flow proportional-counting system. The system is capable of simultaneously counting both alpha and beta radiation. The sample-detector configuration provides a nearly hemispherical $(2 \pi)$ geometry. The thin-window detector is continually purged with argon/methane counting gas. A preset time mode of operation is used for counting all samples.

Counting system efficiencies are determined routinely with Tc-99 and Th-230 standard sources. The activities of the standard sources are traceable to the National Institute of Standards and Technology (NIST).

Filter samples for each ambient air sampling location are composited annually and analyzed for isotopic-specific activity. The results of the sample analyses are shown in Table 5-2 with the effluent results for comparison. As is the case with effluent air samples, the observed ambient air radionuclide concentrations were far below the ECL and DCG values. The variability in the measurements was dominated by weather effects and by analytical and background variations.

It should be emphasized that these measurements determine only the long-lived particulate radioactivity in the air and, therefore, do not show radon $(\mathrm{Rn}-222)$ and most of its daughter radionuclides. Polonium-210 is a long-lived daughter and is detected by these analyses. It is assumed to be in equilibrium with its parent, $\mathrm{Pb}-210$, whose relatively long half-life (22.3 years) provides an essentially constant level of Po-210 in the samples. Because of these effects, the ambient air, the air that is being breathed, is actually about four times as radioactive as implied in this table. Since most short-lived particulate radioactivity is removed from the exhaust air by the HEPA filters, these effects are not significant in the filtered effluent.

Because the alpha and beta activity are counted relatively soon after collection, most natural $\mathrm{Be}-7$ is detected, elevating the apparent beta activity. (Be-7 decays by electron-capture and emits a gamma ray in $10 \%$ of the decays. This gamma ray is weakly detected as beta activity.) The naturally occurring radionuclides, Po-210 and Ra-226 and Ra-228, also contribute to the activity detected on the stack exhaust filter samples. A more complete list of the results from the gross alpha and gross beta counting of the ambient air samples is shown in Table 5-5.

Guide values for SSFL site ambient air are based on the effluent concentration limits in 10 CFR 20 Appendix B (for licensed operations) and DOE Order 5400.5 for the DOE operations. The conservative guide value for alpha activity is $2 \times 10^{-14} \mu \mathrm{Ci} / \mathrm{mL}$. The appropriate value for beta activity is $9 \times 10^{-12} \mu \mathrm{Ci} / \mathrm{mL}$ (Sr-90) due to the presence of Sr-90 in fission product contamination from previous work with irradiated nuclear fuel at the SSFL. The appropriate guide value for De Soto ambient air activity is $2 \times 10^{-14} \mu \mathrm{Ci} / \mathrm{mL}(\mathrm{Pu}-239)$ for alpha and $6 \times 10^{-12}$ $\mu \mathrm{Ci} / \mathrm{mL}$ (Sr-90) based on isotopic analysis of samples during the 1998 remediation project.

The activity detected in ambient air is attributed to naturally occurring radioactive materials. Radionuclides detected by gross alpha and beta analysis of air samples collected during 1998 include K-40 plus several naturally occurring radionuclides from the uranium and thorium series (see Table 5-2). 
Table 5-5. Ambient Air Radioactivity Data-1998

\begin{tabular}{|c|c|c|c|c|c|}
\hline \multirow[b]{2}{*}{ Area } & \multirow[b]{2}{*}{ Activity } & \multirow[b]{2}{*}{$\begin{array}{l}\text { Number } \\
\text { of } \\
\text { Samples }\end{array}$} & \multicolumn{3}{|c|}{ Gross Radioactivity Concentrations $(\mu \mathrm{Ci} / \mathrm{mL})$} \\
\hline & & & $\begin{array}{c}\text { Annual Average } \\
\text { Value and } \\
\text { Dispersion }\end{array}$ & $\begin{array}{c}\text { Maximum Value } \\
\text { and Date } \\
\text { Observed }\end{array}$ & $\begin{array}{l}\text { Average } \\
\text { Percent of } \\
\text { Guide }^{b}\end{array}$ \\
\hline De Soto & Alpha & 51 & $(2.1 \pm 3.0) E-15$ & $9.0 E-15(9 / 16)$ & 10.5 \\
\hline Building 104 & Beta & & $(18.1 \pm 8.5) E-15$ & $64.9 E-15(8 / 26)$ & 0.3 \\
\hline SSFL Area IV & Alpha & 51 & $(2.5 \pm 3.1) E-15$ & $9.6 \mathrm{E}-15(8 / 19)$ & 12.5 \\
\hline Hot Lab & Beta & & $(19.0 \pm 8.7) E-15$ & $74.2 E-15(8 / 26)$ & 0.2 \\
\hline SSFL Area IV & Alpha & 51 & $(3.0 \pm 3.1) E-15$ & 11.1E-15 (7/15) & 15.0 \\
\hline RMHF & Beta & & $(19.1 \pm 8.7) \mathrm{E}-15$ & $72.1 E-15(8 / 26)$ & 0.2 \\
\hline SSFL Area IV & Alpha & 51 & $(2.3 \pm 3.0) \mathrm{E}-15$ & 10.1E-15 (8/26) & 11.5 \\
\hline 4886 & Beta & & $(13.8 \pm 7.4) E-15$ & 52.6E-15 (8/26) & 0.2 \\
\hline SSFL Area IV & Alpha & 51 & $(2.1 \pm 2.6) E-15$ & $8.5 E-15(10 / 2)$ & 10.5 \\
\hline RMHF Pond & Beta & & $(17.2 \pm 8.3) \mathrm{E}-15$ & $82.4 E-15(8 / 26)$ & 0.2 \\
\hline SSFL Area IV & Alpha & 4 & $(-3.3 \pm 3.3) E-15^{c}$ & $0.3 E-15(7 / 18)$ & -16.5 \\
\hline Hot Lab North & Beta & & $(123.0 \pm 32.8) \mathrm{E}-15$ & $150.0 \mathrm{E}-15(7 / 18)$ & 1.4 \\
\hline SSFL Area IV & Alpha & 3 & $(-2.0 \pm 0.8) E-15$ & $-1.5 E-15(7 / 18)$ & -10.0 \\
\hline Hot Lab South & Beta & & $(79.3 \pm 20.3) \mathrm{E}-15$ & $93.0 \mathrm{E}-15(7 / 18)$ & 0.9 \\
\hline SSFL Area IV & Alpha & 4 & $(-1.8 \pm 2.7) E-15$ & 1.1E-15 (6/26) & -9.0 \\
\hline Hot Lab East & Beta & & $(103.0 \pm 15.1) E-15$ & $120.0 E-15(6 / 26)$ & 1.1 \\
\hline SSFL Area IV & Alpha & 4 & $(-1.5 \pm 1.0) E-15$ & $-1.5 E-15(7 / 10)$ & -7.5 \\
\hline Hot Lab West & Beta & & $(117.0 \pm 38.5) E-15$ & $170.0 \mathrm{E}-15(11 / 4)$ & 1.3 \\
\hline \multicolumn{6}{|c|}{$\begin{array}{l}\text { aMaximum value observed for single sample. } \\
\text { "Guide De Soto Site: } 2 \mathrm{E}-14 \mu \mathrm{Ci} / \mathrm{mL} \text { alpha, } 6 \mathrm{E}-12 \mu \mathrm{Ci} / \mathrm{mL} \text { beta; CCR } 17 . \\
\text { SSFL site: } 2 \mathrm{E}-14 \mu \mathrm{Ci} / \mathrm{mL} \text { alpha, } 9 \mathrm{E}-12 \mu \mathrm{Ci} / \mathrm{mL} \text { beta, DOE Order } 5400.5(02 / 08 / 90) \text {. } \\
{ }^{c} \text { Values are background subtracted. Negative numbers indicate < background values }\end{array}$} \\
\hline
\end{tabular}

\subsubsection{Groundwater}

Forty-five wells in and around Area IV are used to monitor the condition of the groundwater in the unconsolidated surface alluvium and the underlying Chatsworth formation. The locations of these wells are shown in Figure 6-2. The purpose of these wells is to monitor concentrations of chemicals or radioactivity released by DOE operations. Water samples from these wells are periodically analyzed for radioactivity. The summary results for 1998 are shown in Table 5-6.

The regulatory limits for radioactivity in water from drinking water suppliers have been assigned to groundwater by the State of California as a water-quality goal, and are applied here. Numerical limits for radionuclides not specifically listed by the State for drinking water were derived from the EPA generic dose limit of 4 mrem/year by use of Dose Conversion Factors from RESRAD version 5.61. Except for six instances for gross alpha (15.2 to $45.8 \mathrm{pCi} / \mathrm{L}$ ), the 
monitored groundwater satisfies the goal. The gross alpha limit exceedences resulted from the presence of higher levels of naturally occurring uranium.

Table 5-6 Radioactivity in Groundwater at SSFL-1998

\begin{tabular}{|c|c|c|c|c|c|c|c|c|c|c|}
\hline & \multicolumn{10}{|c|}{ Activity (pCi/L) } \\
\hline & H-3 & Cs-137 & Th-228 & Th-230 & Th-232 & $U-234$ & U-235 & $\mathrm{U}-238$ & $\begin{array}{l}\text { Gross } \\
\text { Alpha }\end{array}$ & $\begin{array}{c}\text { Gross } \\
\text { Beta }\end{array}$ \\
\hline $\begin{array}{l}\text { Water } \\
\text { Suppliers } \\
\text { MCL }\end{array}$ & $20,000^{a}$ & 110 & 6.8 & 10 & 2.0 & \multicolumn{3}{|c|}{20 - Total Uranium } & $15^{\mathrm{a}}$ & $50^{a}$ \\
\hline Maximum & 2210 & ND & 0.04 & 0.138 & 0.025 & 14.2 & 7.9 & 13.3 & 45.8 & 18.6 \\
\hline Mean $^{b}$ & 113 & ND & 0.02 & 0.076 & 0.012 & 8.1 & 1.5 & 7.7 & 6.8 & 4.9 \\
\hline Minimum & -184 & ND & -0.01 & 0.039 & 0.00 & 0.5 & 0.02 & -0.01 & -1.7 & -19.0 \\
\hline $\begin{array}{l}\text { Number of } \\
\text { Analyses }^{c}\end{array}$ & $65(54)$ & $45(45)$ & $9(9)$ & $9(9)$ & $9(8)$ & $9(0)$ & $9(1)$ & $9(0)$ & $60(18)$ & $60(10)$ \\
\hline \multicolumn{11}{|c|}{$\begin{array}{l}{ }^{\mathrm{a}} \text { From } 40 \text { CFR } 141 \text { and EPA limit of } 4 \mathrm{mrem} / \mathrm{yr} \text { (see text). } \\
{ }^{\mathrm{b}} \text { The mean has been calculated from all reported values. ND = not detected }\end{array}$} \\
\hline
\end{tabular}

Groundwater is extracted from a French drain around a basement area of Building 4059 to prevent any inflow or outflow of groundwater into a part of the building currently undergoing remediation. During 1998, this water was released to the surface drainage water collection system. Samples were analyzed by gamma spectrometry. The results of these analyses showed no detectable activity for the remaining activation nuclides possible from 4059 . In no sample was any activity detected that indicated the possibility of contamination of this water.

Laboratory analyses were performed for tritium in water from 40 groundwater-monitoring wells and 4 off-site wells (see Figure 6-2). Of the 65 analyses performed, only 11 (all on-site wells) were above the method detection activity. The maximum result, $2,210 \mathrm{pCi} / \mathrm{L}$ in well $\mathrm{RD} 34 \mathrm{~A}$, is far below the EPA and California limits for drinking water suppliers of $20,000 \mathrm{pCi} / \mathrm{L}$. The maximum tritium levels were observed in Well RD-34A, with values of $2,210 \pm 180 \mathrm{pCi} / \mathrm{L}$. on $5 / 27 / 98$ and $2,060 \pm 180 \mathrm{pCi} / \mathrm{L}$ on $8 / 18 / 98$, and Well $\mathrm{RD}-54 \mathrm{~A}$, with a value of $497 \pm 170$ $\mathrm{pCi} / \mathrm{L}$ on $8 / 78 / 98$ and $354 \pm 130 \mathrm{pCi} / \mathrm{L}$ on $2 / 8 / 98$. Well RD-34A is located on recently acquired land near the RMHF in Area IV. Well RD-54A is located near the Former Sodium Disposal Facility 4886. RD-34B, adjacent to RD-34A showed $372 \pm 130 \mathrm{pCi} / \mathrm{L}(5 / 72 / 98)$ and $376 \pm 140$ $\mathrm{pCi} / \mathrm{L}(8 / 18 / 98)$. RD-24, near building 4059 , showed $358 \pm 130 \mathrm{pCi} / \mathrm{L}(2 / 18 / 98)$ and $299 \pm 140$ $\mathrm{pCi} / \mathrm{L}(8 / 4 / 98)$. RD-65 showed $322 \pm 130 \mathrm{pCi} / \mathrm{L}(2 / 7 / 98)$ and $\mathrm{RD}-28$ showed $267 \pm 130 \mathrm{pCi} / \mathrm{L}$ $(2 / 5 / 98)$.

One other well indicating detectable level of tritium was RD-23. The average detected tritium in the 11 wells was about $670 \mathrm{pCi} / \mathrm{L}$. Excluding the one well with the highest $\mathrm{H}-3$ content (RD-34A), the average was $340 \mathrm{pCi} / \mathrm{L}$. The history of tritium concentration in water from Well RD-34A is shown in Figure 5-3. Full scale on this plot is $20,000 \mathrm{pCi} / \mathrm{L}$, the allowable limit for suppliers of drinking water. Since the initial detection of about $7000 \mathrm{pCi} / \mathrm{L}$, the well has ranged between 1000 and $5000 \mathrm{pCi} / \mathrm{L}$. No off-site wells showed the presence of tritium. This 
occurrence of tritium in groundwater appears to have resulted from unintended production of tritium in soil surrounding the reactor test vessel in Building 4010 (shown in Figure 2-5).

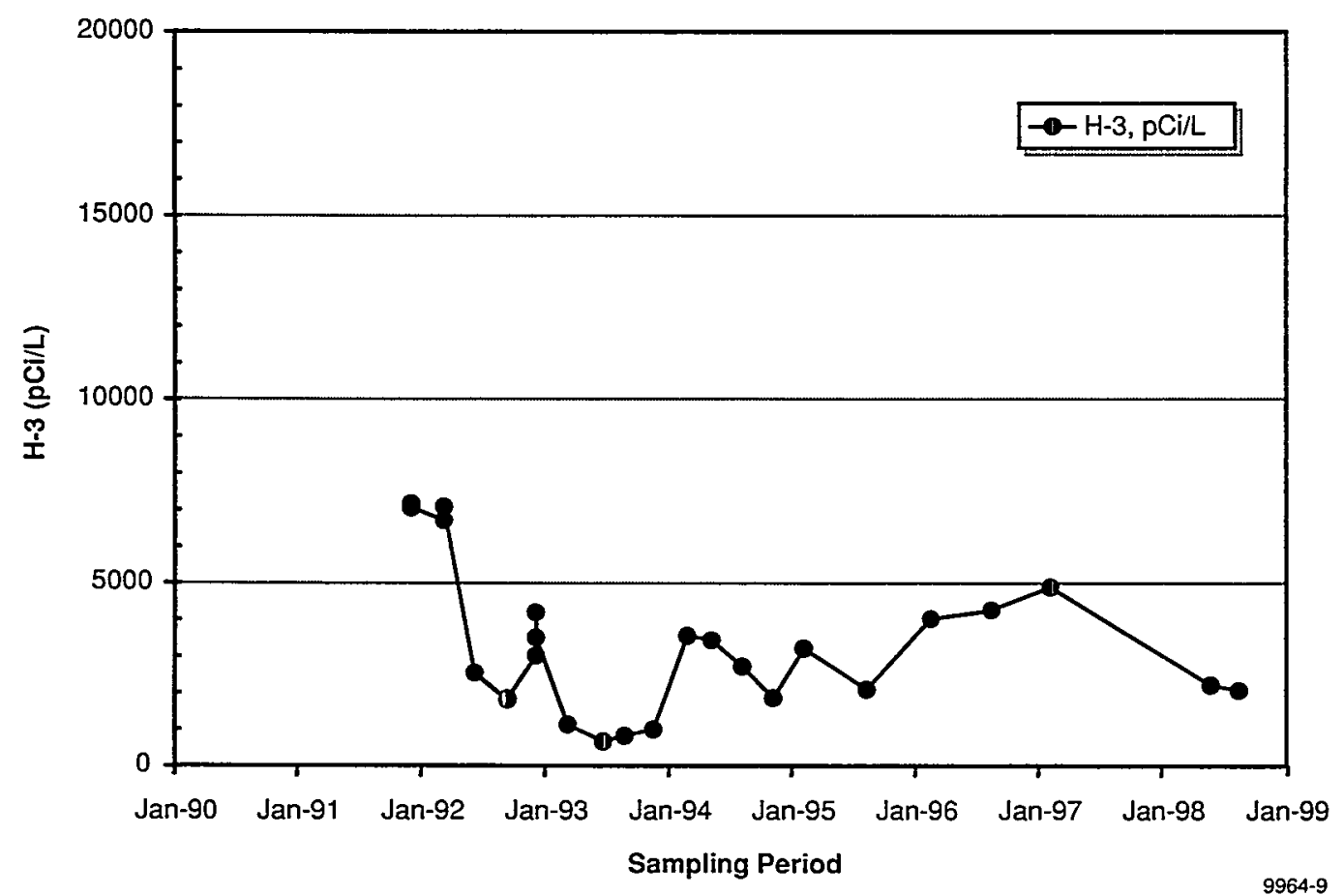

Figure 5-3. Tritium Concentration in Water from Well RD-34A

\subsubsection{Surface Water and Domestic Water Supply}

Most of Area IV slopes toward the southeast, and rainfall runoff is collected by a series of drainage channels and accumulates in the R2A Pond. Water from this pond is eventually released to Bell Creek under the NPDES permit. Water from the R2A Pond is also used for cooling the rocket engine test stand flame buckets where much of the cooling water evaporates. Some of Area IV slopes to the northwest, and a small amount of rainfall drains toward the northwest ravines, which lead into Meier Canyon. To permit sampling of this runoff, five catch basins were installed in 1989 near the site boundary to accumulate runoff.

Average radioactivity concentrations in these catch basin samples are summarized in Table 5-7. For radioactivity, the maximum contaminant limits (MCL) applicable to suppliers of drinking water (Title 22, Chapter 15, Article 5, Section 64443, of the California Code of Regulations) are imposed on releases from the two southern controlled discharge points (Outfalls 001 and 002) and the five northwest slope runoff channels (Outfalls 003 through 007). Although not required if gross alpha does not exceed $5 \mathrm{pCi} / \mathrm{L}$, the specific analyses for Ra-226 + Ra-228 were generally performed.

In none of the runoff events did any radiological analysis indicate an exceedance of these limits. Most results were below the detection capability of the analysis. 
Table 5-7. NPDES Discharge Radioactivity Data for Northwest Slope Monitoring-1998

\begin{tabular}{|c|c|c|c|c|c|c|}
\hline & \multicolumn{6}{|c|}{ Activity (pCi/L) } \\
\hline & $\mathrm{H}-3$ & Sr-90 & $\begin{array}{c}\text { Ra-226+ } \\
\text { R-228 }\end{array}$ & Gross Alpha & Gross Beta & Uranium \\
\hline $\begin{array}{l}\text { Water Suppliers } \\
\mathrm{MCL}\end{array}$ & 20,000 & 8 & 5 & 15 & 50 & 20 \\
\hline Maximum & 700 & 5.1 & 1.4 & 14.0 & 19.0 & NM \\
\hline Mean & 69 & 0.7 & 0.5 & 2.7 & 4.9 & $\mathrm{NM}$ \\
\hline Minimum & -20 & 0.0 & 0.0 & 0.0 & 0.1 & NM \\
\hline $\begin{array}{l}\text { Number of } \\
\text { Analyses }^{a}\end{array}$ & $47(42)$ & $47(39)$ & $47(46)$ & $47(27)$ & $47(5)$ & \\
\hline
\end{tabular}

Domestic water in this area is supplied by a variety of municipal and regional organizations, including the Los Angeles Department of Water and Power, several Ventura County Waterworks Districts, the Metropolitan Water District, the Burbank Public Service Department, and the Oxnard Public Works Department. Most of the water is imported from distant sources, such as Owens Valley, the Feather River, and the Colorado River. Some water, for Burbank, Oxnard, and Moorpark, comes from local groundwater wells. The local water is blended with imported water and treated to assure purity and safety. Water is transported in open aqueducts and enclosed pipelines and is stored in open reservoirs and underground settling basins. The State of California requires that these suppliers routinely monitor their water for many potentially hazardous materials (and less significant aesthetic quality factors, as well) and report the results of this monitoring to their customers on an annual basis. Tests for radioactivity are relatively limited, and are performed over an extended period of time, so not all parameters are reported in any one year. The results reported by local water suppliers during 1998 are shown in Table 5-8 and represent the averages of results of analysis of water supplied from the Burbank Public Service Department, the Metropolitan Water District (by far the largest supplier in the area), and the Ventura County Waterworks (District 1).

Comparison of the radioactivity concentrations in groundwater at SSFL from Table 5-7 with that of the local public supply water (Table 5-8) shows no significant differences in either the alpha or beta activity.

Table 5-8 Domestic Water Supplies Radioactivity Data

\begin{tabular}{|l|c|c|c|c|c|c|}
\cline { 2 - 7 } \multicolumn{1}{c|}{} & \multicolumn{7}{c|}{ Activity (pCi/L) } \\
\cline { 2 - 7 } \multicolumn{1}{c|}{} & H-3 & Sr-90 & $\begin{array}{c}\text { Ra-226+ } \\
\text { R-228 }\end{array}$ & Gross Alpha & Gross Beta & Uranium \\
\hline $\begin{array}{l}\text { Water Suppliers } \\
\text { MCL }\end{array}$ & 20,000 & 8 & 5 & 15 & 50 & 20 \\
\hline Maximum & ND & 2.3 & 2.9 & 14.8 & 17.8 & 6.0 \\
\hline Mean & ND & 1.1 & 1.3 & 5.6 & 1.9 & 3.6 \\
\hline Minimum & ND & 0.2 & 0.0 & 1.0 & $22(3)$ & $22(4)$ \\
\hline $\begin{array}{l}\text { Number of } \\
\text { reports }\end{array}$ & $19(19)$ & $20(13)$ & $23(7)$ & $24(5)$ & & 0.0 \\
\hline $\begin{array}{l}\text { a Numbers in parentheses represent the number of report entries listed as not detected. } \\
\text { ND = Not Detected }\end{array}$ \\
\hline
\end{tabular}




\subsubsection{Rock and Soil}

The radioactivity in native rock and soil can serve as an indicator of any spread of contamination outside the operating facilities and other known areas of radioactive contamination. Soil radioactivity is due to various naturally occurring radionuclides present in the environment and to radioactive fallout of dispersed nuclear weapons materials. Naturally occurring radionuclides include $\mathrm{K}-40$ and the uranium and thorium series (including radon and daughters). The radionuclide composition of local area surface soil has been determined to be predominantly $\mathrm{K}-40$, natural thorium, and natural uranium, both in secular equilibrium with daughter nuclides. Radioactivity in nuclear weapons test fallout consists primarily of the fissionproduced $\mathrm{Sr}-90$ and $\mathrm{Cs}-137$, as well as $\mathrm{Pu}-239$.

\subsubsection{4064 Side Yard and Adjacent Areas}

Soil sampling was conducted at the 4064 Side Yard area in 1998 as a part of the final survey and release process. In April 1998, 52 core soil samples were taken from 14 locations, spanning from surface to bedrock. The samples were analyzed with a multichannel analyzer (MCA) with a high purity germanium (HPGe) detector. All samples were well below the sitewide release criteria for soil.

In August 1998, 137 surface soil samples were taken as a part of the "Final Radiological Survey and Sampling Plan." The samples were screened with a 3-in-by-3-in sodium iodide ( $\mathrm{NaI}$ crystal attached to a portable MCA. Results indicated four samples had noticeable Cs-137 peaks. These samples were analyzed with the HPGe MCA system with results ranging from 2.6 to $6.3 \mathrm{pCi} / \mathrm{g} \mathrm{Cs}-137$. The gross $\mathrm{cpm}$ from the remaining samples statistically fell within the distribution range of background soil when plotted with CumPlot. The four elevated areas were remediated even though they were below release limits. The Cs-137 levels after excavation ranged from 0.43 to $1.3 \mathrm{pCi} / \mathrm{g}$.

A soil and asphalt sample at an elevated reading area, discovered during the walk-about portion of the final survey, revealed a Cs-137 concentration of $13.68 \mathrm{pCi} / \mathrm{g}$, which is higher than the site-wide release limit $(9.2 \mathrm{pCi} / \mathrm{g})$. To determine where the radiological contamination was located, the asphalt was separated from the soil by a sieve with 0.0331 -inch mesh. After analyzing the two separated samples, the Cs-137 contamination was found to be in both the soil $(7.4 \mathrm{pCi} / \mathrm{g})$ and in the asphalt (3.9 pCi/g). The asphalt and soil from this location were removed. Subsequent sampling of the location indicated only $0.5 \mathrm{pCi} / \mathrm{g} \mathrm{Cs}-137$ activity.

During the ORISE confirmatory survey, a small area to the southwest of the 4064 area was found to be contaminated ( $7 \mathrm{pCi} / \mathrm{g}$ to $5100 \mathrm{pCi} / \mathrm{g}$ ). The area was excavated and subsequent sampling showed a maximum of $3.1 \mathrm{pCi} / \mathrm{g}$, well below the release limit. The final survey and sampling of the 4064 Side Yard and adjacent areas is reported in Reference 4. 


\subsubsection{17th Street Drainage Area}

In 1997, seven soil locations were sampled and analyzed in-house for gamma spectroscopy during a subsequent radiation survey. Two of the samples contained Cs-137 levels above the release limit (14.9 and $13.5 \mathrm{pCi} / \mathrm{g}$ ). However, the 1998 characterization survey and soil sampling showed that all soil containing Cs-137 activity above the release limit was removed by the act of sampling in 1997. Three other samples contained slightly above background Cs-137 and above background Th-232 daughters (1.02 to 1.60$) \mathrm{pCi} / \mathrm{g}$. These five sampling locations were included in the excavation that took place in 1998.

In 1998, 18 locations were sampled and analyzed by gamma spectrometry and showed from 0.2 to $2.1 \mathrm{pCi} / \mathrm{g}$ of Cs-137. Twelve locations were analyzed by alpha spectrometry and showed from 0.95 to $6.2 \mathrm{pCi} / \mathrm{g}$ of Th-228. One location showed $0.14 \mathrm{pCi} / \mathrm{g} \mathrm{Pu}-239 / 240$, Although all these values were below the release limits, these locations were excavated.

Table 5-9 lists the excavation areas and compares the results of radiological activity before and after excavation. The highest post-excavation Cs-137 activity is $0.72 \mathrm{pCi} / \mathrm{g}$, or $8 \%$ of the cleanup standard of $9.20 \mathrm{pCi} / \mathrm{g}$. Since isotopic thorium is not analyzed for in post-excavation samples, the post excavation Th-228 is calculated by averaging the Th-232 daughters and then comparing this average to the pre-excavation ratio of Th-228 to average Th-232 daughters. The highest post-excavation Th-228 is estimated to be $1.4 \mathrm{pCi} / \mathrm{g}$, typical of background.

Table 5-9. $17^{\text {th }}$ Street Drainage Area Soil Summary

\begin{tabular}{|c|c|c|c|c|c|c|}
\hline \multirow[b]{2}{*}{$\begin{array}{c}\text { General } \\
\text { Locatio } \\
\mathbf{n}\end{array}$} & \multirow[b]{2}{*}{ Hotspot No. } & \multirow[b]{2}{*}{$\begin{array}{l}\text { Composite } \\
\text { Sample } \\
\text { Location }\end{array}$} & \multicolumn{2}{|c|}{ Pre-Excavation } & \multicolumn{2}{|c|}{ Post Excavation } \\
\hline & & & $\begin{array}{l}\text { Radioisotope } \\
\text { of Interest } \\
\text { (pCig) }\end{array}$ & Sample No. & $\begin{array}{l}\text { Radioisotope of } \\
\text { Interest (pCig) }\end{array}$ & Sample No. \\
\hline \multirow{11}{*}{$\begin{array}{l}\text { North } \\
\text { of } \\
\text { Berm }\end{array}$} & 9,10 & L19-66N-5E & - & - & Cs-137 $=0.39$ & ENV-98-263 \\
\hline & $17,22,27,28$ & L18-57N-195E & - & - & Cs-137 $=0.49$ & ENV-98-261 \\
\hline & $\begin{array}{c}18,19,23,24^{\mathrm{a}} \\
25,26,29,\end{array}$ & L18-65N-185E & Cs-137 =2.11 & $017-98-0002$ & Cs-137 $=0.53$ & ENV-98-262 \\
\hline & 20,21 & L18-66N-195E & $=$ & - & Cs-137 $=0.58$ & ENV-98-260 \\
\hline & 30 & L18-87N-190E & - & 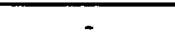 & Cs-137 $=0.72$ & ENV-98-264 \\
\hline & $31^{2}$ & L18-88N-178E & Cs-137 =0.95 & 017-98-0017 & Cs-137 $=0.07$ & ENV-98-265 \\
\hline & 32 & L18-95N-179E & - & - & Cs-137 $=0.34$ & ENV-98-266 \\
\hline & 11 & L19-77N-51E & - & - & Cs-137 $=0.39$ & ENV-98-259 \\
\hline & & & - & & & \\
\hline & 12 & L19-104N-106E & - & - & $\begin{array}{c}\text { Cs-137 }=0.28 \text { avg. of } \\
\text { Th-232 daughters } \cong 1.1\end{array}$ & ENV-98-268 \\
\hline & $13^{a}$ & L19-109N-105E & $\begin{array}{l}\text { Cs-137 }=1.07 \\
\text { Th-228 }=4.01\end{array}$ & $017-98-0018$ & $\begin{array}{c}\text { Cs-137 }=0.34 \text { avg. of } \\
\text { Th-232 daughters } \cong 1.0\end{array}$ & ENV-98-269 \\
\hline $\begin{array}{l}\text { South } \\
\text { of } \\
\text { Berm }\end{array}$ & $5,6,7^{a}, 8$ & L19-23N-62E & $\begin{array}{c}\text { Cs-137 = } 1.07 \\
\text { Th-228 = 6.24 } \\
\text { avg. of Th-232 } \\
\text { daughters } \equiv 5.0\end{array}$ & $\begin{array}{l}017-98-0005 \\
\text { ENV-98-250 }\end{array}$ & $\begin{array}{c}\text { Cs-137 }=0.06 \\
\text { Th-228 } \cong 1.4^{\mathrm{b}} \text { avg. of } \\
\text { Th-232 daughters } \cong 1.1\end{array}$ & ENV-98-267 \\
\hline $\begin{array}{l}{ }^{\mathrm{a}} \text { Hotspot } \\
{ }^{\mathrm{b}} \mathrm{Calculat} \\
\text { "_" = nos }\end{array}$ & $\begin{array}{l}\text { mpled } \\
\text { Th-228 concen } \\
\text { aple taken }\end{array}$ & tion (see text) & & & & \\
\hline
\end{tabular}


Several areas north of the berm were excavated as best management practice because they had Cs-137 and Th-228 levels higher than background levels but below release limits. One area south of the berm was excavated because it contained Th-228 close to the release limit. The total area excavated was approximately $1400 \mathrm{ft}^{2}$. The volume of soil removed was approximately $2100 \mathrm{ft}^{3}$ or $78 \mathrm{yd}^{3}$. Results from post-excavation sampling indicate the excavated areas are now at levels well below the radiological release limits. Representative samples from other hot-spot areas indicate only background or slightly above background levels of radiological activity. Therefore, the radiation remediation effort has been completed, and no further excavation is necessary. A final soil sampling and survey was performed in the spring of 1999.

\subsubsection{Hot Lab}

During the demolition of the Hot Lab Liquid Waste Tank Building (4468), 13 soil samples were taken for exploring the need to remediate contaminated soil and for pre-release of the facility. Only gamma spectrometry was performed on these samples, and so only the gamma emitting radionuclides are identified for these locations. The results of these analyses are shown in Table 5-10. The results indicate that all the samples are well below the site wide release limit for Cs-137 of $9.2 \mathrm{pCi} / \mathrm{g}$ as well as below normal fallout levels. Soil in the cavity left by the demolition was sampled by ORISE and the DHS/RHB before backfilling. Both agencies reported that all the samples were below the soil cleanup standards and typical of background. A final survey of the Hot Lab area is planned for the summer of 1999.

Table 5-10. Hot Laboratory Soil Radioactivity Data-1998

\begin{tabular}{|c|c|c|c|c|c|c|c|c|c|c|}
\hline \multicolumn{11}{|c|}{ Activity (pCi/g) ${ }^{a}$} \\
\hline & $\mathrm{Be}-7$ & $K-40$ & Cs-137 & Tl-208 & $\mathrm{Pb}-210$ & $\mathrm{~Pb}-212$ & $\mathrm{Bi}-212$ & $\mathrm{~Pb}-214$ & $\mathrm{Bi}-214$ & Ra-224 \\
\hline $\begin{array}{l}\text { Allowable } \\
\text { Soil Limit }\end{array}$ & natural & 27.6 & 9.2 & chain & chain & chain & chain & chain & chain & chain \\
\hline Maximum & 0.2 & 17.4 & 0.5 & 0.4 & 1.2 & 1.3 & 3.0 & 0.8 & 0.6 & 1.7 \\
\hline Mean & 0.1 & 15.1 & 0.1 & 0.3 & 0.8 & 1.1 & 0.6 & 0.6 & 0.6 & 1.3 \\
\hline Minimum & 0.1 & 12.3 & 0.02 & 0.3 & 0.6 & 0.8 & 0.1 & 0.6 & 0.5 & 1.1 \\
\hline $\begin{array}{l}\text { Number of } \\
\text { Analyses }\end{array}$ & $13(13)$ & $13(0)$ & $13(5)$ & $13(0)$ & $13(1)$ & $13(0)$ & $13(8)$ & $13(0)$ & $232(1)$ & $13(0)$ \\
\hline \multicolumn{11}{|c|}{ Activity (pCi/g) } \\
\hline & Ra-226 & $A c-228$ & Th-227 & Th-228 & Th-230 & Th-232 & Th-234 & U-234 & U-235 & U-238 \\
\hline $\begin{array}{l}\text { Allowable } \\
\text { Soil Limit }\end{array}$ & $\begin{array}{c}5 \text { and } \\
15\end{array}$ & chain & chain & chain & chain & $\begin{array}{c}5 \text { and } \\
15\end{array}$ & chain & 30.0 & 30.0 & 35.0 \\
\hline Maximum & 1.8 & 1.1 & 1.0 & 5.7 & 6.0 & 13.1 & 1.1 & 23.7 & 1.0 & 3.2 \\
\hline Mean & 1.3 & 0.9 & 0.2 & 4.8 & 5.3 & 11.6 & 0.7 & 20.3 & 0.2 & 2.6 \\
\hline Minimum & 0.4 & 0.8 & 0.1 & 4.2 & 4.6 & 10.2 & 0.5 & 17.8 & 0.1 & 1.8 \\
\hline $\begin{array}{l}\text { Number of } \\
\text { Analyses }\end{array}$ & $13(2)$ & $13(0)$ & $13(12)$ & $13(13)$ & $13(13)$ & $13(13)$ & $13(0)$ & $13(13)$ & $13(0)$ & $13(11)$ \\
\hline
\end{tabular}




\subsubsection{Vegetation}

Four vegetation samples were collected from the $17^{\text {th }}$ Street drainage area in 1998. No manmade radioactive isotopes were detected in any samples.

\subsubsection{Wildlife}

No animal samples were collected in 1998.

\subsubsection{Ambient Radiation}

During the later years of the nuclear programs at Atomics International and Rocketdyne, from 1974 through 1989, the ambient radiation monitoring program used rather complicated bulb-type dosimeters $\left(\mathrm{CaF}_{2}: \mathrm{Mn}\right)$. This was justified by the amount of nuclear materials handled in the operations at SSFL and De Soto, and by the low levels of radiation in the environment. At the termination of all nuclear work in 1989, such a program was no longer needed, and efforts were directed toward simplifying the program. This was done initially by using the same dosimeters $(\mathrm{LiF})$ that were well established in use for personnel monitoring in radiation work. While these dosimeters are well suited to measuring exposures in the range of interest for compliance with occupational radiation regulations (doses "above background"), they are somewhat insensitive for environmental measurements since the resolution in terms of dose uses increments of 10 mrem per quarter. Using these dosimeters demonstrated that environmental exposures did not reach regulatory limits, but provided limited information on the actual exposure rates present around the facilities and in the neighboring environment.

In addition to the LiF TLDs discussed above, Rocketdyne began deploying, in the last quarter of 1995, environmental TLDs that use an aluminum oxide ("sapphire") chip. These TLDs are capable of determining doses in increments of $0.1 \mathrm{mrem}$ (compared to $10 \mathrm{mrem}$ for the LiF-based badges previously used). In addition, the aluminum oxide badge reporting is much more detailed, providing both gross and corrected readings for the locations. Proper use of the control badges supplied with these dosimeters allows elimination of the natural and transportation exposure that occurs before, during, and after the deployment of the environmental dosimeters to measure the ambient radiation. This permits accurate determination of the net exposure received while the environmental TLDs are in the field, exposed to the ambient radiation. In various intercomparisons, aluminum-oxide-based dosimeters have been shown to be among the most accurate dosimeters available in measuring environmental exposure rates.

The State DHS/RHB provides packages containing calcium sulfate $\left(\mathrm{CaSO}_{4}\right)$ dosimeters for independent monitoring of radiation levels at SSFL and in the surrounding area. These dosimeters are placed at specific locations along with the Rocketdyne TLDs. The State dosimeters are returned to the Radiologic Health Branch for evaluation. Data for these TLDs, which were placed at various Rocketdyne dosimeter locations both on-site and off-site, are also shown in Table 5-11 for 1998. 
Except for dosimeter locations SS-12, and -13, Table 5-11 shows that radiation exposures and equivalent annual exposure rates monitored on-site are nearly identical to levels monitored at the offsite locations. These data reflect the natural variability of background radiation from cosmic radiation, radionuclides in the soil, and radon and thoron in the atmosphere. Radiation doses measured at locations SS-12, and -13 , are slightly higher, and are reflective of normal operations at the RMHF, which involve handling and shipment of radioactive material. Note, however, that SS-12 and -13 measure the dose at the old Rocketdyne boundary. In February 1998, there was a change to Rocketdyne's northern boundary. Because of the new boundary's further distance from the RMHF and the shielding effects of the large rock cliffs between the RMHF and the new boundary, the dose rates there would be indistinguishable from natural background.

The natural background radiation level as measured by the off-site ranges from 63 to 111 $\mathrm{mrem} / \mathrm{yr}$. At the SSFL the local background ranges from 83 to $112 \mathrm{mrem} / \mathrm{yr}$, based on the data from dosimeters SS-3, -4, -6, -7, -8, -11, -14 and EMB-1 and EMB-2 as shown in Table 5-11. At De Soto, the local background ranges from 79 to $104 \mathrm{mrem} / \mathrm{yr}$. The small variability observed in these values is attributed to differences in elevation and geologic conditions at the various sites. The altitude range for the dosimeter locations is from approximately $260 \mathrm{~m}(850 \mathrm{ft})$ ASL at the De Soto facility and the off-site locations to a maximum of approximately $580 \mathrm{~m}(1,900 \mathrm{ft}) \mathrm{ASL}$ at SSFL.

Analysis of the results demonstrates that compliance was achieved with the annual limits of the NRC, the State of California Department of Health Services, and the U.S. Department of Energy the limit being $100 \mathrm{mrem} / \mathrm{yr}$ for total dose, above natural background, to the maximally exposed individual.

\subsection{ESTIMATION OF PUBLIC RADIATION DOSE}

\subsubsection{Individual Dose}

The effective dose equivalent for any member of the public, for all pathways (combining internal and external dose), shall not exceed $100 \mathrm{mrem} / \mathrm{yr}$ (above background) for DOE facilities or State of California licensed facilities. The estimated off-site doses are indistiguishable from background. The old boundary to the north of the RMHF facility received an estimated average "old property line" exposure of approximately $46 \mathrm{mrem} / \mathrm{yr}$ above the local background. However, the extended boundary to the North of the RMHF and the high rocky terrain between the new boundary and the RMHF acts as an effective shield and makes the exposure from direct radiation at the new boundary indistinguishable from background. Exposure from direct radiation at the nearest residence would also be indistinguishable from background for the same reason. 
Table 5-11. De Soto and SSFL Ambient Radiation Dosimetry Data-1998

\begin{tabular}{|c|c|c|c|c|c|c|c|c|}
\hline \multirow{2}{*}{\multicolumn{2}{|c|}{\begin{tabular}{|c|}
1998 \\
TLD-Locations \\
\end{tabular}}} & \multicolumn{4}{|c|}{$\begin{array}{l}\text { RD Quarterly Exposure } \\
\text { (mrem) }\end{array}$} & \multirow{3}{*}{$\begin{array}{c}\begin{array}{c}\text { Annual } \\
\text { Exposure } \\
\text { (mrem) }\end{array} \\
79.1\end{array}$} & \multicolumn{2}{|c|}{$\begin{array}{c}\text { Annual Average } \\
\text { Exposure } \\
\text { Rate }(\mu \mathrm{R} / \mathrm{h})\end{array}$} \\
\hline & & \multirow{2}{*}{$\begin{array}{r}\text { Q-1 } \\
23.1\end{array}$} & \multirow{2}{*}{$\begin{array}{c}\text { Q-2 } \\
18.4\end{array}$} & \multirow{2}{*}{$\frac{Q-3}{19.8^{*}}$} & \multirow{2}{*}{$\begin{array}{c}\mathrm{Q}-4 \\
17.8\end{array}$} & & \multirow{2}{*}{$\frac{\text { Rocketdyne }}{9.0}$} & \multirow{2}{*}{$\frac{\text { State DHS }}{--}$} \\
\hline De Soto & DS-2 & & & & & & & \\
\hline & DS-6 & 25.4 & 21.1 & 24.4 & 21.0 & 91.9 & 10.5 & -- \\
\hline & DS-8 & 24.9 & 20.9 & 24.8 & 22.0 & 92.6 & 10.6 & -- \\
\hline & DS-9 & 29.8 & 25.4 & 22.6 & 26.6 & 104.4 & 11.9 & -- \\
\hline \multicolumn{2}{|c|}{ Mean Values } & 25.8 & 21.5 & 22.9 & 21.9 & 92.0 & 10.5 & \\
\hline \multirow[t]{12}{*}{ SSFL } & SS-3 & 28.6 & 21.4 & 26.9 & 26.1 & 103.0 & 11.8 & 10.4 \\
\hline & SS-4 & 25.9 & 22.4 & 26.5 & 27.7 & 102.5 & 12.7 & 11.6 \\
\hline & SS-6 & $20.7^{*}$ & 20.4 & 20.2 & 21.4 & 82.7 & 9.4 & 11.6 \\
\hline & SS-7 & 26.2 & 21.4 & 23.0 & $23.5^{\star}$ & 94.1 & 10.7 & 11.2 \\
\hline & SS-8 & 31.3 & $27.9^{\star}$ & 28.3 & 24.2 & 111.7 & 12.8 & 11.5 \\
\hline & SS-9 & 25.0 & 23.3 & 27.2 & 24.7 & 100.2 & 11.4 & 12.4 \\
\hline & SS-11 & 30.7 & 24.4 & 24.1 & 23.7 & 102.9 & 11.7 & 11.7 \\
\hline & SS-12 & 32.3 & 31.6 & 26.2 & 31.9 & 122.0 & 13.9 & 15.0 \\
\hline & SS-13 & 32.1 & 32.8 & 31.5 & 39.0 & 135.4 & 15.5 & 14.6 \\
\hline & SS-14 & 30.5 & 22.6 & $25.5^{\star}$ & 26.0 & 104.6 & 11.9 & 12.3 \\
\hline & EMB-1 & 17.1 & 24.7 & 24.4 & 22.1 & 88.3 & 10.1 & 12.3 \\
\hline & EMB-2 & 24.3 & 21.8 & 25.4 & 25.8 & 97.3 & 11.1 & 12.0 \\
\hline \multicolumn{2}{|c|}{ Mean Values } & 27.1 & 24.6 & 25.8 & 26.3 & 103.7 & 11.8 & 12.2 \\
\hline \multirow[t]{9}{*}{ Off-site } & OS-1 & 23.0 & $22.3^{*}$ & 19.6 & 21.1 & 85.9 & 9.8 & 9.7 \\
\hline & OS-5 & 21.2 & $19.9^{\star}$ & $19.9^{\star}$ & 18.7 & 79.7 & 9.1 & -- \\
\hline & BKG-11 & 15.8 & 16.4 & 15.5 & 15.7 & 63.4 & 7.2 & -- \\
\hline & BKG-12 & 22.3 & 19.4 & 16.6 & 17.8 & 76.1 & 8.7 & -- \\
\hline & BKG-13 & 20.1 & 15.8 & 13.4 & $16.4^{*}$ & 65.7 & 7.5 & -- \\
\hline & BKG-15 & 19.6 & $17.4^{*}$ & 15.1 & $17.4^{\star}$ & 69.4 & 7.9 & -- \\
\hline & BKG-18 & 19.5 & 21.6 & 19.3 & 20.7 & 81.1 & 9.3 & -- \\
\hline & BKG-19 & 21.5 & 21.7 & 18.1 & 22.6 & 83.9 & 9.6 & -- \\
\hline & BKG-22 & 18.3 & 28.1 & 34.1 & 30.3 & 110.8 & 12.6 & -- \\
\hline \multicolumn{2}{|c|}{ Mean Values } & 20.1 & 20.3 & 19.1 & 20.1 & 79.6 & 9.1 & - \\
\hline
\end{tabular}


Estimates of the internal dose from airborne releases assume a constant unsheltered exposure throughout the year, adjusted for wind direction frequency, and therefore considerably overestimate the actual annual averaged doses near the site. Estimated internal radiation doses due to atmospheric emission of radioactive materials from SSFL nuclear facilities are calculated by use of the EPA program CAP88-PC, and are many orders of magnitude below the radiation standards and are far below doses from internal exposure resulting from natural radioactivity in air. For the air pathway only, for DOE operations, the standard is $10 \mathrm{mrem} / \mathrm{yr}$ for committed effective dose equivalent, as established by EPA.

Internal dose from the De Soto site was $0 \mathrm{mrem} / \mathrm{yr}$ because no effluents were emitted during the final remediation in Building 104.

Public exposure to radiation and radioactivity is shown in Tables 5-12 and 5-13. These tables present the estimated exposures in comparison to the regulatory standards. Dose values in the tables represent both internal and external exposures.

\section{Table 5-12. Public Exposure to Radiation and Radioactivity from DOE Operations at SSFL-1998}

\section{Radioactive Materials Handling Facility (RMHF) and 4024 Hot Lab Satellite Department of Energy (DOE, Exempt from Licensing)}

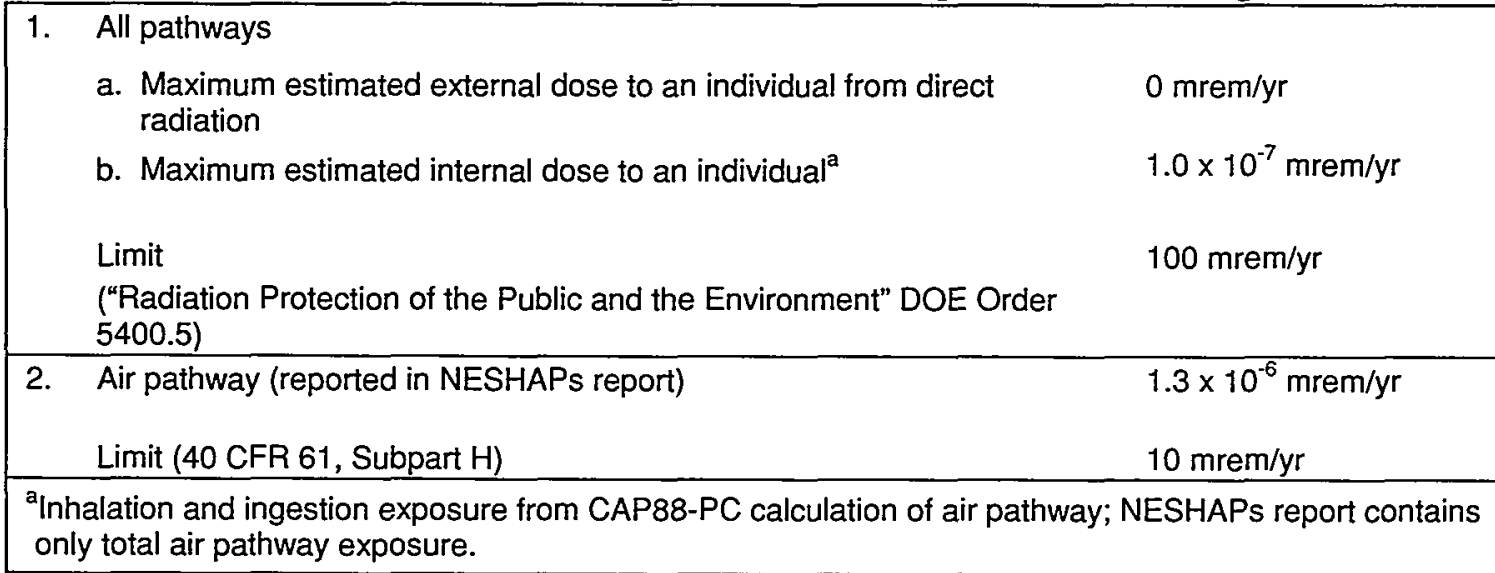

Table 5-13. Public Exposure to Radiation and Radioactivity
from Licensed Operations at De Soto-1998

Applied Nuclear Technology Laboratory (DS104)

State of California Radioactive Materials License No. 0015-70

\begin{tabular}{|c|c|c|}
\hline & $\begin{array}{l}\text { Direct radiation at boundary } \\
\text { Limits (CCR } 17 \text { Section } 30253 \text { ) }\end{array}$ & $\begin{array}{l}0 \mathrm{mrem} / \mathrm{yr} \\
100 \mathrm{mrem} \text { in } 1 \mathrm{yr}\end{array}$ \\
\hline \multirow[t]{2}{*}{2.} & Airborne (non-natural radioactivity) effluent at boundary ${ }^{\mathrm{a}}$ & $0 \mu \mathrm{Ci} / \mathrm{mL}$ \\
\hline & Limit (CCR 17 Section 30253) & $2 \mathrm{E}-14 \mu \mathrm{Ci} / \mathrm{mL}$ \\
\hline
\end{tabular}




\subsubsection{Population Dose}

The general population (person-rem) dose estimates were calculated using CAP88-PC code. This code uses release rate, wind speed, wind direction and frequency, stability fractions, and stack height parameters as input data. Population dose estimates are $9.4 \times 10^{-2}$ person-rem for the SSFL site ( $3.2 \times 10^{-4}$ person-rem from the RMHF stack) and 0 person-rem for the De Soto site. The collective effective dose equivalent estimated for potential area sources in 1998 is $9.4 \mathrm{x}$ $10^{-2}$ person-rem, included in the SSFL total. Reducing the $17^{\text {th }}$ Street Drainage Area thorium to natural levels and totally eliminating the thorium yields $2.9 \times 10^{-2}$ person-rem $\left(2.9 \times 10^{-6}\right.$ person$\mathrm{Sv}$ ), and $3.0 \times 10^{-3}$ person-rem ( $3.0 \times 10^{-7}$ person-rem) respectively, again demonstrating the impact of even the smallest quantity of thorium. Inhalation is the only potential exposure pathway likely to exist. Figure 5-4 shows the arrangement of the census tract boundaries from the 1990 census. Figures 5-5 through 5-7 show local population distribution estimates that were determined from the 1990 Federal census by Urban Decision Systems, Inc., and modified by direct observation of nearby residential areas around the SSFL site, and the occupational population at SSFL.

In spite of the large number of people in the surrounding population, the population dose estimated for Rocketdyne operations is extremely small. For comparison, the dose received by the same population from naturally occurring radiation is approximately 3 million person-rem, approximately 100 million times greater than that estimated for SSFL operations.

To account for population increases, analytical results using the 1990 census data were multiplied by 1.10 for Area IV of the SSFL. This factor was based on estimated population increases in Los Angeles and Ventura counties since 1990 as reported by the US Census Bureau. 


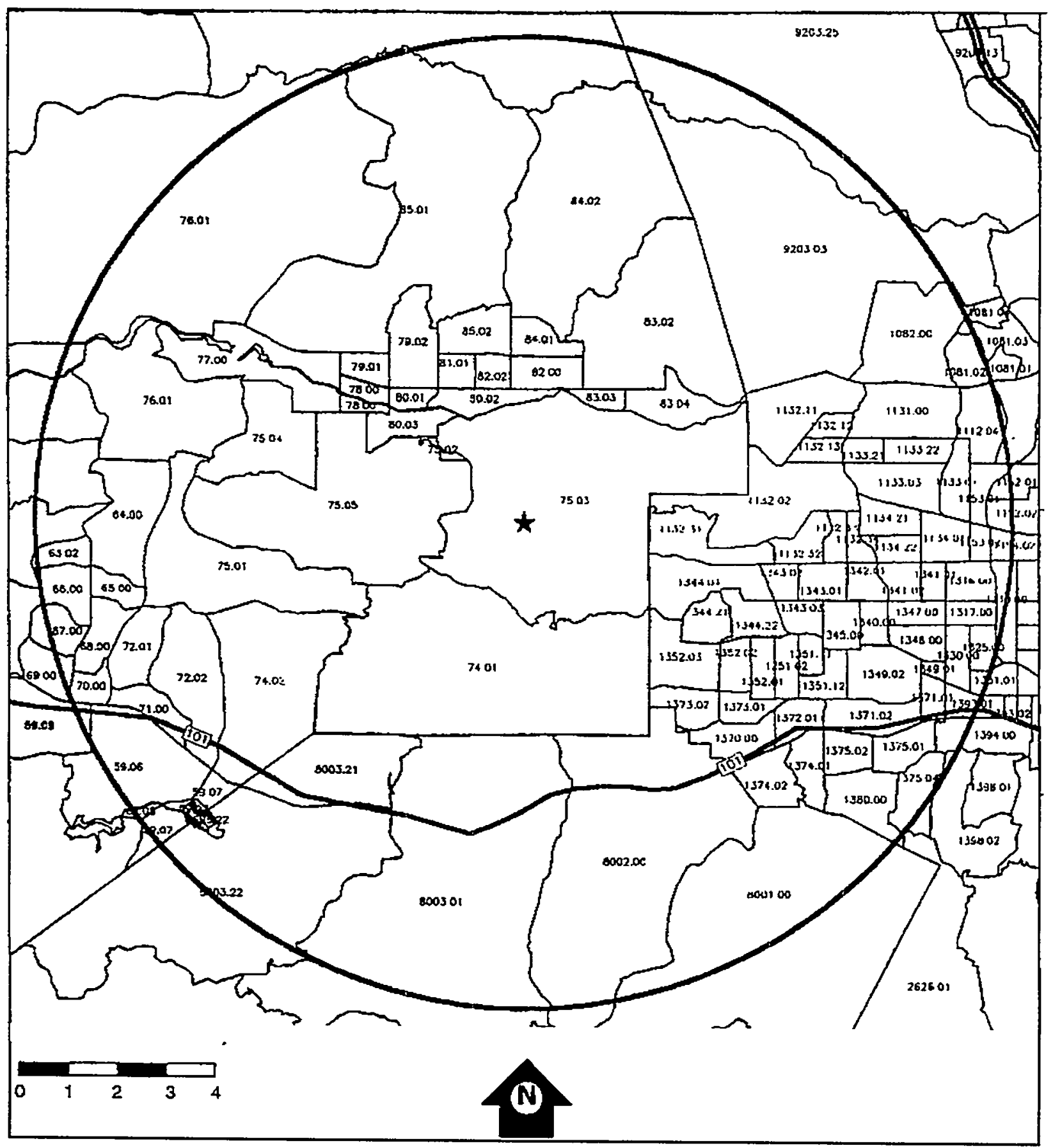

Figure 5-4. Census Tract Boundaries (1990) within 10 miles of SSFL (individual tracts are identified by number) 


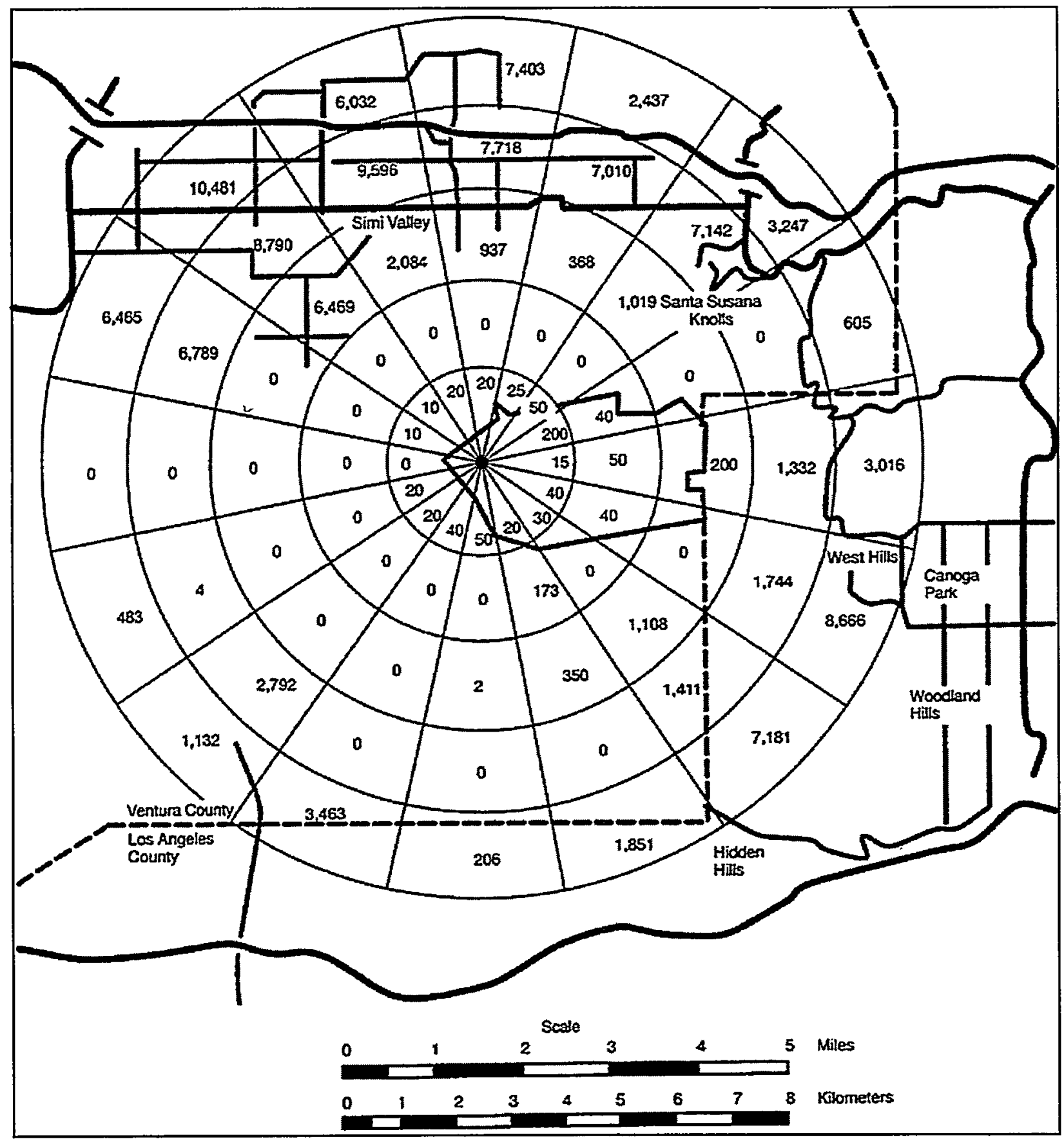

$9964-11$

Figure 5-5. SSFL Site-Centered Demography to 8 km (1990), Showing Number of Persons Living in Each Grid (daytime employment for SSFL) 


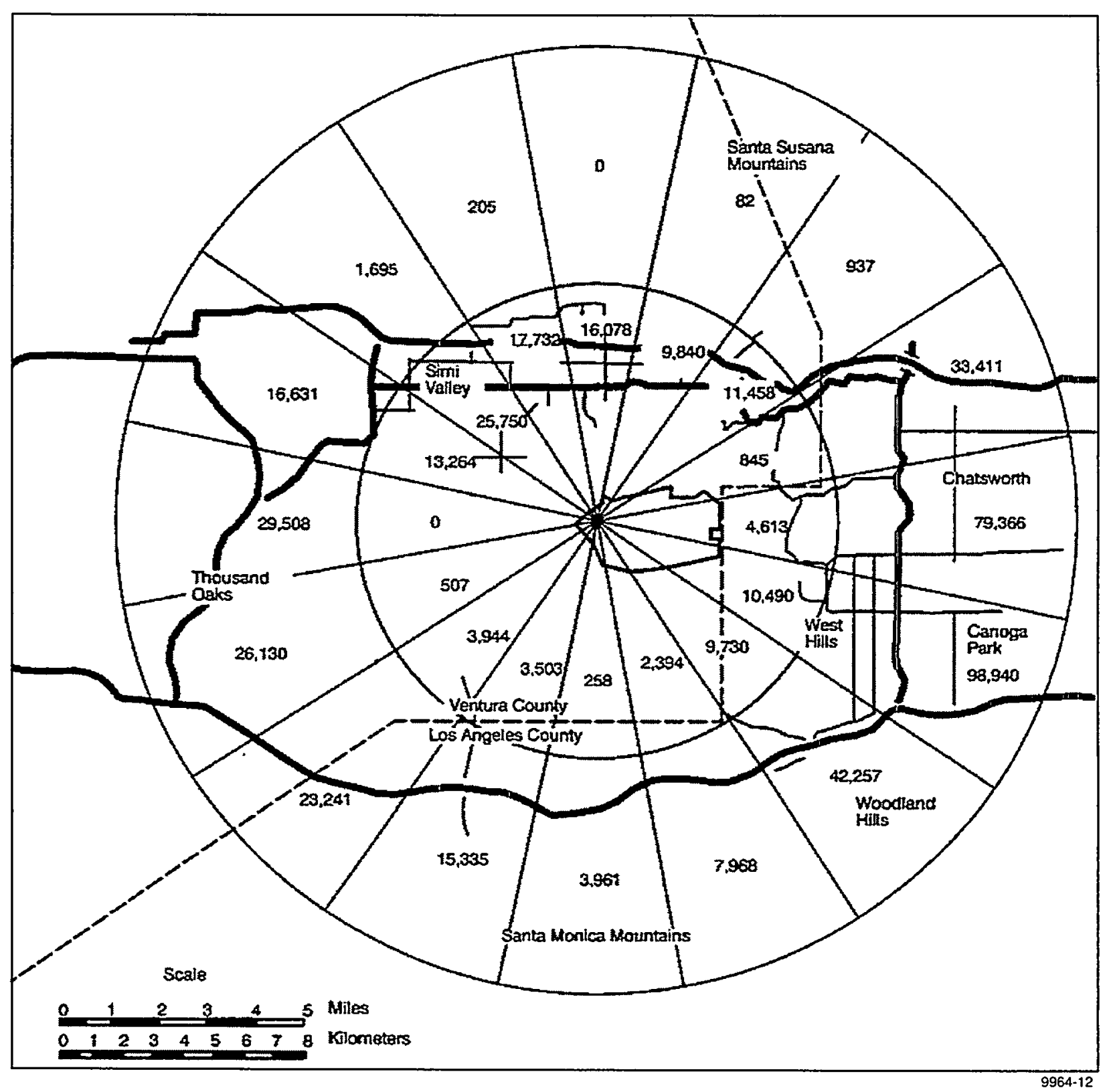

Figure 5-6. SSFL Site-Centered Demography to $16 \mathrm{~km}$ (1990), Showing Number of Persons Living in Each Grid 


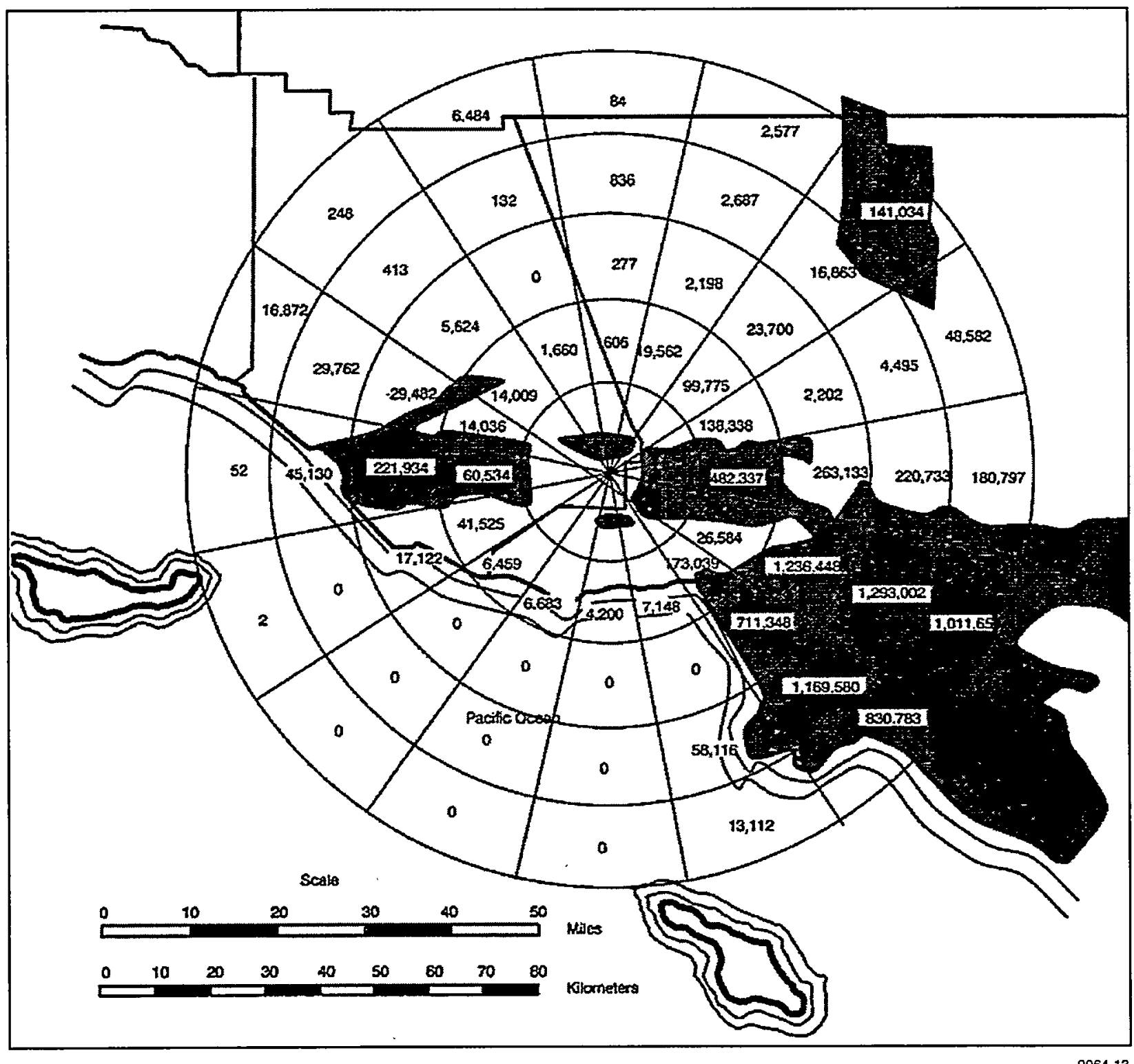

Figure 5-7. SSFL Site-Centered Demography to $80 \mathrm{~km}$ (1990), Showing Number of Persons Living in Each Grid (heavily populated areas are shown by shading) 
RD99-115

This page intentionally left blank. 


\section{ENVIRONMENTAL NON-RADIOLOGICAL MONITORING}

Rocketdyne maintains a comprehensive environmental program to ensure compliance with all applicable regulations, to prevent adverse environmental impact, and to restore the quality of the environment from past operations.

An extensive site-wide (SSFL) groundwater remediation program has the capacity for removing solvent contamination from approximately 10 million gallons of groundwater per month at SSFL. The major groundwater contaminant in Area IV is TCE and its degradation products. Three interim groundwater extraction system wells have been installed in Area IV and evaluation of their performance is in progress.

The discharge of surface water at SSFL results from collection of rainfall runoff or is due to the nonutilization of treated groundwater and is regulated by the California Regional Water Quality Control Board through an NPDES permit. The majority of surface water runoff drains to the south and is collected in the water reclamation/pond system. Discharges from this system are subject to effluent limitations and monitoring requirements as specified in the existing NPDES permit. A small portion of the site within Area IV generates rainfall runoff to five northwest boundary runoff channels where monitoring locations (Figure 6-1) have been established and sampling is conducted in accordance with the northwest slope monitoring program. All discharges are periodically monitored for volatile organics, heavy metals, and applicable radionuclides, in addition to other parameters necessary to assess water quality.

All sources of air emissions at SSFL are subject to the provisions of the Clean Air Act as administered through the California Air Resources Board and the Ventura County Air Pollution Control District. The VCAPCD regulates sources of air emissions and issues permits that contain limits on pollutant levels and conditions of operation.

The overall annual groundwater monitoring program at SSFL addresses collection and analysis of groundwater samples and measurement of the water levels for the 227 Rocketdyne installed wells on-site and off-site and 16 off-site private wells. The locations of these wells within and around DOE areas in Area IV are shown on the map of SSFL in Figure 6-2. Groundwater quality parameters and sampling frequency have been determined based on historical water quality data, location of known or potential sources of groundwater contamination, operational requirements of groundwater extraction and treatment systems and regulatory direction. The groundwater monitoring program includes the following parameters, all analyzed using the appropriate EPA methods: volatile organic constituents, base/neutral and acid extractable organic compounds, petroleum hydrocarbons, and trace metals and common ion constituents. Radiological analyses are performed on groundwater samples from DOE areas in Area IV and off-site.

Petroleum hydrocarbon contaminated soils resulting from underground storage tanks (UST) have been remediated as tanks are removed. The majority of the storage tanks have been removed. The few remaining USTs contain either sodium or radioactive water and are located within concrete vaults and equipped with automatic leak detection systems. As stated previously, these tanks are exempt from the UST regulations. 


\subsection{SURFACE WATER}

Rocketdyne has filed a Report of Waste Discharge with the California Regional Water Quality Control Board and has been granted a discharge permit pursuant to the National Pollutant Discharge Elimination System and Section 402 of the federal Water Pollution Control Act. The permit to discharge, NPDES No. CA0001309, initially became effective September 27, 1976 , and was most recently renewed on June 29, 1998. The current permit is in effect through May 10, 2003.

The permit allows the discharge of reclaimed wastewater and storm water runoff from water retention ponds into Bell Creek, a tributary to the Los Angeles River, in addition to the discharge of storm water runoff from the northwest slope (Area IV) locations. Discharge along the northwest slope (RMHF: Outfall 003, SRE: Outfall 004, OSDF West: Outfall 005, OSDF East: Outfall 006, and T100: Outfall 007) generally occurs only during and after periods of heavy rainfall. The permit applies the numerical limits for radioactivity in drinking water supplies to drainage through these outfalls. Excess reclaimed water is discharged on a continuous basis from the R-2A Pond that ultimately releases through Outfall 002.

There is no sanitary sewer connection to a publicly owned treatment works from SSFL. Domestic sewage is treated, disinfected, and discharged to the retention ponds. Permit conditions are placed on the operation of the two treatment plants. Area IV sewage is piped directly to the Area III Sewage Treatment Plant (STP III).

Of the two retention ponds at SSFL that discharge via the NPDES permit, only one receives influent from Area $I V$, and is referred to as R-2A Pond. Influent to the ponds includes tertiary treated domestic sewage, cooling water from various testing operations, treated ground water and storm water runoff. During periods of discharge from the ponds, grab samples are collected and sent to a California State certified testing laboratory for analysis. Analyses include chemical constituents such as heavy metals, volatile organics, base/neutral and acid extractable, and general chemistry in addition to specified radionuclides. Toxicity testing is also conducted in the form of acute and chronic toxicity bioassays.

In November 1989, a storm water runoff program was developed and implemented in Area IV for runoff from the northwest portion of the site. Five monitoring locations were selected that include the Radioactive Materials Handling Facility watershed (Outfall 003), Sodium Reactor Experiment watershed (Outfall 004), the Former Sodium Disposal Facility (Outfalls 005 and 006), and behind 4100 (Outfall 007). Runoff monitoring is currently conducted as set forth by the NPDES permit referenced above. Furthermore, all surface water program activities for the SSFL, including Area IV, have been addressed and incorporated into the current NPDES permit. The Storm Water Pollution Prevention Plan and the NPDES permit were both prepared in accordance with the current federal and state regulations. 
RD99-115

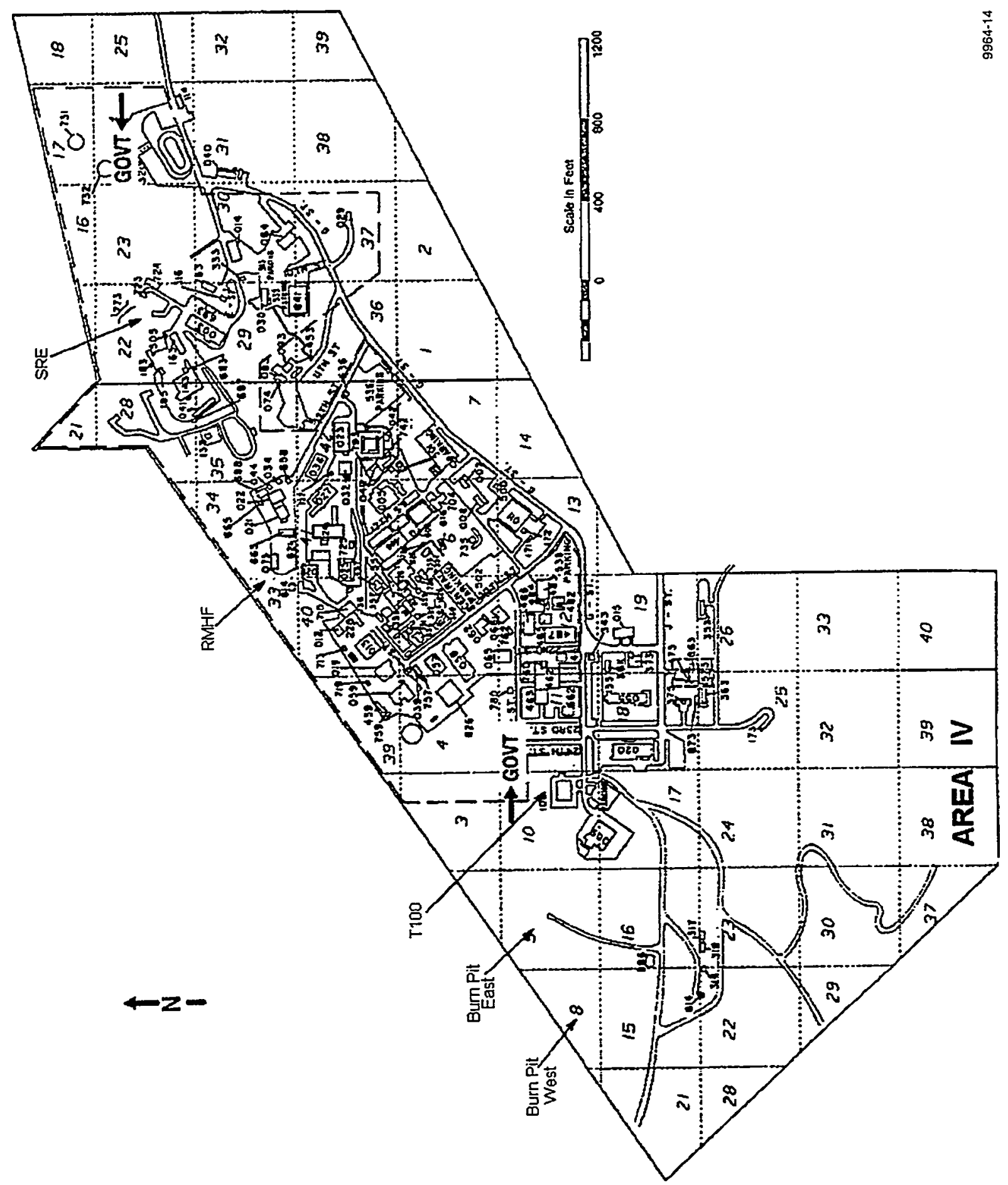

Figure 6-1. Locations of Surface Water Runoff Collectors Along Northwest Boundary of SSFL, Area IV 


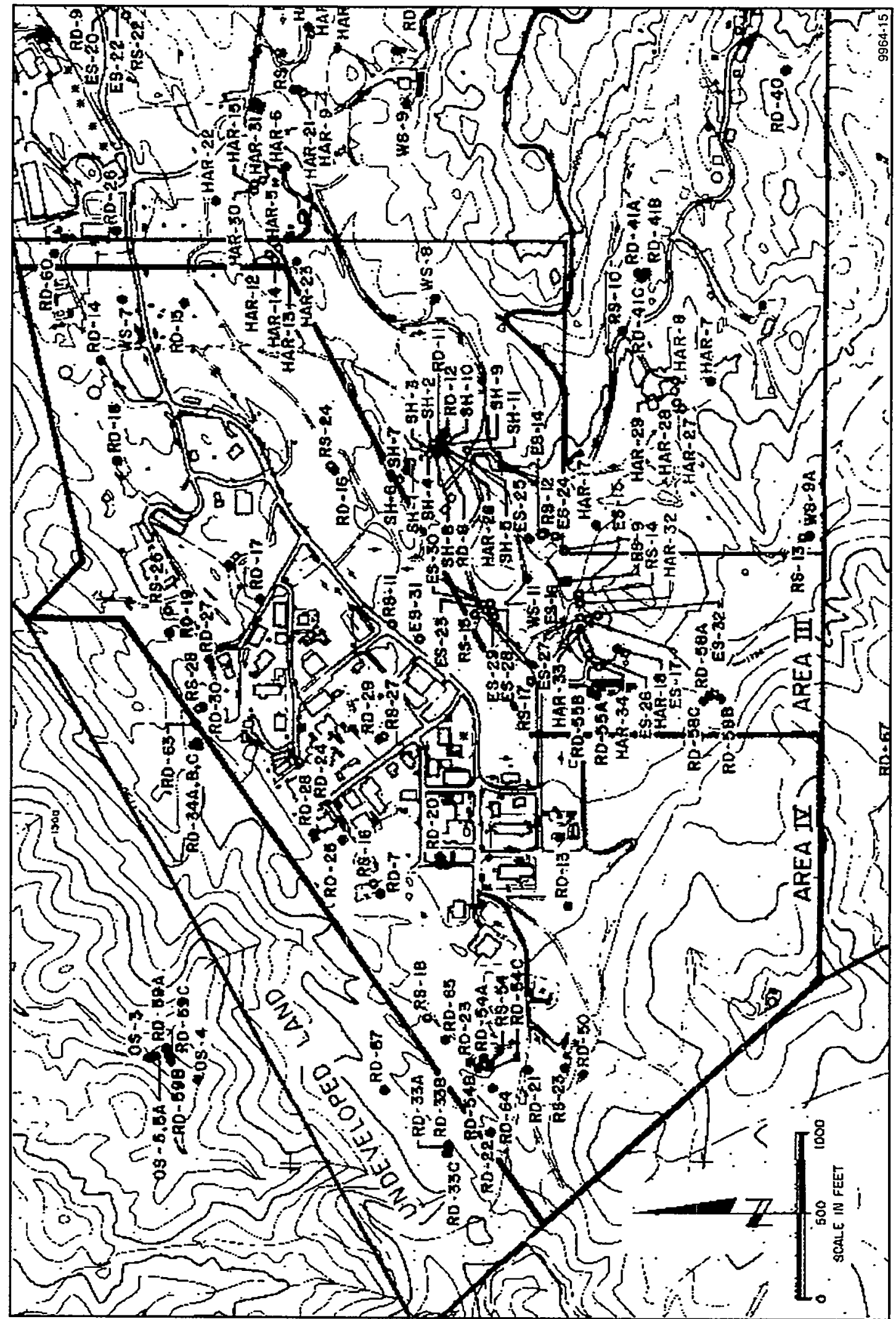

Figure 6-2. Location of Wells Used in Groundwater Management Program 
The permit imposes the contaminant limits for drinking water suppliers, relative to radioactivity, and goes beyond the requirements of the drinking water supplier regulations in requiring more frequent sampling and analysis. During wet weather flow (rainfall is greater than $0.1 \mathrm{inch}$ ) no more than one sample per 2 weeks needs to be obtained from each of the seven outfalls. During dry weather flow, whenever there is discharge, minimum sampling frequency for Outfalls 001 and 002 is once per month.

\subsection{AIR}

Atmospheric pollutant discharge limitations are imposed by VCAPCD Permit 0271. The air permit is kept current and is issued each year by the Ventura County Air Pollution Control District (VCAPCD).

At present, the sodium treatment facility (Bldg 4133) and the ethanol cleaning operation at SPTF (Bldg 4463) are the only permitted areas, however, Building 4133 has been in closure since June 1998.

Although ETEC has traditionally had little or no ODS's, Rocketdyne has for years maintained a Hazardous Materials Elimination Team to eliminate ODS's at Rocketdyne. This multifunctional team has the responsibility to identify suitable alternatives for various toxic chemicals and has been instrumental in eliminating CFC-113 and 1,1,1-trichloroethane from all of Rocketdyne's Southern California manufacturing operations. ETEC provided DOE with a complete inventory of Class I and Class II ODS's in October 1996.

\subsection{GROUNDWATER}

A groundwater monitoring program has been in place at the SSFL site since 1984 . Currently, the monitoring system includes 243 on-site and off-site wells. There are seven off-site wells, installed by Rocketdyne, near the northwest boundary of Area IV that had been off-site on land acquired by Boeing in 1998. Three wells installed by Rocketdyne remain located off-site northwest of Area IV. The groundwater at SSFL exists in two geologic units. One is the loose and unconsolidated alluvium on bedrock, which is termed the Shallow Zone. The other is the bedrock itself, termed the Chatsworth formation. Groundwater in the Shallow Zone is very seasonal. At many sites the Shallow Zone is dry in the summer. Within Area IV, the Shallow Zone has nine DOE installed wells (excluded E5-31). The Chatsworth formation, composed of indurated and fractured sandstone, constitutes the dominant aquifer underlying Area IV. There are $36 \mathrm{DOE}$ installed wells in and around Area IV.

Routine quarterly chemical and radiological monitoring of the wells is conducted according to the monitoring plan submitted to the lead agency for the groundwater program. Quarterly reports are submitted to the regulatory agencies at the end of the first three quarters. An annual report is submitted after the monitoring for the fourth quarter is completed.

The Shallow Zone is an unconfined system in the alluvium (surface mantle soils) of the Burro Flats area and along the major drainage channels. The alluvium is composed of a heterogeneous mixture of gravel, sand, silt, and clay. Water levels in the alluvium respond to recharge resulting from precipitation and runoff, and may vary considerably between wet and dry periods. 
The Chatsworth formation is composed of consolidated, massively bedded sandstones with interbedded layers of siltstone and claystone.

The formation may be as thick as $6,000 \mathrm{ft}$ at the SSFL site. The regional direction of groundwater flow in the formation is probably radially off-site toward the surrounding lowlands. The permeability of the Chatsworth formation is very low except along open fractures. Groundwater within the fractured Chatsworth formation occurs mostly under confined conditions.

The hydrogeologic environment at the SSFL site is a dynamic system. The groundwater system is recharged by precipitation and infiltration through fractures and from unlined ponds and drainage channels. Because of the meager rainfall in the area and the relatively large variability in annual precipitation, groundwater recharge is generally low and may vary greatly from year to year. Specific pathways of possible transport of contaminant-bearing groundwater along fracture zones are difficult to predict. Fracture zones vary widely in frequency and geometry. Water transmitting characteristics also vary from one location to the other as well as from one specific depth to another. Not all fractures are water bearing. Recharge over the area may also vary over both space and time.

The solvents found in the groundwater include trichloroethylene and its family of degradation products. The analyses results of the Area IV wells have been documented in the "Area IV (Phase III) Groundwater Investigation Report" prepared for Rocketdyne by Groundwater Resources Consultants, Inc., in December 1992 (Ref. 23), as well as in their 1998 Annual Report (Ref. 24).

Three existing areas of TCE contamination in groundwater in the northwest part of Area IV were monitored in 1998. These areas are shown in Figure 6-3, where areas of suspected contamination exceeding $100 \mu \mathrm{g} / \mathrm{L}$ are shown in black, and areas equal to or above $5 \mu \mathrm{g} / \mathrm{L}$ are shown as cross-hatched. The State action level for TCE is $5 \mu \mathrm{g} / \mathrm{L}$. The central occurrence may also extend laterally; however, no data are available because this area is located in inaccessible terrain. The installation of 12 new monitor wells in 1993-1994 did not result in the detection of off-site plumes of degraded groundwater near Area IV.

The Shallow Zone well RS-28, one of the two wells within the TCE occurrence associated with the RMHF canyon (the northern occurrence), recorded 31 to $48 \mu \mathrm{g} / \mathrm{L}$ TCE in 1998 . The other well, a Chatsworth formation well (RD-30) showed $12 \mu \mathrm{g} / \mathrm{L}$ TCE in 1998. Both wells were installed in 1989. RD-34A, a Chatsworth formation well (shallowest well of a three-well cluster constructed in 1991), in the newly acquired land showed 3.6 to $4.8 \mu \mathrm{g} / \mathrm{L} \mathrm{TCE}$ in 1998 , compared to 5.1 to $5.6 \mu \mathrm{g} / \mathrm{L}$ in 1997. RD-63, an extraction well installed in 1994 for the pilot extraction test in the area, recorded 7.2 to $2.0 \mu \mathrm{g} / \mathrm{L} \mathrm{TCE}$ in 1998.

The Chatsworth formation well (RD-7), within the central contaminated area (Figure 6-3) southwest of 4059 , recorded a TCE concentration of 44 to $54 \mu \mathrm{g} / \mathrm{L}$ in 1998 compared to 42 to $53 \mu \mathrm{g} / \mathrm{L}$ in 1997 . Since its construction in 1986, RD-7 generally showed TCE concentrations in the 16 to $54 \mu \mathrm{g} / \mathrm{L}$ range with peaks ranging up to $130 \mu \mathrm{g} / \mathrm{L}$. 
RD-25, located southwest of 4059 , continued to show perchloroethene (PCE). In 1998, the well showed 24 to $35 \mu \mathrm{g} / \mathrm{L}$ PCE, compared to 23 to $28 \mu \mathrm{g} / \mathrm{L}$ PCE in 1997. From 1989 to 1996, the well showed less than 1 to $42 \mu \mathrm{g} / \mathrm{L}$ PCE.

Two Shallow Zone wells (RS-18 and RS-54) of the southern contaminated area (Figure 6-3) near the FSDF at the western end of the site, recorded a significantly high TCE concentrations from 1993 to 1997 . TCE in RS-54 ranged from 1,900 to $4,500 \mu \mathrm{g} / \mathrm{L}$ during the period from 1993 to 1997. In 1998, TCE concentration ranged from 1,500 to $4,500 \mu \mathrm{g} / \mathrm{L}$. RS18 , often dry since its construction in 1985 , recorded TCE at $270 \mu \mathrm{g} / \mathrm{L}$ to $3,200 \mu \mathrm{g} / \mathrm{L}$ in during the period from 1993 to 1997 . RS-18 recorded 130 to $1300 \mu \mathrm{g} / \mathrm{L}$ TCE in 1998 . RD-21 and RD23, two Chatsworth formation wells installed in 1989 at the FSDF, recorded TCE ranging from 88 to $2,400 \mu \mathrm{g} / \mathrm{L}$ during the period from 1993 to 1997 . In 1998, TCE in these wells ranged from 190 to $710 \mu \mathrm{g} / \mathrm{L}$. RD-33A, Chatsworth formation well (shallowest well of a three-well cluster constructed in 1991), showed 3.6 to $9.8 \mu \mathrm{g} / \mathrm{L}$ TCE in 1998 , compared to 2.4 to $9.7 \mu \mathrm{g} / \mathrm{L}$ in the period from 1993 to 1997 . RD-65, a Chatsworth formation well located northeast of the FSDF showed 480 to $550 \mu \mathrm{g} / \mathrm{L} \mathrm{TCE}$ in 1998. TCE in the well was between 67 and $610 \mu \mathrm{g} / \mathrm{L}$ in 1997 .

The pilot extraction test at RMHF included installation of an extraction well and treatment of the extracted water in a portable carbon adsorption treatment unit. Results indicated that groundwater extraction in the test well at RMHF was effective in creating a capture zone for degraded groundwater. The capture zone extended up to $200 \mathrm{ft}$ down gradient of the extraction well. Two new wells were installed for the pilot test at the FSDF. Cyclic pumping of one to three wells was conducted in the test at this site, an area characterized by low yield of groundwater. Extraction and treatment of contaminated groundwater continued on an interim basis at RMHF and the FSDF in 1998. Groundwater from both sites is treated by liquid-phase carbon adsorption and is released southward to the surface water collection system. The activity at the FSDF was initiated in 1994 and at the RMHF in 1997. 


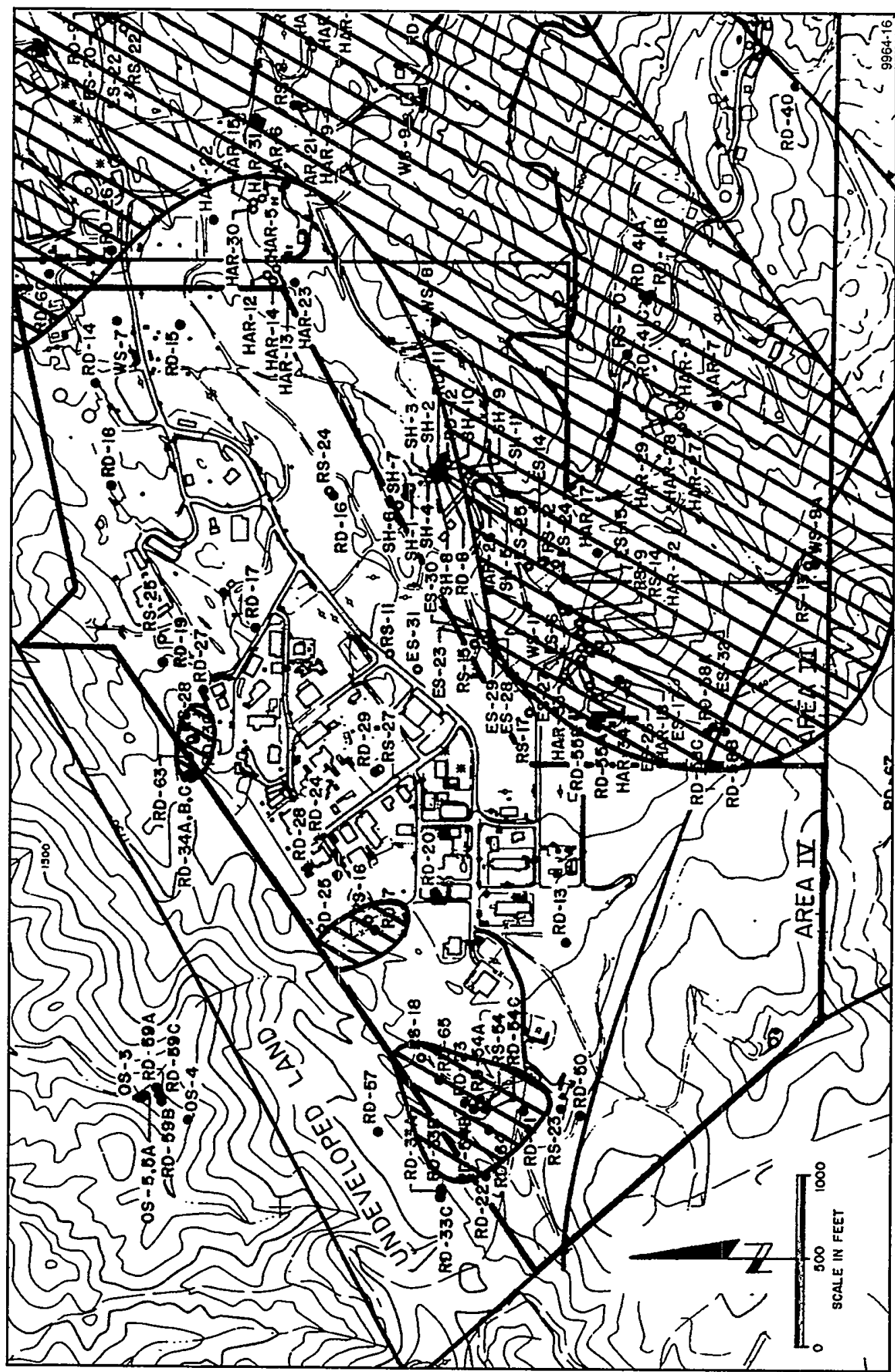

Figure 6-3. TCE Occurrences in Groundwater at SSFL, Area IV (exceeding 5 ppb) 


\section{ENVIRONMENTAL MONITORING PROGRAM QUALITY CONTROL}

This section describes the quality assurance (QA) elements incorporated into the Rocketdyne radiological analysis program that ensure data produced are as meaningful as possible.

The following elements of quality control are used for the Rocketdyne program:

1. Reagent Quality-Certified grade counting gas is used.

2. Laboratory Ventilation-Room air supply is controlled to minimize temperature variance and dust incursion.

3. Laboratory Contamination-Periodic laboratory contamination surveys for fixed and removable surface contamination are performed. Areas are cleaned routinely and decontaminated when necessary.

4. Control Charts-Background and reference source control charts for counting equipment are maintained to evaluate stability and response characteristics.

5. Laboratory Intercomparisons-Rocketdyne participates in the DOE EML-QAP.

6. Calibration Standards-Counting standard radioactivity values are traceable to NIST primary standards.

7. Co-location of State DHS thermoluminescent dosimeters.

\subsection{PROCEDURES}

Procedures followed include those for selection, collection, packaging, shipping, and handling of samples for off-site analysis; sample preparation and analysis; the use of radioactive reference standards; calibration methods and instrument QA; and data evaluation and reporting.

\subsection{RECORDS}

Records generally cover the following processes: field sample collection and laboratory identification coding; sample preparation method; radioactivity measurements (counting) of samples, instrument backgrounds, and analytical blanks; and data reduction and verification.

Quality control records for laboratory counting systems include the results of measurements of radioactive check sources, calibration sources, backgrounds, and blanks, as well as a complete record of all maintenance and service.

Records relating to overall laboratory performance include the results of analysis of interlaboratory cross-check samples and other quality control analyses; use of standard (radioactive) reference sources; and calibration of analytical balances. 


\subsection{QUALITY ASSURANCE}

Rocketdyne participates in the DOE Quality Assessment Program (QAP) operated by the Environmental Measurements Laboratory (EML) in New York for radiological analyses. During 1998, two sets of samples were distributed: QAP-XLVIII and QAP-XLIX (Refs. 25 and 26). In 1994, EML analyzed the QAP historical data for air filter, soil, vegetation, and water samples from 1982 through 1992 to generate representative control limits for the performance evaluation of analytical services. The individual data values reported by the participating laboratories were normalized to the EML reference value, and the normalized values were grouped into percentiles. The middle $70 \%$ of all historical reported values (from the 15 th to 85 th percentile) was established as Acceptable and the next $10 \%$ on both sides of the $70 \%$ - the 5 th to 15 th and 85th to 95th percentiles - as acceptable with Warning. Results outside this $90 \%$ band were considered not acceptable.

Rocketdyne and DOE use several laboratories for environmental sample analyses. Results of Rocketdyne, California DHS Sanitation and Radiation Laboratory, Oak Ridge Institute for Science and Education (ORISE), Teledyne-Brown Engineering Environmental Services, Thermo Nutech Oak Ridge Laboratory, and the average for all laboratories analyses, are shown in Figure 7-1 for QAP-XLVIII and QAP-XLIX. (Some DHS results for QAP-XLVIII were not reported in the program documents.) Although these comparisons involve sample types, geometries, and analyses that are not part of the routine procedures at the Rocketdyne laboratory, historical review of the Rocketdyne results and those of the other laboratories has generally shown a similar level of quality.

The QAP soil and vegetation samples (200 g and $100 \mathrm{~g}$, respectively) are significantly smaller than the typical $600 \mathrm{~g}$ sample size used at Rocketdyne for similar analyses. In 1996, Rocketdyne succeeded in modifying the small amounts of soil, vegetation, and water samples provided by the EML so that geometric effects had negligible impact on the analytical results. In 1997, Rocketdyne improved the air sample results over previous analyses. In 1998, the Rocketdyne air sample results for QAP-XLVIII were low. Note, however, that Rocketdyne conducts no quantitative air filter analyses for environmental use. In-house air filter analyses are qualitative and for investigative reasons concerning the identification of the isotope. All quantitative environmental air samples for the site are analyzed by outside laboratories. For the present report, soil samples and air and effluent filter samples were analyzed by Teledyne-Brown Engineering Environmental Services (Westwood, NJ), surface water samples were analyzed by Barringer Labs, and groundwater samples were analyzed by Thermo Nutech. 

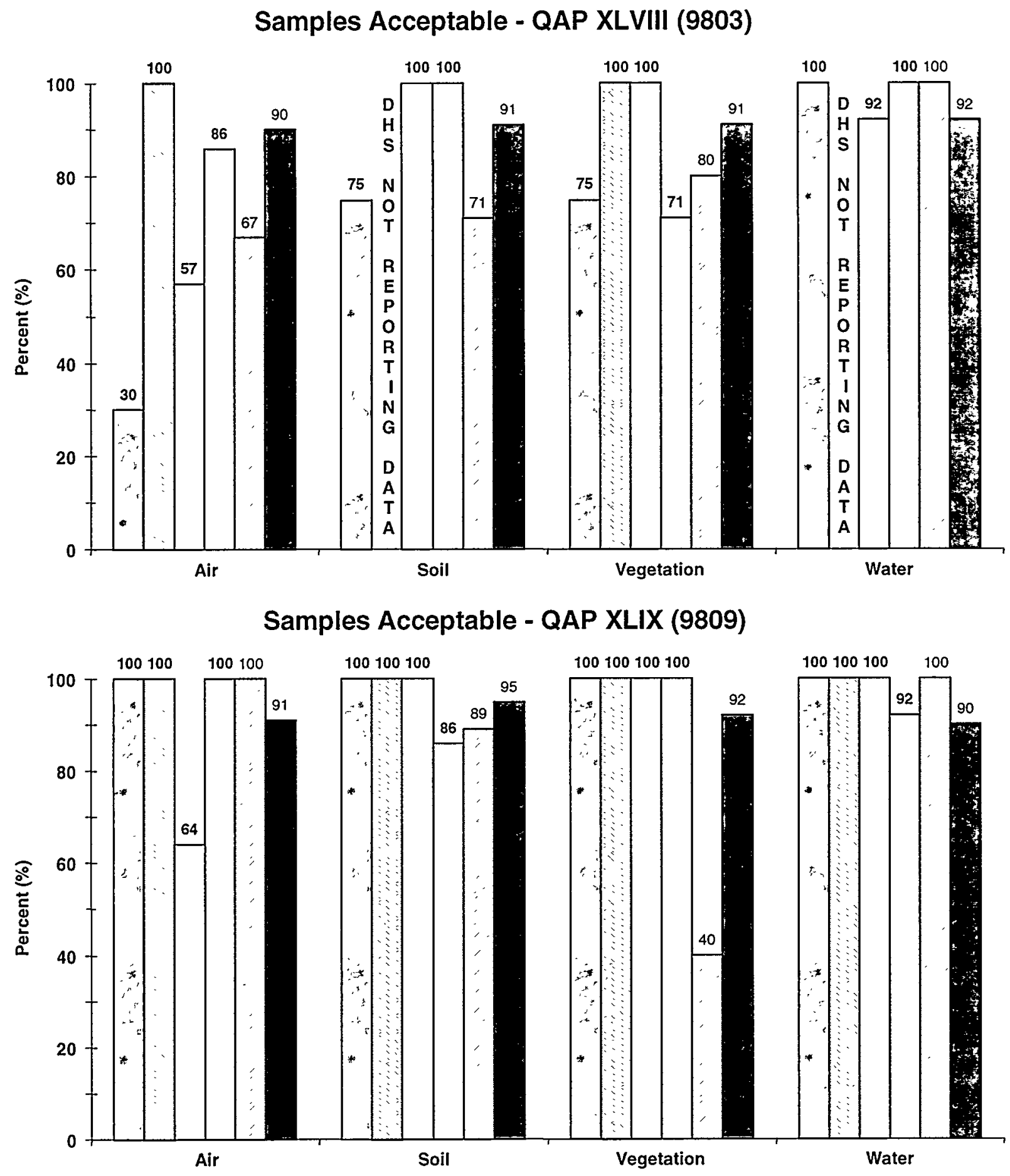

$\square$ Rocketdyne $\square$ California DHS $\square$ oRISE $\square$ Teledyne-Brown $\square$ Thermo Nutech

9964-17

Figure 7-1. Quality Assessment Program Results for QAP-XLVI and QAP-XLVII 
RD99-115

This page intentionally left blank 


\section{REFERENCES}

1. R. D. Oldenkamp and J. C. Mills, "Nuclear Operations at Rockwell's Santa Susana Field Laboratory - A Factual Perspective," Rockwell Document N001ER000017, Rev. C, September 1991.

1. F. C. Dahl, "Post-Remediation Ambient Gamma Radiological Survey of the Former Sodium Disposal Facility (T886)," Rockwell Document 886-ZR-0007, December 1994.

2. R. J. Tuttle, "Post-Remediation Soil Sampling and Analysis for the Former Sodium Disposal Facility," Rockwell Document 886-ZR-0009, January 1997.

3. P. M. Liddy, "Final Status Survey Report of Area 4064," Boeing Document (R21-RF) RS 00003, February 1999.

4. B. M. Oliver, "Final Radiological Survey Report for Building T012," Rockwell Document 012-AR-0002, June 1996.

5. A. L. Pascolla, "Decontamination and Decommissioning of Building T012," Rockwell Document 012-AR-0001, May 1997.

6. T. J. Vitkus and J. R. Morton, "Verification Survey of Building T012, Santa Susana Field laboratory, Rockwell International, Ventura County, California," ORISE 96-0860, October 1996.

7. V. C. Chaney, "Final Radiological Survey Report for Building T363," Rockwell Document SSWA-AR-0002, June 1996.

8. T. J. Vitkus and J. R. Morton, "Verification Survey of Building T363, Santa Susana Field Laboratory, Rockwell International, Ventura County, California," ORISE 96-0870, October 1996.

9. E. R. McGinnis, "Final Radiological Survey Report for Building T030," Boeing Document 030-AR-0001, January 1997.

10. T. J. Vitkus and T. L. Bright, "Final Report, Verification Survey of the Interim Storage Facility; Buildings T030, T641, and T013; an Area Northwest of Buildings T019, T013, T012, and T059; and a Storage Yard West of Buildings T626 and T038, Santa Susana Field Laboratory, Rockwell International, Ventura County, California," ORISE 96/C-4, February 1996

11. F. C. Dahl and R. J. Tuttle, "Final Radiological Survey Report of Building 023," Rockwell Document, 023-ZR-0001, March 1994.

12. P. Waite, "Building 023 D\&D Operations Final Report," Rockwell Document, 023-AR0002, September 1993. 
RD99-115

13. T. J. Vitkus, "Verification Survey of Buildings 005, 023, and 064, Santa Susana Field Laboratory, Rockwell International, Ventura County, California," ORISE 94/K-14, October 1994.

14. T. J. Vitkus, "Interim Letter Report for the Phase 2 Verification Survey of the Land Formerly Supporting the Hot Laboratory, Santa Susana Laboratory, Canoga Park, California," January 1999

15. P. M. Liddy, "De Soto Building 104, Mass Spectroscopy Laboratory, Final Status Survey Report," Boeing Document N001SRR140129, October 1998.

16. T. J. Vitkus, "Verification Survey of the De Soto Mass Spectroscopy Laboratory (Building 104)," ORISE Draft Report, March 1999.

17. Users Guide for CAP88-PC, Version 1, EPA/520/6-91-022, December 1991

18. DOE Order 5400.1, “General Environmental Protection Program Requirements,” February 2, 1990.

19. DOE Order 5400.5, "Radiation Protection of the Public and the Environment," (2/8/90), Change $1(6 / 5 / 90)$, Change $2(1 / 7 / 93)$.

20. R. Atkinson, "ETEC Waste Minimization and Pollution Prevention Awareness Plan," ETEC Document GEN-AN-0037, Rev. A, September 1996.

21. C. Yu et al., "Manual for Implementing Residual Radioactive Material Guidelines Using RESRAD, Version 5.0,” ANL/EAD/LD-2, September 1993.

22. Groundwater Resources Consultants, Inc. "Area IV Groundwater Investigation Report," December 1992.

23. Groundwater Resources Consultants, Inc., "Annual Groundwater Monitoring Report, Santa Susana Field Laboratory, 1998," Tucson, Arizona, February 24, 1999.

24. EML-596, "Semi-Annual Report of the Department of Energy, Office of Environmental Management, Quality Assessment Program," USDOE Report, July 1, 1998.

25. EML-600, "Semi-Annual Report of the Department of Energy, Office of Environmental Management, Quality Assessment Program," USDOE Report, December 1998. 


\section{APPENDIX A \\ ACRONYMS}

AI

ALARA

ANI

ANL

AOC

ASL

BOD

CAA

CCR

CERCLA

CFR

CRWQCB

CWA

CX

$D \& D$

DCG

DHS/RHB

DOE

DTSC

EA

ECL

EIS

EM

EML

EP

EPA

ER

ETEC

ETS

FFCA

FONSI

FSDF

GIF

GRC HEPA
Atomics International

As Low As Reasonably Achievable

American Nuclear Insurers

Argonne National Laboratory

Areas of Concern

Above Sea Level

Biological Oxygen Demand

Clean Air Act

California Code of Regulations

Comprehensive Environmental Response, Compensation, and Liability Act

Code of Federal Regulations

California Regional Water Quality Control Board

Clean Water Act

Categorical Exclusion

Decontamination and Decommissioning

Derived Concentration Guide

Department of Health Services/Radiologic Health Branch

Department of Energy

Cal-EPA Department of Toxic Substances Control

Environmental Assessment

Effluent Concentration Limit

Environmental Impact Statement

Environmental Management

Environmental Measurements Laboratory

Environmental Protection

Environmental Protection Agency

Environmental Remediation

Energy Technology Engineering Center

Extraction and Treatment Center

Federal Facilities Compliance Act

Finding of No Significant Impact

Former Sodium Disposal Facility

Gamma Irradiation Facility

Groundwater Resources Consultants, Inc. (Tucson, AZ)

High-Efficiency Particulate Air 
Hot Lab

HPGe

HWMF

LAFD

LARWQCB

LLD

LLTR

LLW

LMDL

MARSSIM

MCA

$\mathrm{MCL}$

MDA

MLLW

ND

NEPA

NM

NESHAPS

NIOSH

NIST

NOI

NOV

NPDES

NRC

NSPS

NTU

ODS

ORISE

$\mathrm{PA} / \mathrm{SI}$

PCB

PCE

PNNL

QA

QAP

RA

R\&D

RCRA

RFA
Hot Laboratory (Bldg. 4020)

High-Purity Germanium (Detector)

Hazardous Waste Management Facility

Los Angeles Fire Department

Los Angeles Regional Water Quality Control Board

Lower Limit of Detection

Large Leak Test Rig (4059)

Low Level Waste

Liquid Metal Development Laboratory

Multi-Agency Radiation Survey and Site Investigation Manual

Multichannel Analyzer

Maximum Contamination Level

Minimum Detectable Activity

Mixed Low Level Waste

Not Detected

National Environmental Policy Act

Not Measured

National Emission Standards for Hazardous Air Pollutants

National Institute of Occupational Safety and Health

National Institute of Standards and Technology

Notice of Intent

Notice of Violation

National Pollutant Discharge Elimination System

Nuclear Regulatory Commission

New Source Performance Standards

Nephelometric Turbidity Units

Ozone Depleting Substance

Oak Ridge Institute for Science and Education

Preliminary Assessment/Site Investigation

Polychlorinated Piphenyl

Perchloroethene

Pacific Northwest National Laboratory

Quality Assurance

Quality Assessment Program

Radioactive

Research and Development

Resource Conservation and Recovery Act

RCRA Facility Assessment 


$\begin{array}{ll}\text { RFI } & \text { RCRA Facility Investigation } \\ \text { RMHF } & \text { Radioactive Materials Handling Facility } \\ \text { ROD } & \text { Record of Decision } \\ \text { RPT } & \text { Reaction Products Tank } \\ \text { RS } & \text { Radiation Safety } \\ \text { SARA } & \text { Superfund Amendments and Reauthorization Act } \\ \text { SCAQMD } & \text { Southern California Air Quality Management District } \\ \text { SCTL } & \text { Small Component Test Loop } \\ \text { SHEA } & \text { Safety, Health \& Environmental Affairs } \\ \text { S\&M } & \text { Surveillance and Maintenance } \\ \text { SNAP } & \text { Systems for Nuclear Auxiliary Power } \\ \text { SNM } & \text { Special Nuclear Materials } \\ \text { SPCC } & \text { Spill Prevention Control and Countermeasure } \\ \text { SRAM } & \text { Standardized Risk Assessment Methodology } \\ \text { SRE } & \text { Sodium Reactor Experiment } \\ \text { SSFL } & \text { Santa Susana Field Laboratory } \\ \text { SWPPP } & \text { Storm Water Pollution Prevention Plan } \\ \text { STP } & \text { Sewage Treatment Plant or Site Treatment Plan } \\ \text { SWMU } & \text { Solid Waste Management Unit } \\ \text { TCE } & \text { Trichloroethylene } \\ \text { TLD } & \text { Thermoluminescent Dosimeter } \\ \text { TSDF } & \text { Treatment, Storage, and Disposal Facility } \\ \text { TUc } & \text { Toxic Units Chronic } \\ \text { UCLA } & \text { University of California, Los Angeles } \\ \text { UST } & \text { Underground Storage Tank } \\ \text { VCAPCD } & \text { Ventura County Air Pollution Control District } \\ \text { VCEHD } & \text { Ventura County Environmental Health Division } \\ \text { VOC } & \text { Volatile Organic Compound } \\ \text { WVN } & \text { Water Vapor Nitrogen } \\ & \end{array}$


RD99-115

This page intentionally left blank.

0399964.doc 


\section{DISTRIBUTION}

(single enclosure unless otherwise noted)

U.S. Department of Energy

Office of Scientific and Technical Information

P.O. Box 62

Oak Ridge, TN 37831

M. Lopez (4 copies)

U.S. Department of Energy

Oakland Operations Office

1301 Clay Street, Suite 700-N

Oakland, CA 94612

U.S. Department of Energy

Environmental Measurements Lab

201 Varick Street, Fifth Floor

New York, NY 10014-4811

Steve Black (8 copies)

U.S. Department of Energy

Oakland Operations Office

1301 Clay Street, Suite 700-N

Oakland, CA 94612

County of Ventura

Fire Protection District

Hazardous Material Section

395 Willis Avenue

Camarillo, CA 93010

County of Ventura

Resource Management Agency

Ventura, CA 93009

Ventura County Board of Supervisors

800 South Victoria Blvd:

Ventura, CA 93009

Richard Lesler

U.S. Environmental Protection Agency

Region 9

75 Hawthorne Street

San Francisco, CA 94105
Tom Kelly

U.S. Environmental Protection Agency

Region 9

75 Hawthorne Street

San Francisco, CA 94105

Gregg Dempsey

Center for Environmental Restoration, Monitoring and Emergency Response

U.S. Environmental Protection Agency

944 E. Harmon Street

Post Office Box 98517

Las Vegas, NV 89193

Ed Bailey

California State Department of Health

Services

Radiologic Health Branch

714 "P" Street

Sacramento, CA 95201

Paul Baldenweg

California State Department of Health Services

Radiological Health Branch

1449 West Temple Street, Room 209

Los Angeles, CA 90026

California State Department of Health Services

Environmental Health Investigation Branch

1515 Clay Street, $17^{\text {th }}$ floor

Oakland, CA 94612

Gerard Abrams

California Environmental Protection Agency

Department of Toxic Substances Control

Region 1

Facility Permitting Branch

10151 Croydon Way, Suite 3

Sacramento, CA 95827-2106 
RD99-115

Jim Ross

California Regional Water Quality Control

Board

Los Angeles Region

101 Centre Plaza Drive

Monterey Park, CA 91754-2156

Los Angeles County Health Department

Occupational Health and Radiation

Management

Los Angeles, CA 90007

U.S. Nuclear Regulatory Commission

Office for Analysis and Evaluation of

Operational Data

Washington, DC 20555

Richard Turtil

Low Level Waste \& Decommissioning

Division of Waste Management

Office of Nuclear Material Safety \&

Safeguards

U.S. Nuclear Regulatory Commission

Washington, DC 20555-0001

Paul Fox

American Nuclear Insurers

Town Center, Suite 3005

29 Main Street

West Hartford, CT 06107-2445

City Manager of Simi Valley

2929 Tapo Canyon Road

Simi Valley, CA 93063

California State University, Northridge

Attn: Robert Marshall

Urban Archives Center

Oviatt Library - Basement, Room 4

18111 Nordhoff Street

Northridge, CA 91330

Simi Valley Public Library

Attention: Ms. Janet Weaver

2969 Tapo Canyon Road

Simi Valley, CA 93063
Platt Branch Library

Attn: Ms. Janet Metzler

23600 Victory Blvd.

Woodland Hills, CA 91367

The Honorable Cathie Wright

California State Assembly

District 37

250 Easy Street, Suite 7

Simi Valley, CA 93063

The Honorable Elton Gallegly

United States House of Representatives

$21^{\text {st }}$ District

9301 Oakdale Avenue \#110

Chatsworth, CA 91311

Dan Hirsch

Committee to Bridge the Gap

1637 Butler Street

Los Angeles. CA 90027

Sheldon Plotkin

3318 Culbert Avenue

Los Angeles, CA 90066

Barbara Johnson

6714 Clear Spring Road

Simi Valley, CA 93063

Jerome Raskin

18350 Los Alimos Street

Northridge, CA 91326

Santa Monica Mountains Conservancy

Authority

Attn: Rorie Skei

3750 Solstice Canyon Road

Malibu, CA 90265

Arthur Pinchev

Brandeis-Bardin Institute

1101 Pepper Tree Lane

Simi Valley, CA 93064 